UNIVERSIDADE DE SÃO PAULO

Faculdade de Educação

OS OBJETOS NOS MUSEUS DE CIÊNCIAS:

o papel dos modelos pedagógicos na aprendizagem

Ana Maria Senac Figueroa

São Paulo

2012 
Ana Maria Senac Figueroa

\section{OS OBJETOS NOS MUSEUS DE CIÊNCIAS: \\ o papel dos modelos pedagógicos na aprendizagem}

Tese apresentada à Faculdade de Educação

da Universidade de São Paulo, como requisito para a obtenção do título de Doutora em Educação.

Área de Concentração: Ensino de Ciências e Matemática

Orientadora: Prof ${ }^{\mathrm{a}}{ }^{-}{ }^{\mathrm{a}}$ - Martha Marandino 


\section{OS OBJETOS NOS MUSEUS DE CIÊNCIAS: o papel dos modelos pedagógicos na aprendizagem}

Tese apresentada à Faculdade de Educação da Universidade de São Paulo, como requisito para a obtenção do título de Doutora em Educação.

Área de Concentração: Ensino de Ciências e Matemática

Prof $^{\mathrm{a}} \mathrm{Dr}^{\mathrm{a}} \mathrm{a}$ Martha Marandino (Orientador) - USP

Prof. Dr.

Prof. Dr.

Prof. Dr.

Prof. Dr.

São Paulo, 2012. 
Para Izabela, filha querida, com todo o meu amor... 


\section{AGRADECIMENTOS}

Gostaria aqui de expressar meus agradecimentos às pessoas e instituições, familiares e amigos, que não só compartilharam comigo a elaboração desta tese, como efetivamente contribuíram para que ela pudesse ser realizada. A lista, por certo, é enorme e é bem capaz de alguns nomes ficarem fora dela. Peço desculpas se isso ocorrer. Assim, gostaria de iniciar agradecendo ao CNPq pela bolsa de pesquisa concedida nos dois últimos anos de elaboração da tese.

À Prof ${ }^{\mathrm{a}}$. Dr ${ }^{\mathrm{a}}$ Martha Marandino, pela orientação, estímulo e muita paciência na elaboração da pesquisa e pelas oportunidades acadêmicas que me proporcionou. Me recebeu em seu grupo com o coração aberto e enfrentou desafios comigo e por mim. Aprendi com ela a nunca desistir, a ser ética e responsável e que a nossa união e parceria vão além dos muros da academia. Um parágrafo é muito pouco para expressar a minha admiração, gratidão e amizade.

Aos demais professores e alunos da Faculdade de Educação da Universidade de São Paulo, pela vivência em um ambiente rico, sério e profissional de pesquisa e ensino. Agradeço também à Profa ${ }^{\text {. }}$ Dr ${ }^{\mathrm{a}}$ Silvia Trivelatto e ao Prof. Dr. Ronaldo Luiz Nagem pelas contribuições importantes ao projeto de qualificação.

Ao Prof. Dr. Ronaldo Luiz Nagem, especialmente, coloco a "culpa" por esse doutorado se concretizar - uma brincadeira entre nós. Desde a graduação, sempre se mostrou amigo e companheiro, preocupado com a trajetória de seus alunos. Aprendi com ele a ter serenidade ao tratar assuntos conflituosos e a respeitar as 
dificuldades das pessoas que fazem parte da nossa convivência diária. Ao lado desse grande homem tem uma mulher, também especialmente importante, Maria Helena Nagem, a quem expresso também a minha admiração.

Ao falar do Prof. Dr. Ronaldo Nagem, não posso deixar de agradecer a todos os integrantes do Grupo de Estudo de Metáforas, Modelos e Analogias na Tecnologia na Educação e na Ciência (GEMATEC). A esse grupo que me acolhe até hoje, meus sinceros agradecimentos. Em especial, gostaria de agradecer às minhas amigas/irmãs Cinthia Gomes, Eliene Freire e Sônia Coelho pelo carinho, parceria, estímulo e desabafos nas horas difíceis.

Aos colegas do Grupo de Estudo e Pesquisa em Educação Não Formal e Divulgação em Ciência (GEENF), meus mais sinceros agradecimentos pelas contribuições acadêmicas, e ainda, pela amizade e carinho. Às amigas Cynthia e Tânia, Carla Gruzman pelo carinho e estímulo nesses anos que vivi em São Paulo.

À amiga Rose, por todos os cafés compartilhados e por toda a ajuda e carinho que me deu em São Paulo.

À amiga Inês, pelas conversas via telefone, meu carinho e gratidão.

Votos especiais de agradecimentos aos profissionais do Museu de Ciências Naturais da Pontifícia Universidade Católica de Minas Gerais (PUC-Minas), que disponibilizaram tempo e conhecimentos sem os quais esta pesquisa não poderia ser feita. Meus agradecimentos especiais ao Bruno e Ana Cristina.

Agradeço, ainda, à diretora e aos funcionários da Escola Estadual Professor Leon Renault e ao pessoal da Secretaria de Estado da Educação do Estado de 
Minas Gerais, que me proporcionaram tempo hábil e oportunidades para a realização desse doutorado.

Finalmente, à minha família, pela presença constante, amizade sem fim, suporte emocional nos momentos difíceis, pelo amor, por tudo. À Neide, mãe, pelo incentivo e amor, ao Juan, pai querido, que se estivesse aqui estaria muito orgulhoso. Às minhas irmãs muito amadas, Mari e Néli, pelo carinho, amor e compreensão nos dias difíceis. Ao meu sobrinho e afilhado Marcelo, exemplo de jovem responsável e carinhoso.

Ao Sergio, pela paciência em todos os momentos.

E, à pessoinha mais importante de toda a minha vida, pela ausência, paciência com as mudanças de humor, cobranças, e que sei, tem muito orgulho de mim, minha maravilhosa filha, IZABELA. 
ESTA É A “MOCINHA” QUE NOS INSPIROU...

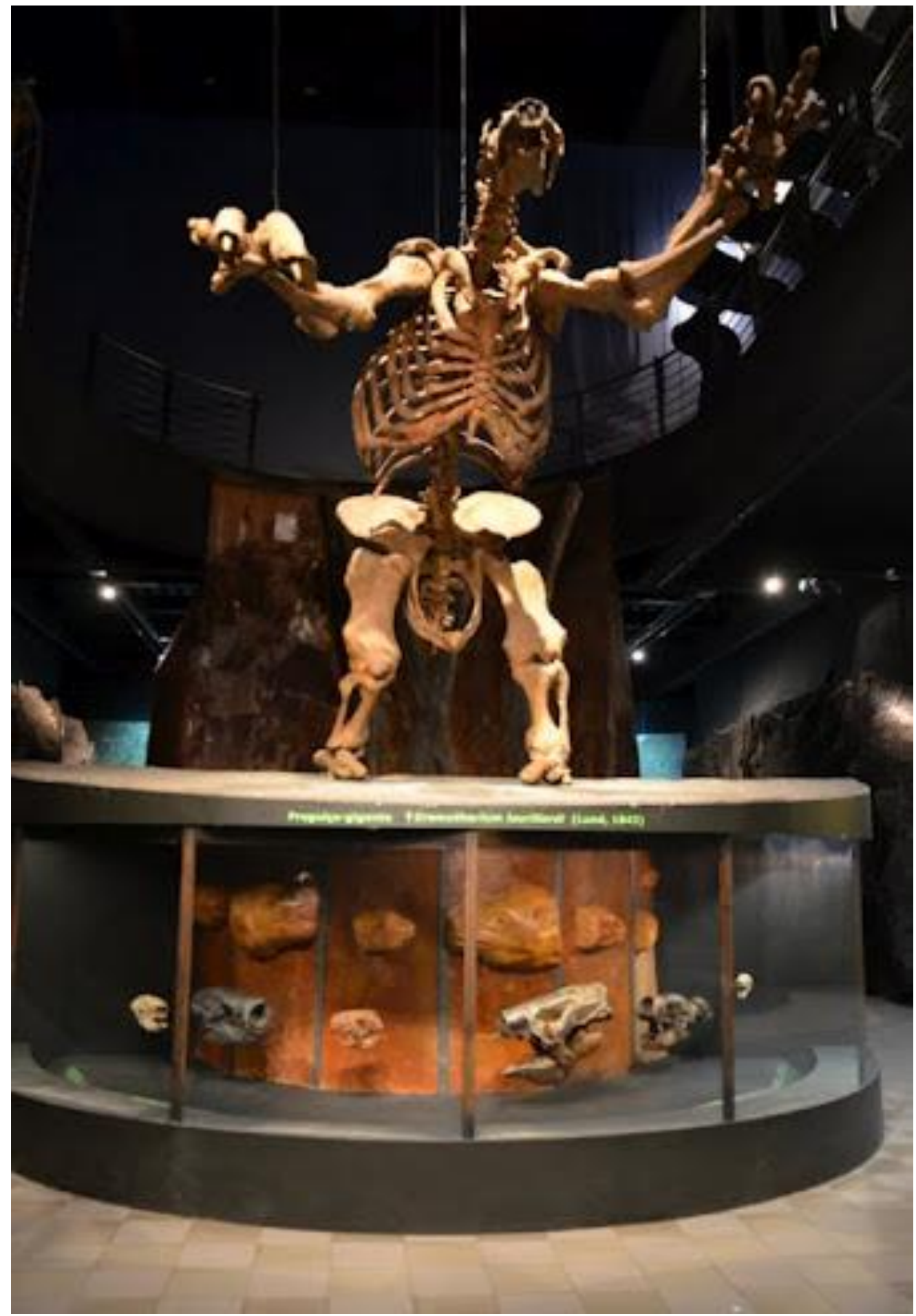




\section{RESUMO}

FIGUEROA, A. M. S. Os Objetos nos Museus de Ciências: o papel dos modelos pedagógicos na aprendizagem. 2012. 199p. Tese (Doutorado em Educação) Faculdade de Educação da Universidade de São Paulo, São Paulo, 2012.

Esta pesquisa teve por objetivo caracterizar o papel pedagógico dos objetos/modelos nos museus de ciências. Assim, consideramos, neste estudo, os objetos no museu que foram construídos com a intenção de favorecer as relações de ensino e de aprendizagem. Buscamos apontar o papel pedagógico dos objetos em exposições de museus, bem como caracterizar o potencial do objeto em expressar determinados produtos e processos na aprendizagem, ao ser apresentado em uma exposição de museu. Além disso, procuramos identificar aspectos relacionados aos conceitos e processos que os sujeitos são capazes de perceber, ao observar o objeto em uma exposição. A abordagem metodológica se fundamentou no referencial da pesquisa qualitativa e foi selecionado o Museu de Ciências Naturais da Pontifícia Universidade Católica de Minas Gerais. A escolha do modelo do esqueleto da preguiça gigante se justificou por tratar do objeto que, pelo seu tamanho e posição expográfica chama especialmente a atenção do público. Além disso, ele tem um papel importante no desenvolvimento de estudos de biologia e de paleontologia, bem como reúne uma gama muito grande de características importantes, o que o tornou adequado para a pesquisa. Selecionamos para a entrevista, o profissional do museu, responsável pela produção dos modelos e um dos elaboradores da exposição. Os cinco jovens convidados a participar desse estudo tinham, na época, 17 anos de idade e cursavam o $2^{\circ}$ ano do ensino médio, em escolas privadas, localizadas na cidade de Belo Horizonte, Minas Gerais. Julgamos que a opção por jovens de um mesmo nível de escolaridade, com afinidades sociais semelhantes e que estabeleciam uma relação de amizade facilitaria a interação social, tornando a visita mais fluida e natural. Tomamos como referência os conceitos de "aprendizagem em museus" explicitados por alguns autores como George Hein, Falk e Dierking, Hooper-Greenhill e Scott Paris. Ainda para a fundamentação teórica da pesquisa, optamos por referenciais teóricos relativos às áreas da educação e de objetos/modelos nos museus, especialmente nos museus de ciências. Para a coleta dos dados da pesquisa, combinamos o uso de múltiplas fontes, com a finalidade de obter as informações necessárias tanto em relação às intenções do objeto pedagógico, ou seja, o modelo do esqueleto da preguiça gigante, exposto no museu escolhido, quanto às interações dos jovens em relação a esse mesmo objeto. Para a coleta de dados com os jovens, a pesquisa contou com três etapas: antes, durante e após a visita ao museu. As etapas foram gravadas em vídeo e áudio, incluindo as entrevistas. Com base nos resultados obtidos, articulamos os dados oriundos do conjunto do "nosso olhar" e do "olhar do museu" e analisamos esses dados a partir dos dois eixos relacionados às dimensões da aprendizagem: o conceitual e o processual. Analisamos, também, as interações de cada jovem com o objeto pedagógico e todo o conjunto expositivo, a partir desses eixos da aprendizagem. Percebemos que as intenções do modelo pedagógico 
foram, em sua maioria, compreendidas pelos jovens visitantes. Evidenciamos essas intenções a partir dos elementos que compõem os eixos analisados. As interações com os objetos nos museus promovem a possibilidade de realizar observação e descrição, de expressar conhecimento prévio, de promover discussão, criação e testagem de hipóteses. Instigam, ainda, a imaginação e a elaboração de questões. No entanto, no que se refere à formação correta de conceitos científicos, pensar a forma de apresentar os objetos, os textos e as imagens nos museus é fundamental.

Palavras-chave: Educação em museus. Objetos pedagógicos. Aprendizagem em museus. Educação não formal. Museus de ciências. 


\begin{abstract}
FIGUEROA, A. M. S. The objects in science museums: the role of pedagogical models in learning. 2012. Thesis (PhD in Education) - Education Faculty, São Paulo University, São Paulo, Brazil, 2012.

This study aimed to characterize the educational role of the objects / models in science museums. Thus, we consider in this study, the objects in the museum that were built with the intention of promoting relations of teaching and learning. We seek to point out the educational role of objects in museum exhibitions, as well as to characterize the potential of the object in expressing certain products and processes in learning to be presented in a museum exhibit. In addition, we sought to identify aspects related to the concepts and processes that subjects are able to perceive when observing the object in an exhibition. The methodological approach was based on the framework of qualitative research and was selected the Museum of Natural Sciences at the Catholic University of Minas Gerais. The choice of model of the skeleton of a giant sloth was because it is the object that by its size and position expographic draws the most attention. Moreover, it has an important role in the development of Biology and Paleontology studies, as well as meeting a wide range of important features, which made it suitable for this research. Museum professionals responsible for the production of models and makers of the exhibition were selected for interview. The five young people invited to participate in this study were 17 years old and currently enrolled in 2nd year of high school of a private school located in the city of Belo Horizonte, Minas Gerais, Brasil. We believe that choosing young people with the same level of schooling and affinities, of similar social levels and setting up friendship, ease social interaction, making the visit more fluid and natural. We took as reference the concepts of "learning in museums", by some authors such as George Hein, Falk and Dierking, Hooper-Greenhill and Scott Paris. Even for theoretical research, we chose fields related to education and objects / models in museums, especially in science museums. To collect the survey data, we combine the use of multiple sources, in order to obtain the necessary information regarding both the pedagogical intentions of the object, i.e. the model of the skeleton of the giant sloth, exhibited in the museum chosen as the interaction of young people in relation to this same object. For data collection with young people the survey had three stages: before, during and after the museum visit. The steps were recorded on video and audio, including interviews. Based on these results, we articulated the data from the whole "our eyes" and "look of the museum" and analyzed this data from the two axes related to the dimensions of learning, the conceptual axis and the axis of procedure. We also analyze the interactions of each youth, with the object and the whole pedagogic exhibition, from learning these axes. We realize that the intentions of the pedagogical model were understood by mostly young visitors which evidence, from the elements that make up the axis of conceptual and procedural learning analyzed. The interactions with objects in museums promote the possibility of observation, description and express prior knowledge, to promote discussion, development and testing of hypotheses. They also promote imagination, prompting questions.
\end{abstract}


However, with regard to the proper formation of scientific concepts, to think how to present the object, the texts and images in museums are fundamental.

Keywords: Museums education. Pedagogical objects. Learning in museums. Non formal education. Science museums. 


\section{LISTA DE FIGURAS}

FIGURA 1: Museu de Ciências Naturais da PUC-Minas....................................78

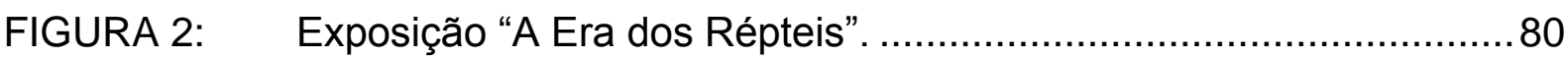

FIGURA 3: $\quad$ Exposição "Peter W. Lund: Memórias de um Naturalista" ..................81

FIGURA 4: Exposição Cavernas: Espaços Subterrâneos de Vida ......................82

FIGURA 5: Exposição "O Cerrado". .............................................................. 83

FIGURA 6: Exposição: A Grande Extinção: 11 mil anos ....................................84

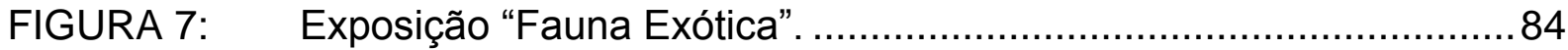

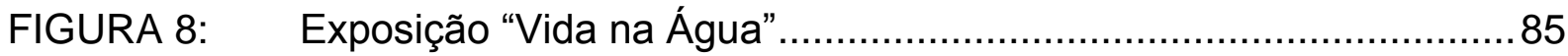

FIGURA 9: Reconstituição da preguiça gigante pintada no painel.......................88

FIGURA 10: Modelo do esqueleto da preguiça gigante. .................................102

FIGURA 11: Legenda: Preguiça gigante - Eremotherium laurillardi (Lund,

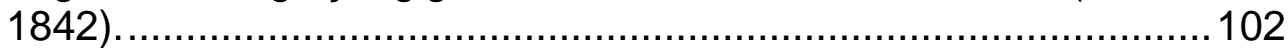

FIGURA 12: Legenda e vitrine com fósseis originais e reconstituições da

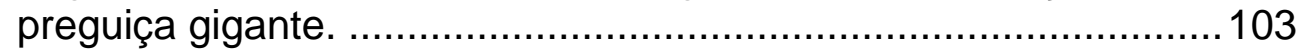

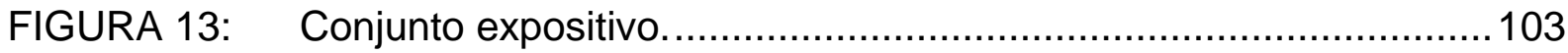

FIGURA 14: Crânio original da preguiça gigante .............................................104

FIGURA 15: Crânio original da preguiça gigante. ........................................104

FIGURA 16: Reconstituição da mão da preguiça gigante. ................................105

FIGURA 17: Reconstituição da preguiça terrícola, extinta há mais de 10 mil

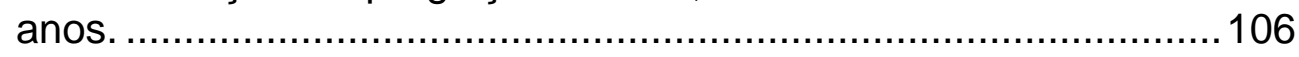

FIGURA 18: Painel pintado que reconstitui o ambiente em que viveu a preguiça gigante. …..................................................................106

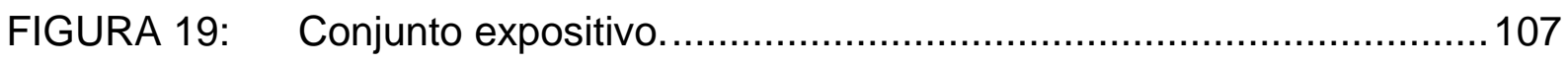

FIGURA 20: Texto pertencente ao conjunto expositivo....................................107

FIGURA 21: Texto pertencente ao conjunto expositivo....................................108 
FIGURA 22: Texto pertencente ao conjunto expositivo...................................108

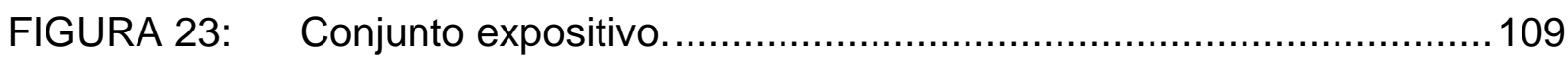

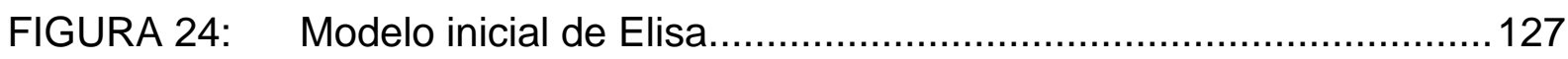

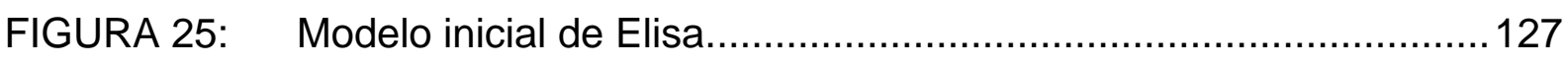

FIGURA 26: Modelo inicial de João............................................................128

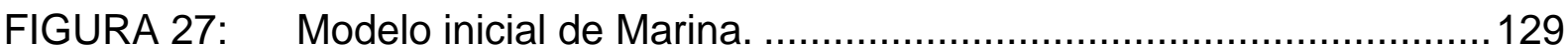

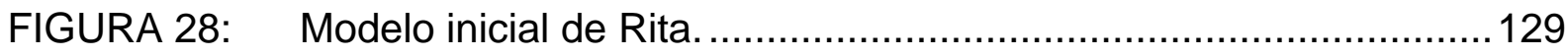

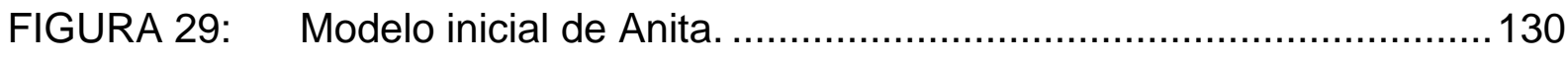

FIGURA 30: Modelo final de Elisa........................................................137

FIGURA 31: Modelo final de João ............................................................138

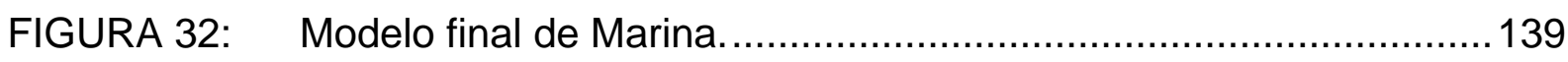

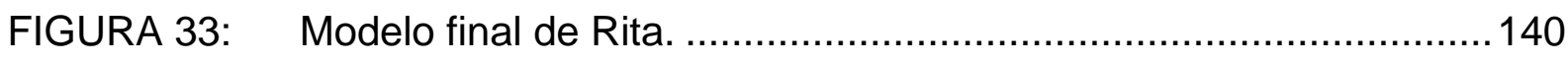

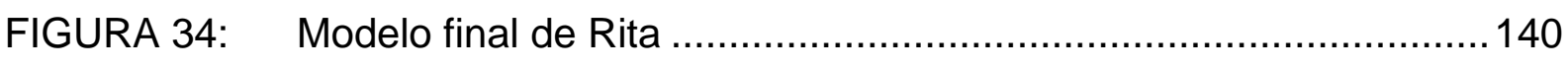

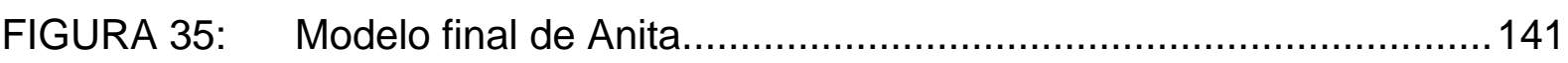




\section{LISTA DE SIGLAS E ABREVIATURAS}

GEENF Grupo de Estudos em Educação Não Formal

GEMATEC Grupo de Estudo de Metáforas, Modelos e Analogias na Tecnologia na Educação e na Ciência ().

ICOFOM International Committee for Museology

PUC-Minas Pontifícia Universidade Católica de Minas Gerais 


\section{SUMÁRIO}

$1 \quad$ INTRODUÇÃO

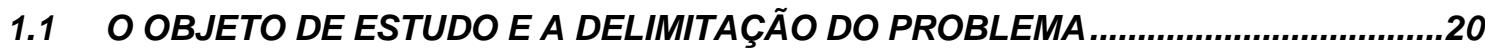

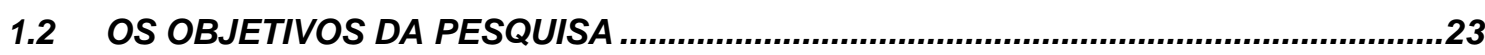

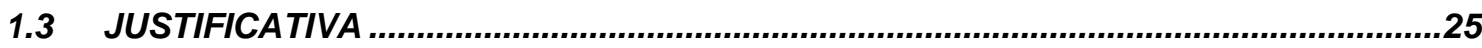

2 MUSEUS, EDUCAÇÃO E APRENDIZAGEM ..........................................................

2.1 OS MUSEUS COMO ESPAÇOS DE EDUCAÇÃO

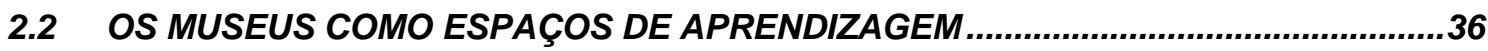

$3 \quad$ OS OBJETOS NOS MUSEUS DE CIÊNCIAS ..........................................................45

3.1 OS MODELOS PEDAGÓGICOS E SUAS RELAÇÕES COM A EDUCAÇÃO.................53

3.2 OS MODELOS PEDAGÓGICOS E SUAS RELAÇÕES COM A APRENDIZAGEM ........65

$4 \quad$ METODOLOGIA DA PESQUISA

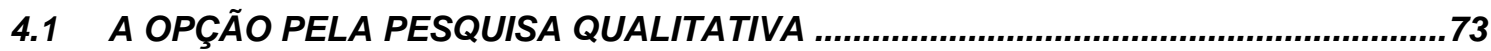

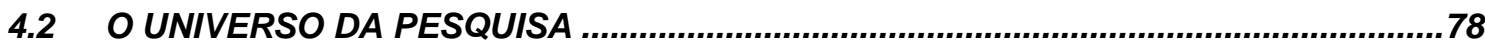

4.2.1 O Museu de Ciências Naturais da PUC-Minas ..................................................

4.2.2 O objeto pedagógico: o modelo do esqueleto da preguiça gigante ........................86

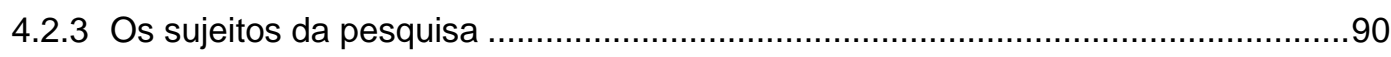

4.3 INSTRUMENTOS DE COLETA DE DADOS E AS ETAPAS DA PESQUISA COM

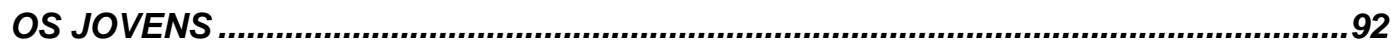

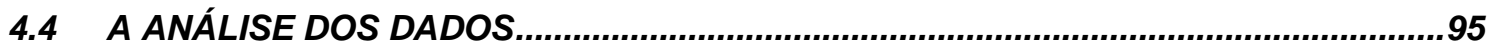

$5 \quad$ AS INTENÇÕES DO MODELO E AS INTERAÇÕES DOS JOVENS .........................100

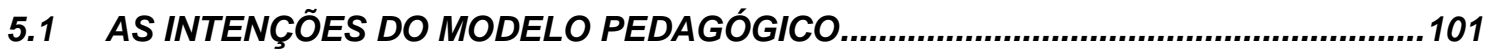

5.1.1 O Objeto Pedagógico e o Conjunto Expositivo: nosso olhar ...............................101

5.1.2 O esqueleto da preguiça gigante: o olhar do museu ...........................................109

5.2 AS INTERAÇÕES DOS JOVENS COM O MODELO DO ESQUELETO DA PREGUIÇA GIGANTE........................................................................................120

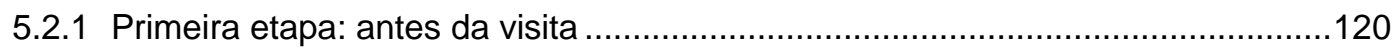

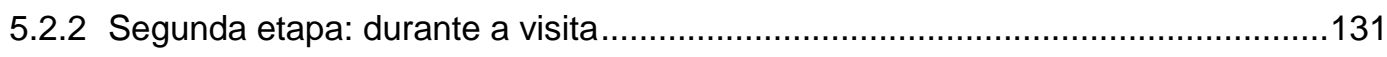

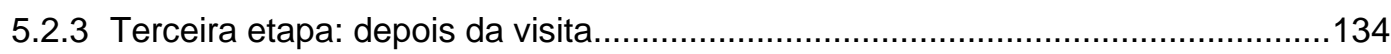

6 DAS INTENÇÕES DO MODELO ÀS INTERAÇÕES DOS JOVENS..........................144

6.1 ANÁLISE DAS INTENÇÕES: NOSSO OLHAR E O OLHAR DO MUSEU SOBRE O OBJETO 


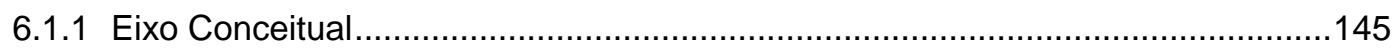

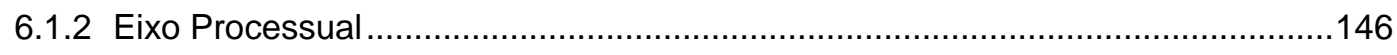

6.2 ANÁLISE DAS INTERAÇÕES DOS JOVENS COM O OBJETO: ANTES,

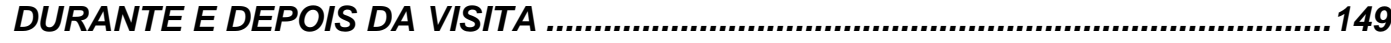

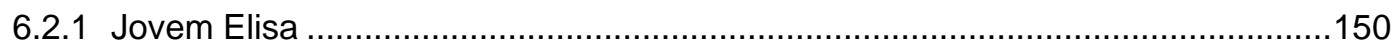

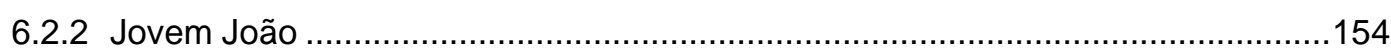

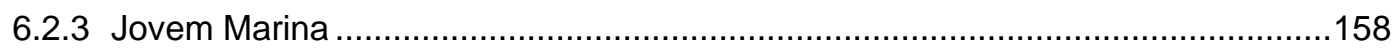

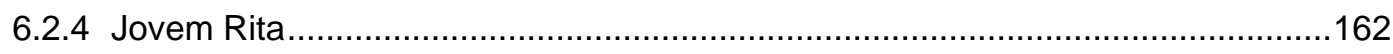

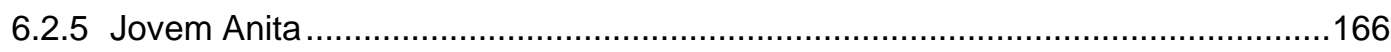

6.3 CONFRONTANDO AS INTENÇÕES DO MODELO PEDAGÓGICO COM AS INTERAÇÕES DOS JOVENS: ALGUMAS CONSIDERAÇÕES .............................168

REFERÊNCIAS BIBLIOGRÁFICAS ......................................................................179

APÊNDICE A - ROTEIRO DA ENTREVISTA COM O RESPONSÁVEL PELA CONFECÇÃO E EXPOSIÇÃO DO ESQUELETO DA PREGUIÇA GIGANTE ...........188

APÊNDICE B - ENTREVISTA COM OS JOVENS ANTES DA VISITA AO Museu de Ciências Naturais DA PUC-MINAS.....................................................................191

APÊNDICE C - CONSTRUINDO O MODELO DO ESQUELETO DA PREGUIÇA GIGANTE - PRÉ-VISITA .....................................................................................194

APÊNDICE D - QUESTÕES UTILIZADAS PELA PESQUISADORA DURANTE A VISITA AO MUSEU, COM OS ALUNOS FRENTE AO OBJETO ESCOLHIDO O ESQUELETO DA PREGUIÇA GIGANTE

APÊNDICE E - ENTREVISTA PÓS-VISITA AO MUSEU DA PUC-MINAS COM OS JOVENS 
INTRODUÇÃO 


\section{INTRODUÇÃO}

Nos dias de hoje, a importância dos museus de ciências naturais como espaço educativo é evidente. Há um crescente aumento das pesquisas nessa área, bem como um interesse cada vez maior do público visitante. Tal fato faz desses museus ambientes que podem contribuir para a melhoria da qualidade do ensino e da aprendizagem em ciências.

Nesse sentido, torna-se cada vez mais importante uma reflexão acerca das concepções de aprendizagem e de educação em locais como os museus de ciências naturais. A educação em museus possui especificidades as quais são ressaltadas por diferentes autores como George Hein, John Falk, Lynn Dierking, Van-Präet e Poucet, e elementos como espaço, tempo e objetos são considerados fatores importantes que irão constituir o diferencial da educação nesses espaços.

Os ambientes de educação não formal são tão importantes que Dewey (1900) usou o museu como sendo "o coração físico e metafórico da escola ideal". Ele viu o museu como um local onde as experiências das crianças entram em contato com ferramentas e práticas "todas importantes para interpretar e expandir experiências". Ele estava especialmente interessado no papel dos objetos, não apenas para instigar a imaginação, mas também na construção do conhecimento (ROWE, 2002).

Van Präet e Poucet (1989) destacam a importância dos objetos para caracterizar o discurso museal, sendo estes fontes de riqueza e de interatividade. A função de coletar, preservar, pesquisar e expor objetos está na essência das 
instituições museais e, por essa razão, os objetos são a base de comunicação entre museu e público (BELCHER, 1992; DEAN, 1994).

Em 2002, Scott Paris edita um livro em que vários autores ressaltam a importância da aprendizagem centrada em objetos nos museus e assume que a compreensão das interações entre objetos e visitantes é uma tarefa difícil, porém fascinante.

Dessa forma, para Colinvaux (2005), a experiência museal é definida como a vivência no espaço-tempo de um museu por aqueles que o visitam, qualquer que seja o tempo de duração da visita. Para a autora, é relevante lembrar que a experiência museal não ocorre no vazio, mas sim em um contexto institucional específico: é a instituição, por meio de seus profissionais, que, a partir de um propósito, uma intencionalidade, uma missão, irá conceber, realizar e propor atividades variadas para um público amplo. Todavia, a experiência em um museu é, sobretudo, daquele que visita o espaço: o visitante. Portanto, se, por um lado, é proveitoso investigar intenções, objetivos e modos de realização dessas instituições e das equipes envolvidas com a concepção e organização das diversas atividades oferecidas pelos museus, é necessário, por outro lado, examinar a experiência museal a partir da perspectiva do visitante, ou seja, daqueles que, em última análise, legitimam e referendam as propostas a eles oferecidas (COLINVAUX, 2005, p. 1).

Assim, considerando os museus espaços de ensino e aprendizagem e levando em conta a importância dos objetos nesse processo, é que gostaríamos de situar este trabalho e, para tal, escolhemos desenvolvê-lo no Museu de Ciências Naturais da Pontifícia Universidade Católica de Minas Gerais (PUC-Minas), situado na cidade de Belo Horizonte, Minas Gerais. 
No museu escolhido, há uma grande quantidade de modelos/réplicas de ossos e esqueletos, que são produzidos a partir dos originais. Assim, para este estudo, selecionamos o modelo do esqueleto da preguiça gigante existente na exposição, por se tratar de um objeto que reúne uma série de características importantes para nossa investigação. O tamanho e a maneira com que está exposto o objeto, simulando seu comportamento no ambiente natural, chamam a atenção do público. Além disso, a preguiça gigante é de grande importância para o desenvolvimento dos estudos em biologia e paleontologia. Dessa forma, encerra uma gama muito grande de conceitos científicos, além de processos de produção da ciência, o que o torna relevante e instigante do ponto de vista da aprendizagem em museus.

\subsection{O OBJETO DE ESTUDO E A DELIMITAÇÃO DO PROBLEMA}

$\mathrm{Na}$ abordagem que considera a aprendizagem como mudanças na maneira de ver, pensar, atuar e perceber o mundo sustenta-se a ideia de que é um processo contínuo, que acontece em todo lugar, que começa no indivíduo, mas envolve outros. É um processo que acontece também fora da escola, por meio de uma aprendizagem de livre escolha, guiado pelos interesses próprios e pelas necessidades dos sujeitos, sendo ainda condicionada pelos conhecimentos prévios dos indivíduos (MURRIELLO, 2009).

A partir da década de 1970, começou a aparecer na literatura estudos específicos com os conteúdos das ideias dos estudantes em relação aos variados conceitos científicos aprendidos na escola. Essas pesquisas surgiram como um 
Ana Maria Senac Figueroa

OS OBJETOS NOS MUSEUS DE CIÊNCIAS:

o papel dos modelos pedagógicos na aprendizagem

desdobramento crítico àquelas realizadas por Piaget e colaboradores. Elas são fruto de uma preocupação específica com o ensino dessas noções, presentes nesses trabalhos e ausentes nos de Piaget. Driver e Easley (1978), num artigo considerado como um marco desse movimento, criticavam a excessiva ênfase ao desenvolvimento de estruturas lógicas subjacentes, o que teria levado Piaget a não dar importância à rica variedade de ideias apresentadas pelas crianças. Isso levava os autores a sugerirem que "poderia ser útil a realização de uma série de replicações dos estudos que focalizassem mais o conteúdo atual das ideias dos alunos e menos as estruturas lógicas subjacentes" (MORTIMER, 1996). Os resultados desses estudos contribuíram para fortalecer uma visão construtivista de ensino e de aprendizagem que, até muito recentemente, parecia dominar a área de Educação em Ciências e Matemática (MATTHEWS ${ }^{1}, 1992$ apud MORTIMER, 1996).

Apesar da grande variedade de diferentes abordagens e visões, que aparecem na literatura sob o mesmo rótulo, há pelo menos duas características principais que parecem ser compartilhadas:

1) A aprendizagem se dá através do ativo envolvimento do aprendiz na construção do conhecimento.

2) As ideias prévias dos estudantes desempenham um papel importante no processo de aprendizagem (MORTIMER,1996).

Em nossa trajetória acadêmica e profissional, a preocupação com a aprendizagem por meio de modelos pedagógicos, levando-se em consideração as

1 MATTHEWS, M. R. Constructivism and empiricism: an incomplete divorce. Review of Educational Research, v. 22, p. 299-307, 1992. 
ideias prévias dos estudantes, se fazia presente e suscitava questões importantes como, por exemplo:

a. Por que utilizar modelos pedagógicos para explicar conceitos científicos?

b. Qual a potencialidade desses modelos na re-elaboração das ideias iniciais dos jovens?

c. As visitas aos museus de ciências e a interação com objetos/modelos, que foram construídos para ensinar e para aprender, garantem a promoção da aprendizagem?

Abordamos este tema na pesquisa de mestrado cujo objeto de estudo foi verificar a potencialidade de um modelo pedagógico, análogo ao real, denominado "café com leite", e que tinha como objetivo explorar o conceito de incompatibilidade sanguínea, ou seja, o grupo $A B O$. Na referida pesquisa, os alunos foram capazes de estabelecer relações entre o modelo apresentado e o sistema $A B O$, visto que eles conseguiram, em sua maioria, estabelecer conexões entre o alvo (conceito de incompatibilidade sanguínea - sistema $A B O$ ) e o veículo (o modelo "café com leite").

Dessa forma, surgiu a necessidade e o interesse em pesquisar o referido tema, em outros espaços de aprendizagem, ou seja, os espaços não formais de educação, em particular os museus de ciências.

Para tal, o doutorado na Faculdade de Educação da Universidade de São Paulo propiciou-nos a busca pela compreensão do tema "modelos/objetos pedagógicos" na aprendizagem, como também suscitou questões essenciais para esse estudo tais como: 
1. Qual a influência do modelo pedagógico do museu na aprendizagem?

2. Até que ponto as intenções de um modelo pedagógico são incorporadas nos modelos produzidos pelos jovens?

Essas questões foram importantes não só para compor os objetivos gerais e os objetivos específicos dessa pesquisa, mas também para a construção de todo o nosso estudo.

\subsection{OS OBJETIVOS DA PESQUISA}

A presente pesquisa visa caracterizar o papel pedagógico dos objetos/modelos nos museus de ciências. Assim, consideramos, neste estudo, os objetos no museu que foram construídos com a intenção de favorecer as relações de ensino e de aprendizagem. Desse modo, são os objetivos gerais da pesquisa:

- Apontar o papel pedagógico dos objetos em exposições de museus.

- Caracterizar o potencial do objeto em expressar determinados produtos e processos na aprendizagem, ao ser apresentado em uma exposição de museu.

- Identificar aspectos relacionados aos conceitos e processos que os sujeitos são capazes de perceber, ao observar o objeto em uma exposição.

Para a fundamentação da pesquisa, optamos por referenciais teóricos relativos às áreas da educação, da aprendizagem e de objetos/modelos nos museus, especialmente nos museus de ciências. 
Nesse caminho, direcionamos o estudo para o objeto no museu como um modelo potencialmente pedagógico, visto que ele é parte fundamental de um conjunto importante na exposição como um todo, bem como, no museu estudado.

Assim sendo, buscamos compreender como e com que intenções o modelo escolhido para a pesquisa, o modelo do esqueleto da preguiça gigante, foi elaborado e colocado na exposição do museu selecionado, o Museu de Ciências Naturais da PUC-Minas, buscando caracterizar os diferentes elementos, como produtos, processos e contextos que favorecem a aprendizagem.

Em relação ao estudo dos produtos e processo de aprendizagem dos jovens envolvidos durante a observação do esqueleto da preguiça gigante, as discussões das interações entre o objeto/modelo pedagógico estudado e as possíveis aprendizagens construídas a partir das ideias iniciais dos referidos jovens, bem como das intenções do objeto, tomamos como referência os conceitos de "aprendizagem em museus" explicitados por alguns autores como Hein (1998), Falk e Dierking (2000), Hooper-Greenhill (1999) e Scott Paris (2002).

Para a compreensão do processo de interação dos jovens com o modelo do esqueleto da preguiça gigante e de todo o conjunto expositivo em que o modelo se insere, buscamos:

- Levantar as intenções do museu ao expor o objeto na exposição.

- Levantar as ideias que os sujeitos selecionados possuíam acerca do objeto antes da observação do mesmo no museu.

- Analisar as falas dos sujeitos durante a interação com o objeto na exposição. 
- Analisar as interpretações do objeto realizadas pelos sujeitos após a visita ao museu.

As etapas acima indicadas foram construídas a partir de atividades elaboradas e executadas antes, durante e depois da visita com os jovens no museu.

\subsection{JUSTIFICATIVA}

A pertinência do tema aqui proposto se explica por diversas razões, quais sejam: a importância dos objetos nos museus de ciências, o papel central desses objetos na relação ensino e aprendizagem e a análise das construções das ideias de jovens visitantes frente ao objeto escolhido para este estudo.

Já o termo "objeto pedagógico" é um interessante foco de investigação visto que, segundo Marandino (2001), os objetos são elementos caros aos museus e são antigas as discussões sobre sua importância, o seu papel e as suas características. Além disso, com o desenvolvimento de novas tecnologias no campo da comunicação, a importância dos objetos nos museus tornou-se tema de grandes debates, principalmente com as experiências dos museus virtuais e com a introdução dos objetos interativos e participativos nas exposições (MARANDINO, 2001).

Nesse estudo em particular, optamos por tratar como sinônimos os termos "objeto pedagógico" e "modelo pedagógico", por entendermos que o esqueleto da preguiça gigante foi construído a partir do fóssil original e com a intenção de ensinar e de propiciar a aprendizagem de conceitos científicos. Portanto, esse trabalho se 
Ana Maria Senac Figueroa

OS OBJETOS NOS MUSEUS DE CIÊNCIAS:

o papel dos modelos pedagógicos na aprendizagem

justifica pela importância em se caracterizar o papel pedagógico dos modelos/objetos nos museus de ciências, na perspectiva da aprendizagem de jovens estudantes.

Para Hooper-Greenhill (1994a), o papel educacional dos museus deve ser analisado na perspectiva do visitante, das suas concepções, da sua agenda, de seus conhecimentos e interesses. Para isso, um dos instrumentos é compreender o processo de interpretação dos visitantes nos museus e, nesse sentido, a autora explicita os procedimentos para o desenvolvimento de análise do processo, os quais devem considerar as especificidades do local, especialmente quanto aos objetos que possuem. Ressalta, ainda, que o processo de aprendizagem nesses espaços é frequentemente centrado nos objetos e que o "diálogo" entre estes e o observador pode ter diferentes formas e penetrar num espectro variado de campos.

Já Colinvaux (2005) ressalta que, na maioria das vezes, partimos da proposição comumente aceita de que o visitante aborda e tira proveito da experiência da visita aos museus, com base em sua bagagem de conhecimentos prévios, mas que é necessário ampliar essa discussão. Para essa autora, não se trata, por certo, de negar a bagagem conceitual - conhecimentos prévios, noções espontâneas - ricamente documentada desde o final da década de 1970, ensejando amplo movimento construtivista na educação em ciências e farta literatura de pesquisa. Trata-se de problematizar e avançar em nossa concepção de visitante, buscando uma melhor caracterização de sua bagagem prévia.

A autora citada acima entende que a bagagem prévia dos visitantes inclui também perguntas, dúvidas, questionamentos, que são determinantes da riqueza da experiência museal, ou seja, dos modos de ação, interação e interrogação de cada 
Ana Maria Senac Figueroa

OS OBJETOS NOS MUSEUS DE CIÊNCIAS:

o papel dos modelos pedagógicos na aprendizagem

visitante em seu percurso e diálogo pelos espaços de um museu. Assim, por um lado, as ações do indivíduo são norteadas pela bagagem de perguntas e interrogações que traz em sua visita ao museu. Por outro, a perspectiva do visitante, em sua interação com os elementos de uma exposição, é condicionada pelo contexto específico de cada exposição. Confirma-se que interações parecem estar no cerne da experiência museal (COLINVAUX, 2005).

Dessa forma, no que se refere às teorias de comunicação aplicadas ao contexto de museu, Hoper-Greenhill (1994a) afirma que o sentido do objeto na exposição é condicionado pela relação que ele estabelece com os outros objetos e com os recursos utilizados, através de etiquetas e textos, para auxiliar na interpretação pelo visitante.

Já Moya (1998) acentua que as coleções são as principais ferramentas dos museus, nas quais se baseiam as exposições e os programas educativos. Elas incluem os objetos de importância "estética, histórica, educativa ou científica". No caso específico dos museus de ciências, a autora aponta que "as coleções têm a função didática de comunicar ao visitante o espírito e a mentalidade dos cientistas a fim de promover sua inclinação natural pela ciência". Além disso, as coleções devem também "responder a uma guia conceitual que coincida com os objetivos do museu e necessidades da comunidade".

Para o desenvolvimento desse estudo, optamos por uma metodologia pautada na abordagem qualitativa, já que procuramos compreender o objeto em si, seu papel na exposição como um modelo pedagógico e as implicações desse modelo pedagógico na aprendizagem dos jovens. 
No capítulo 02, "Museus, educação e aprendizagem", apresentamos um panorama relativo ao tema da educação e da aprendizagem nesses espaços de educação não formal, bem como a importância das exposições e seus objetos na promoção da educação e da aprendizagem em museus.

No capítulo 03, "Os objetos nos museus de ciências", apresentamos os modelos pedagógicos e suas relações com a educação e com a aprendizagem, como também, assumimos o termo modelo pedagógico para designar os objetos que foram construídos com a intenção de ensino e de aprendizagem. Apresentamos, ainda, uma revisão da literatura, acerca do termo modelo pedagógico.

O capítulo 04, que trata da "Metodologia da Pesquisa", encerra a descrição dos procedimentos de coleta de dados, incluindo aqueles referentes às informações sobre o modelo pedagógico e de todo o conjunto expositivo, e as etapas da pesquisa junto aos jovens selecionados para esse estudo.

Apresentaremos, ainda, nesse capítulo, a descrição da análise dos dados coletados. Essa descrição propõe explicitar o que estamos chamando de "intenção da exposição" e de "interação dos jovens com o modelo", na perspectiva de aspectos conceituais e de aspectos museográficos de todo o conjunto expositivo em que está inserido o modelo do esqueleto da preguiça gigante.

No capítulo 05, "As intenções do modelo pedagógico e as interações dos jovens", descreveremos as intenções do modelo pedagógico do esqueleto da preguiça gigante e do conjunto expositivo, segundo as nossas observações. Em seguida, apresentaremos as intenções da exposição de acordo com o responsável pela sua elaboração. Por fim, reuniremos os dados referentes às construções dos 
modelos dos jovens em consonância com as falas dos mesmos acerca do modelo estudado, ou seja, as interações entre os jovens e o modelo pedagógico escolhido para esse estudo.

De acordo com as categorias levantadas no capítulo 04 , juntamente com os dados descritos nesse capítulo, realizaremos as articulações possíveis desses dados coletados com a teoria estudada.

No último capítulo, "Das intenções do objeto pedagógico às interações dos jovens", relataremos os significados que a pesquisa apontou para as relações das intenções do objeto pedagógico e do conjunto expositivo com as possíveis interações dos jovens com esse mesmo objeto, visando caracterizar o papel pedagógico dos modelos.

Indicaremos, ainda, possíveis contribuições que a pesquisa aponta em direção à melhoria do ensino e da aprendizagem em ciências e suas relações com os modelos pedagógicos nos museus de ciências. 
MUSEUS, EDUCAÇÃO E APRENDIZAGEM 


\section{MUSEUS, EDUCAÇÃO E APRENDIZAGEM}

Os museus são, por natureza, instituições que detêm a evidência material, objetos e espécimes, da história humana e natural do nosso planeta. São instituições permanentes, sem fins lucrativos, que adquirem, preservam, documentam, pesquisam e comunicam para educação e lazer (PEARCE, 1992). Se, por um lado, a dimensão educacional desses espaços está expressa em sua definição atual, o seu papel educacional vem sendo assumido progressivamente e se acentuou no século XX.

Nesse sentido, os museus de ciências têm sido cada vez mais consagrados como locais fundamentais para o desenvolvimento da educação não formal em ciências. As atividades educativas, desenvolvidas nesses espaços, são de diferentes naturezas e estratégias variadas têm sido propostas para realizá-las.

A educação em museus possui especificidades as quais vêm sendo ressaltadas por diferentes autores (PEARCE, 1992; VAN-PRÄET, 2003; HEIN, 1998; FALK; DIERKING, 2002; PARIS, 2002; MARANDINO, 2001) e elementos como espaço, tempo e objetos são considerados alguns dos fatores que irão constituir o diferencial da educação nesses espaços.

Para Almeida (1997), as exposições museológicas são discursos criados com intenção de comunicar ideias, conceitos e informações ao público visitante, tendo como veículo específico os objetos. A ação educativa em museus visa ampliar as possibilidades de aproveitamento pedagógico dos acervos, para que o visitante 
possa acentuar seu espírito crítico em relação a sua realidade e daqueles que estão à sua volta.

Assim, ao considerarmos que os museus são espaços propícios para a educação, assumimos, também, que nesses locais é possível ocorrer a aprendizagem e que o caráter pedagógico dos objetos é um elemento fundamental deste processo (BIZERRA, 2009; PARIS, 2002; LEINHARDT, 2002; HEIN, 1998; FALK; DIERKING, 1992). Mas como esse processo é levado a cabo nesses locais? Qual a natureza da aprendizagem que ocorre em visitas a museus de ciências? Qual o papel dos objetos expostos na aprendizagem de conceitos e processos científicos nos museus? Nessa pesquisa, buscamos fornecer elementos para responder a tais questões e para tal iremos, a seguir, aprofundar aspectos sobre a dimensão educacional dos museus fundamentados na literatura sobre os museus como espaços de educação e de aprendizagem.

\subsection{OS MUSEUS COMO ESPAÇOS DE EDUCAÇÃO}

Os museus de história natural são os herdeiros das "salas de curiosidades", abertas ao público durante o século XVI, em vários cantos da Europa, com o objetivo do mostrar as coleções daqueles que se interessavam pelo estudo do mundo natural a um público conhecedor e motivado para se cultivar. Com o evoluir dos quatro ramos da ciência, que classicamente fazem parte de um museu de história natural zoologia, botânica, geologia e antropologia -, estes passaram, ao longo dos séculos XVI e XVII, a ser o local do trabalho de especialistas (BURCAW, 1983). Essa ênfase na investigação com base nas coleções se altera ao longo dos períodos posteriores. 
No século XIX se delineia de forma mais intensa a dimensão educacional dessas instituições, na medida em que diferentes públicos passam a ter acesso aos espaços expositivos e que os museus iniciam ações voltadas para seus visitantes. Para Burcaw (1983), ao longo dos períodos indicados, delinearam-se as três funções que atualmente se consideram como essenciais de qualquer museu: aquisição e conservação de coleções, investigação e divulgação (funções educativas).

Atualmente os museus são reconhecidos como locais que possibilitam intensa interação social entre os visitantes, exploração ativa e ricas experiências afetivas, culturais e cognitivas (BEETLESTONE et al., 1998). Para os autores, as possibilidades culturais e didáticas desses espaços, aliadas às políticas governamentais de fomento e valorização do patrimônio, e a políticas educacionais de formação profissional, têm ajudado a compor um panorama em que os museus são parceiros da instituição escolar, além de representar uma importante opção de educação fora do espaço escolar (HEIN, 1998; DIERKING, 2005).

Os museus são espaços culturais e educativos. Para Pereira et al. (2007), pretendem educar por meio da sensibilização e cultivam a comunicação e produção de significados, a partir de seus objetos, exposições e propostas educativas.

Ao longo dos anos, tanto a pesquisa quanto as práticas educacionais relacionadas às exposições, bem como às atividades em museus têm se intensificado, tornando-se cada vez mais um campo de produção do conhecimento. Para Marandino (2001), os museus se caracterizam como espaços de produção, educação e divulgação do conhecimento. Não obstante, para ela, a relação dos museus com as escolas configurou-se, ao longo dos anos, de forma quase 
"permanente", o que faz com que esse público seja prioritário em muitas instituições museais.

Leinhardt (2002) considera que os museus são, em primeira instância, entidades sociais e culturais complexas. São entidades culturais porque se organizam como espaços de sentido, onde se reúnem e preservam os exemplos das realizações artísticas, científicas e sociais da humanidade, e entidades sociais porque o colecionador, o conservador, o educador e o designer empreendem diálogos, ora tácitos, ora explícitos, com os visitantes.

No que cabe às instituições escolares, sobretudo a partir dos anos 1980, Nascimento (2005) e Marandino (2005) constatam que tem aumentado o reconhecimento da importância dos espaços e instituições culturais nos processos educacionais. Pesquisas desenvolvidas em ambientes não formais de aprendizagem vêm demonstrando as potencialidades que os museus possuem para promover uma educação integral e continuada às populações e esforços estão sendo feitos para abarcar um maior número de pessoas para visitarem esses espaços.

Assim, entendemos que o museu pode ser um espaço para o exercício da autonomia, por exemplo, quando as visitas se realizam em família, sendo estes momentos uma ocasião única para o desenvolvimento de comportamentos intrinsecamente motivados, a partir do jogo e das interações sociais positivas. Por estas razões, os grupos de crianças e jovens não devem ser apenas vistos como futuros visitantes dos museus. Na realidade, eles já são membros da comunidade, com todas as especificidades de um visitante em potencial. 
Ana Maria Senac Figueroa

OS OBJETOS NOS MUSEUS DE CIÊNCIAS:

o papel dos modelos pedagógicos na aprendizagem

Hooper-Greenhill (1994b) aponta duas abordagens importantes para compreensão da educação desenvolvida nos museus, quais sejam, uma positivista ou realista, e outra, construtivista. $\mathrm{Na}$ abordagem positivista, compreende-se epistemologicamente o conhecimento como sendo exterior ao aprendiz, ou seja, o corpo do conhecimento é absoluto nele mesmo e, assim, é definido na medida em que pode ser observado, mensurado e objetivado. Na abordagem construtivista, por sua vez, compreende o conhecimento como algo construído a partir da interação do aprendiz com o ambiente social e, nesse caso, a subjetividade é parte dessa construção. Para Greenhill, as abordagens apresentadas acima têm influência tanto sobre o trabalho dos profissionais de museus, quanto sobre a forma do público em utilizar esses espaços.

Partindo da ideia de que os museus são espaços de educação, investigações são desenvolvidas, na busca de entender esse papel e os processos decorrentes da função educacional desses locais, com base em perspectivas teóricas advindas de diferentes áreas de conhecimento. Para Cazelli et al. (2003), a pesquisa em educação e, especialmente, em ensino de ciências, tem proposto modelos teóricos para se entender a complexidade do processo de aprendizagem, principalmente a partir de teorias cognitivistas e sócio-interacionistas, contribuindo para a compreensão desses mecanismos nos museus de ciências. Esta pesquisa, ao assumir os museus como espaços educacionais, se insere no universo das investigações que buscam entender a complexidade dos processos de aprendizagem nos museus. Assim sendo, utilizaremos o tópico a seguir para aprofundar as questões e perspectivas da aprendizagem em museus, especialmente nos museus de ciências, de forma ampla, de acordo com as visões de diversos 
autores. Posteriormente, no capítulo 03, iremos abordar as especificidades da aprendizagem em museus frente aos objetos pedagógicos existentes nesses locais.

\subsection{OS MUSEUS COMO ESPAÇOS DE APRENDIZAGEM}

No que se refere ao papel educativo dos museus, falar de aprendizagem é de suma importância, principalmente para nosso estudo. Assumimos o papel pedagógico dos objetos nos museus e para tal nos apoiamos nas teorias de aprendizagem em museus para argumentar.

Bizerra (2009) faz um levantamento bibliográfico frutífero, que nos faz compreender como a aprendizagem é entendida pelos pesquisadores em educação em museus e quais elementos abordados em seus trabalhos estão relacionados à aprendizagem nesses ambientes. Tomamos assim a revisão feita por essa autora, para compreensão de como a aprendizagem é abordada na literatura da área

Um dos aspectos ressaltados por Bizerra (2009), nos artigos por ela analisados é que poucos apresentam uma definição de aprendizagem. Além disso, na sua percepção, a aprendizagem em museus é vista pelos autores dos artigos muito mais como um processo do que como um produto.

A ideia de aprendizagem como algo contínuo é recorrente, como nas definições de Falcão et al. (2003), em que esta é vista como "um processo de longo prazo que envolve progressos e regressões, muito mais do que simples substituições de ideias" e na de Falk (2001), que vê a aprendizagem como um diálogo entre o indivíduo e o meio, ao longo do tempo. 
Enquanto a percepção de aprendizagem como processo é bastante aceita entre os pesquisadores estudados por Bizerra (2009), o mesmo não acontece quando se analisa como esse processo ocorre nesses espaços. Segundo Bizerra (2009), para alguns autores, a aprendizagem é um processo prioritariamente mental, enquanto para outros ele é social. Para Jeffery-Clay ${ }^{2}$ (1998 apud BIZERRA, 2009), a aprendizagem se dá quando indivíduos mudam estruturas conceituais existentes, criando relações e integrando novos conceitos. Essa posição é semelhante à de Gilbert e Priest (1997), para quem a aprendizagem é o desenvolvimento e o uso de modelos mentais pelos indivíduos, e à de Puchner, Rapoport e Gaskins (2001) em que a aprendizagem envolve mudanças em representações mentais que podem ou não se manifestar no comportamento.

Já para Allen (2002), conforme aponta Bizerra (2009), a aprendizagem é o ato de interpretar para fazer sentido pessoal, mas como atividade articulada de um grupo. Essa visão é condizente com a perspectiva sociocultural adotada por essa autora em suas pesquisas.

Leinhardt, Knutson e Crowley (2002), também adeptos da abordagem sociocultural, ancoram sua definição no discurso do visitante e, portanto, definem a aprendizagem como elaboração conversacional, em que a linguagem é enriquecida pelos detalhes específicos dos objetos e temas dos museus e reflete as conexões pessoais e afetivas realizadas "de uma maneira que vai além das simples declarações gosto ou não gosto" ou da identificação desses objetos ou temas. Percebe-se, assim, que a concepção de aprendizagem desenvolvida pelos autores

\footnotetext{
2 JEFFERY-CLAY, K. Constructivism in Museums: Haow Museums Criate Meaningful learning Environments.
} Journal os Museum Education, Washington, v. 23, n. 1, p. 3-7, 1998. 
depende da teoria educacional utilizada na pesquisa e, dessa forma, pode-se esperar que não exista uma definição consensual do termo, haja vista a variedade de teorias educacionais utilizadas nos museus de ciências (BIZERRA, 2009).

Hein (1998) aponta a necessidade de se compreender as teorias educacionais utilizadas para a pesquisa em museus e acredita que elas requerem a compreensão de dois componentes importantes, quais sejam, uma teoria do conhecimento e uma teoria da aprendizagem. Para ele, os museus podem se posicionar com base em duas premissas quanto à teoria do conhecimento: 1) "o conhecimento existe independentemente do aprendiz", e 2) "o conhecimento existe somente em ideias construídas na mente".

Quanto à teoria da aprendizagem, Hein (1998) enfatiza que a aprendizagem consiste num acúmulo de informações, fatos e experiências e também afirma que a aprendizagem consiste da seleção e organização de sensações do entorno, com a construção de esquemas mentais. Para ele, essas duas dimensões de teorias educacionais podem ser combinadas e produzir diferentes posturas em relação à educação.

Nos estudos de Cazelli et al. (2003), os autores apontam que a investigação educacional em museus de ciências surge com mais ênfase na década de 1970, "com o objetivo geral de informar acerca da natureza dos processos de aprendizagem vividos pelos visitantes, ou seja, a qualidade do que se aprende e a forma como se aprende". Essa ênfase, segundo esses autores, se dá por fatores como o crescimento do número de museus interativos, a ideia do aprender fazendo e a orientação das investigações provocada pelo enquadramento da educação não formal em abordagens cognitivistas e sociológicas. 
Para Valente et al. (2005), o desenvolvimento dos museus de ciências e tecnologia de caráter interativo no Brasil segue do movimento internacional de criação dos science centers. Estes buscam, em seus propósitos, ultrapassar o aspecto marcante de preservação de artefatos da cultura científica e tecnológica até então presente nos museus de História Natural. A dinâmica principal observada nesses centros de ciências foi o trabalho de criar objetos correlatos aos artefatos tecnológicos, culturais e sociais, isto é, o foco da exposição não estava unicamente na musealização de um objeto testemunho, mas na criação de um objeto próprio para a apresentação de um conceito ou produto tecnológico.

Essa prática museológica tornou-se uma possibilidade de acesso às redes de produção de conhecimentos e de fruição cultural, a partir de novos objetos, abrindo, assim, a possibilidade de novas formas de práticas educativas (NASCIMENTO, 2005).

No que se refere, especificamente, ainda ao tema da aprendizagem em museus, Hooper-Greenhill (1994a) indica que os diferentes grupos de visitantes, que frequentam esses espaços, possuem expectativas diferenciadas em relação à aprendizagem. Alguns preferem uma experiência de aprendizagem informal, que pode ser descrita como "livre-aprendizagem", enquanto outros estão mais interessados em uma experiência educacional mais direcionada, proporcionada por mediadores (curadores, professores, monitores, voluntários, artistas etc.).

Hooper-Greenhill ressalta também que o processo de aprendizagem nesses espaços é frequentemente centrado nas exposições e que o "diálogo" entre elas e o público pode assumir diferentes estilos e formas de interpretação. Vale ressaltar que, na sua visão, a partir da década de 1980, a concepção educativa das exposições em 
museus de ciências foi muito influenciada pelas teorias educacionais em vigor, em especial, pelas teorias construtivistas. Estas enfatizam o papel ativo do indivíduo na construção de seu próprio aprendizado e afirmam que a aprendizagem é um processo dinâmico que requer uma interação constante entre o indivíduo e o ambiente.

A partir da década de 1990, os estudos sobre aprendizagem em museus se intensificaram. As investigações sobre a natureza do processo de aprendizagem (FALK; DIERKING, 1995; 1992), sobre a aprendizagem em grupos familiares (BORUN et al., 1995), sobre padrões de interação entre exposições-professoresestudantes (FALCÃO,1999; CAZELLI et al., 1997), sobre a aprendizagem por meio de modelos mentais e modelagem (GILBERT; PRIEST, 1997; GILBERT, 1995; FALCÃO et al., 1998) e sobre aprendizagem com enfoque nas interações sociais (MARANDINO et al., 1998; GASPAR, 1993) demonstraram o avanço qualitativo das pesquisas relacionadas ao tema da aprendizagem em museus (MARANDINO, 2001).

George Hein (1998) é um autor que enfatiza, em seus trabalhos, a aprendizagem em museus e, para ele, os museus devem alterar as suas práticas na direção de promover a emergência do "museu construtivista". A seu ver, os museus podem ativamente apoiar os visitantes, e para tal, é necessário provocar a conectividade entre o seu conhecimento anterior e a informação que as exposições disponibilizam. Neste sentido, Hein $(1995,1998)$ sublinha a necessidade de serem facultadas aos visitantes condições de conforto físico e intelectual.

Normam (1993) indica que as aprendizagens formais e não formais podem facilitar-se mutuamente. O visitante, com saber na área da história da arte, visita 
com mais facilidade uma exposição de arte porque conhece as particularidades dessa linguagem. Compara-os com a acuidade necessária para tirar partido da exposição. O conhecimento que os alunos obtêm a partir do currículo escolar, por exemplo, na área da zoologia, facilita certamente o entendimento do sujeito de uma exposição temática num museu de ciência natural.

Mas a educação formal e não formal também podem se inibir porque, por vezes, os conteúdos transmitidos podem ser contraditórios num e noutro espaço de aprendizagem sobre o mesmo assunto. Os programas informais e formais devem ter atenção para o fato de que a aprendizagem é um processo complexo, não se esgota apenas num dos seus aspectos, por mais importante que ele seja. O programa todo deve ser planejado, tendo em conta a inclusão dos aspectos implicados, tanto a partir das reflexões de outros autores, como na prática da própria experiência (NORMAN, 1993).

A ideia de experimentação parece estar na origem de vários museus interativos de ciências. Como lembra Barry ${ }^{3}$ (1998 apud COLINVAUX, 2005), este é um legado de Frank Oppenheimer. Este, questionando a "glorificação das conquistas de cientistas do passado a expensas de permitir que visitantes se engajem em um processo de descoberta", afirmava que um museu de ciências, ao contrário, deveria oferecer ao público a "possibilidade de interagir com objetos assim como um cientista experimental o faz no mundo natural do laboratório". Nesta perspectiva, ainda segundo Colinvaux (2005), o museu - aliás, assim como o laboratório escolar de ciências - busca reproduzir, em certa medida, o universo das

3 BARRY, A. On interactivity: consumers, citizens and culture. In: MACDONALD, S. (ed.). The politics of display: museums, science, culture. Londres: Routledge, 1998. p. 98-117. 
práticas e procedimentos científicos. Dessa forma, analogamente a cientistas, visitantes seriam convidados a se engajarem em um diálogo com fenômenos da natureza, interrogando-a para descobrir suas leis, seus mecanismos, suas causas (COLINVAUX, 2005).

A metáfora da ciência como interrogação da natureza (GINGRAS; GODIN ${ }^{4}$, 1997 apud COLINVAUX, 2005) evidencia o papel ativo do cientista que, sujeito da ação de interrogar, não se contentará em observar a natureza, mas buscará nela intervir, provocando-a a se manifestar através da experimentação.

A experimentação, então, diferentemente da observação da realidade tal qual ela se apresenta, implica provocar fenômenos novos, de modo artificial, por meio de instrumentos, possibilitando o teste de hipóteses e contribuindo diretamente para o avanço do conhecimento científico (COLINVAUX, 2005).

Dessa forma, ainda para a autora, a ação do sujeito sobre o objeto corresponde à reação do objeto, configurando propriamente uma interação entre sujeito e objeto. Assim, desde Piaget - para quem, se poderia dizer, "na origem está a ação" -, mas também em outros campos das ciências humanas e sociais, assumimos que o sujeito humano está ativamente envolvido em se constituir como sujeito, e mais, como sujeito pensante, portanto intérprete do mundo, construtor de conhecimentos e artífice de suas aprendizagens (COLINVAUX, 2005).

4 GINGRAS, Y.; GODIN, B. Expérimentation, instrumentation et argumentation. Didaskalia: recherches sur la communication et l'apprentissage des sciences et des techniques, v. 11, p. 149-60, 1997. 
Ana Maria Senac Figueroa

OS OBJETOS NOS MUSEUS DE CIÊNCIAS:

o papel dos modelos pedagógicos na aprendizagem

Nesta pesquisa, assumimos que a aprendizagem é um processo. Sua complexidade envolve tanto a dimensão mental como a social. Os sujeitos, em contato com os elementos presentes nos museus, colocam em relação seus conhecimentos anteriores com aqueles sugeridos por meio dos objetos e textos, possibilitando, potencialmente, a reformulação de suas ideias. Ao mesmo tempo, no espaço do museu, essas situações não ocorrem, em geral, de forma isolada. As visitas são feitas, em sua grande maioria, em pequenos grupos e os sentidos e significados expressos nos objetos e textos podem ser negociados, revelando a dimensão social do processo. Buscamos assim, na investigação aqui proposta, analisar esses dois momentos do processo de aprendizagem, a partir da seleção de um objeto da exposição de um museu de história natural - o esqueleto da preguiça gigante.

No próximo capítulo iremos aprofundar, ainda com base na literatura, os aspectos relacionados à aprendizagem por meio de objetos nos museus. 


\section{OS OBJETOS NOS MUSEUS DE CIÊNCIAS}




\section{OS OBJETOS NOS MUSEUS DE CIÊNCIAS}

Museus, objetos e coleções são as três faces de um triângulo cultural, em que cada uma das faces mostra diferentes características para 0 mundo, mas juntas compõem 0 todo (PEARCE, 1992, p. 1).

A extensão e flexibilidade da categoria 'objeto de museu', o qual englobaria itens de diferentes tipos e naturezas e coloca diversas questões, tais como: "ele pode ser artificial ou natural, morto ou vivo, humano ou animal, orgânico ou inorgânico, único ou representativo". Ele merece referência especial não só as imagens e os modelos, mas, também, "fragmentos do mundo" de naturezas muito diversas: de espécimes botânicos e zoológicos conservados in vivo ou in vitro, a imagens e instrumentos científicos (ALBERTI, 2005).

A entrada de um objeto em um museu é ressaltada por Bellaigue e Menu (1994), como o ingresso em um "lugar de artifício", o que implicaria a "transformação semântica radical" do objeto. Para os autores, esse "fragmento do real colocado no museu", em si mesmo "imóvel e silencioso", passa a contar histórias, documentar e colocar questões.

Para Pearce (1992), os objetos de museu são como "pedaços do mundo físico". Estes, no entanto, não se restringiriam àqueles "pedaços discretos capazes de ser movidos de um lugar para outro", mas compreenderiam todo o mundo físico, inclusive as paisagens. Assim como inúmeros outros estudiosos, a autora enfatiza o ato da seleção que, ao agregar valor cultural a um "pedaço do mundo", transforma-o em objeto. 
Além de ressaltar o ato de seleção, Mensch ${ }^{5}$ (1992 apud LOUREIRO, 2007) privilegia a função documental do objeto: objetos de museus são objetos separados de seu contexto original (primário) e transferidos para uma nova realidade (o museu), a fim de documentar a realidade da qual foram separados. Para ele, um objeto de museu não é só um objeto em um museu, é um objeto coletado (selecionado), classificado, conservado e documentado. Como tal, ele se torna fonte para a pesquisa ou elemento de uma exposição.

Tal como Pearce (1992), Mensch ${ }^{6}$ (1992 apud LOUREIRO, 2007) ressalta que sua definição de cultura material "não se limita aos artefatos tangíveis, móveis, mas inclui todos os artefatos, do mais simples, como um alfinete comum, ao mais complexo, como um veículo espacial interplanetário". Segundo ele, a primeira tentativa de definir o conceito de objeto de museu teria ocorrido na antiga União Soviética, em 1955, sendo retomada por outros autores. Em 1969, Stransky cunharia o termo 'musealium' para distinguir os objetos de museu dos objetos em geral, observando posteriormente - no Encontro do International Committee for Museology (ICOFOM), em 1985 - que, embora "ontologicamente coincidentes", seriam diferentes "sob um ponto de vista semântico" (LOUREIRO, 2007).

Porém, para Morton (1997), o objeto, ainda, é um elemento fundamental, para não dizer a razão de ser do museu. Os objetos são elementos que moldam nossa vida cotidiana, são produtos de seu tempo, socialmente construídos e cada um é um "microcosmo trazendo consigo o rastro do macrocosmo".

\footnotetext{
$5 \mathrm{MENSCH}$, P. V. Towards a methodology of museology. 1992. Tese (Doutorado) - University of Zagreb, Zagreb, 1992.

6 MENSCH, P. V. Towards a methodology of museology. 1992. Tese (Doutorado) - University of Zagreb, Zagreb, 1992
} 
O significado do objeto dentro do museu deriva dos vários ambientes sociais, econômicos, políticos e culturais pelos quais passa, em outras palavras, através de sua "biografia" e da interpretação associada (SILVERSTONE, 1992). Assim, para Marandino (2001), os objetos constituem uma das razões de ser da exposição. Sua exibição dá lugar a que se entenda, que há exposição e independe do lugar em que se encontre. Se não existissem objetos, não haveria exposição. Com essa premissa, a existência de coleções marca a história e o próprio conceito de museus ao longo dos séculos.

Os primeiros museus se constituíram a partir do acúmulo de objetos, oriundos, desde os séculos $\mathrm{XV}$ e XVI, dos novos continentes descobertos. Ao longo dos períodos que se seguiram, diferentes formas de organização dessas coleções nos espaços foram sendo constituídas, entre outros fatores, a partir das visões de ciência e de museologia que se apresentavam (MARANDINO, 2001).

Nessa pesquisa, buscamos saber mais sobre os objetos existentes nos museus concordando, dessa forma, com posições que afirmam ser este elemento, central em qualquer definição de museu. Por isso, como aponta Valente (2005), a exposição em um museu é algo mais, porque mostra objetos determinados, objetos que são valorizados como importantes de serem vistos, admirados, contemplados. Além disso, para a autora, os objetos são expostos porque possuem uma conceitualização, ou seja, encerra conceitos e contextos importantes para uma determinada temática, uma determinada comunidade, um determinado público, faz parte de um patrimônio intangível, ou seja, o patrimônio que está ligado aos aspectos relativos à conservação dos processos e fenômenos, incluindo o cultural e o natural. E ainda compreende todos os atos de criação, inclusive o da Ciência. 
Neste sentido, para Van-Präet (2002), a museologia contemporânea das ciências e das técnicas não pode fazer abstração da reflexão e das investigações sobre este patrimônio. Para ele, o sucesso de uma exposição acontece, sobretudo, quando ocorre a operacionalização de uma trama de concepções, em que o desenvolvimento dos conteúdos e da forma combina vários procedimentos. Assim, como a entrada do patrimônio intangível reestruturou profundamente a instituição museu, transformando os museus de ciências e levando amplamente à criação dos centros de ciências que privilegiam a apresentação de fenômenos naturais, é fundamental, hoje, ultrapassar as formas atuais de mediação para responder aos desafios da comunicação.

No que se refere às teorias de comunicação aplicadas ao contexto de museu, Hooper-Greenhill (1994a) afirma que o sentido do objeto na exposição é condicionado pela relação que ele estabelece com os outros objetos e com os recursos utilizados, através de etiquetas e textos, para auxiliar na interpretação pelo visitante. Assim, para Moya (1998), as coleções são as principais ferramentas dos museus, nas quais se baseiam as exposições e os programas educativos e incluem os objetos de importância "estética, histórica, educativa ou científica".

No caso específico dos museus de ciências, a autora acima citada, aponta que "as coleções têm a função didática de comunicar ao visitante o espírito e a mentalidade dos cientistas, a fim de promover sua inclinação natural pela ciência". Além disso, as coleções devem também "responder a uma guia conceitual que coincida com os objetivos do museu e necessidades da comunidade". Admite, ainda, que nos museus modernos de ciências, as coleções não são formadas somente por espécimes e objetos históricos, mas também por aparatos interativos, materiais 
Ana Maria Senac Figueroa

OS OBJETOS NOS MUSEUS DE CIÊNCIAS:

o papel dos modelos pedagógicos na aprendizagem

audiovisuais, jogos de computador, fotografias, ilustrações, incluindo também os documentos (MOYA, 1998).

Para Leinhardt e Crowley (2002), há quatro categorias de objetos que os fazem únicos, para a construção de ideias e suas elaborações. São elas: resolução e densidade da informação, escala, autenticidade e valor.

A primeira característica apontada pelos autores trata da resolução e densidade da informação, ou seja, dos objetos reais em oposição às representações bidimensionais desses objetos. Para eles, fotografias e desenhos podem incorporar muitas características visuais de um objeto, mas são abstrações para as quais o fotógrafo ou o artista decide quais as características para preservar e quais devem ignorar. Uma fotografia de uma pintura completa pode permitir que os espectadores apreciem a composição, mas a sutil gradação de cores e pinceladas serão perdidas.

Da mesma forma, outros recursos disponíveis apenas a partir de objetos são aqueles que não podem ser fotografados, ou seja, o cheiro e o som de um elefante no zoológico, a textura de uma folha num jardim botânico, ou o peso de uma panela de ferro fundido, do período colonial, em um centro de história.

Embora muitas destas características possam ser descritas completamente e, talvez, serem representadas em aproximações com a realidade, a coleção holística de características para um objeto não pode ser eficientemente representada na ausência do objeto (LEINHARDT; CROWLEY, 2002).

Já em contraste com pinturas desenhos e fotografias, em que a escala é ausente ou requer uma transformação matemática (por exemplo, uma pessoa em pé, ao lado de um osso de dinossauro), os objetos nos museus estão colocados em 
Ana Maria Senac Figueroa

OS OBJETOS NOS MUSEUS DE CIÊNCIAS:

o papel dos modelos pedagógicos na aprendizagem

escala real. Em muitos casos, a pequenez ou a grandeza do objeto é a característica mais notada.

Sobre a autenticidade, Leinhardt e Crowley (2002) afirmam que ela existe somente na interação entre objetos específicos de nossa história e cultura. Assim, a cama de Napoleão é autêntica porque um especialista disse que foi nela que ele dormiu e nós acreditamos nisso. A resposta para essa autenticidade é que o visitante fica próximo a ela e, de algum modo, compartilha o objeto com Napoleão. Assim, a partir da autenticidade de um objeto, também lhe é atribuído valor, mas nem sempre o valor de um objeto é ser apenas autêntico. Por valor, os autores se referem ao objeto que é único e, em muitos casos, o valor monetário do objeto também conta. Consideram, então, que essas características somadas às conversas dos visitantes nos museus fazem dos objetos os principais responsáveis pela aprendizagem nesses espaços (LEINHARDT; CROWLEY, 2002).

Lourenço (2000) discute, ainda, a natureza dos objetos nos Museus de Ciência e Técnica. A definição de objeto utilizada por Lourenço se fundamenta em Mensch (1992), o qual afirma que "um objeto é o elemento de uma cultura material a que podemos reconhecer uma identidade própria". Para a autora, entende-se que a cultura material é constituída "pelo ambiente físico que o homem vai alterando através de comportamentos culturalmente condicionados". Portanto, os objetos de museus são, por definição e obrigação, fonte de informação. Não se trata de meros objetos, mas sim de objetos extraídos de uma determinada realidade com o objetivo de documentá-la (MARANDINO, 2001).

Neste sentido, para Lourenço (2000), não há problemas com a identificação entre os objetos que comumente aparecem nos museus "tradicionais" de ciência e 
Ana Maria Senac Figueroa

OS OBJETOS NOS MUSEUS DE CIÊNCIAS:

o papel dos modelos pedagógicos na aprendizagem

tecnologia como objetos de museus, o que não ocorre com aqueles que geralmente estão presentes nos centros de ciência e, para explicar, a autora propõe, um sistema de classificação de objetos em Museus de Ciência e Técnica. Para tal, chama atenção quanto à confusão existente e, logo, da necessidade de se distinguirem os conceitos de "propósito de construção" e de "contexto de utilização" dos objetos, já que "um sistema de classificação baseado no contexto de utilização seria mais complexo em se estabelecer, porque os objetos são "cegos" relativamente, ao uso que se lhes é dado".

Assim, o sistema de classificação elaborado por Lourenço (2000) é baseado na informação que pode ser retirada do objeto e é de âmbito restrito, pois pode ser aplicado apenas a "objetos que foram construídos com o propósito de serem utilizados: i) num contexto de investigação científica; ii) num contexto de ensino formal da ciência ou ainda iii) num contexto de divulgação da ciência", o que deixa de fora os objetos tecnológicos e não científicos. Desta forma, a autora propõe três grandes tipos de objetos em museus de Ciência e Técnica:

- Objetos científicos: que foram construídos com o propósito de investigação científica.

- Objetos pedagógicos: que foram construídos com o propósito de ensinar ciência.

- Objetos de divulgação da ciência: que foram construídos com o propósito de apresentar os princípios da ciência a um público mais vasto.

É importante enfatizar que, para Lourenço, do ponto de vista museológico, os objetos pedagógicos se aproximam tanto dos de divulgação quanto dos 
Ana Maria Senac Figueroa

OS OBJETOS NOS MUSEUS DE CIÊNCIAS:

o papel dos modelos pedagógicos na aprendizagem

científicos. Ainda, no sistema de classificação de Lourenço, os atributos "valor histórico" e "participatividade" ou "contemplação" são transversais, podendo ser encontrados em qualquer objeto. Além disso, para a autora, os objetos científicos pertencem, na verdade, ao grupo das chamadas coisas "reais", enquanto os pedagógicos e de divulgação da ciência ao grupo dos "modelos".

Para a autora em questão, entende-se como coisa real "aquelas que nós apresentamos tal e qual são, sem recorrer a representações" e modelos "representações de qualquer objeto, fenômeno ou conceito e calculados para refletir o original, de acordo com seus objetivos".

No nosso trabalho, tratamos o objeto escolhido, o modelo do esqueleto da preguiça gigante, como na definição de Lourenço (2000), ou seja, como um objeto pedagógico, construído a partir do original, ou seja, um modelo com a clara intenção de ensino e de aprendizagem.

Utilizaremos, portanto, para esse estudo, o termo objeto pedagógico e modelo pedagógico como sendo termos sinônimos, por concordarmos com a definição dada por Lourenço (2000).

Apresentaremos, a seguir, alguns estudos das relações dos objetos com a educação e com a aprendizagem, com a finalidade de articulação desses estudos com os dados obtidos em nossa pesquisa.

Uma revisão da literatura acerca do tema "modelo pedagógico", segundo o artigo por nós publicado em 2009 (FIGUEROA; MARANDINO, 2009), em um importante encontro brasileiro da área de ensino de ciências, também poderá nos auxiliar na compreensão de como os modelos pedagógicos nos museus de ciências 
Ana Maria Senac Figueroa

OS OBJETOS NOS MUSEUS DE CIÊNCIAS:

o papel dos modelos pedagógicos na aprendizagem

estão colocados nas pesquisas, nacionais e internacionais, para melhor compreendermos como eles se caracterizam em seu papel pedagógico.

\subsection{OS MODELOS PEDAGÓGICOS E SUAS RELAÇÕES COM A EDUCAÇÃO}

O papel educacional dos museus deve ser analisado na perspectiva do visitante, das suas concepções, da sua agenda, de seus conhecimentos e interesses. Para isso, um dos instrumentos utilizados é a compreensão do processo de interpretação dos visitantes nos museus e, nesse sentido, Hooper-Greenhill (1994a) explicita os procedimentos para o desenvolvimento de análise do processo, que devem considerar as especificidades do local, especialmente quanto aos objetos que possuem.

Para Falk (2002), a relação entre objetos, visitantes e museus tem sido considerada um "dos tópicos mais importantes para o entendimento de como os museus funcionam como espaços educativos, culturais e de lazer".

Para discutir essas relações, Scott Paris, em 2002, editou uma obra em que 30 diferentes pesquisadores apresentam seus estudos sobre a aprendizagem baseada em objetos. Para o autor, esses estudos se justificam na presença de uma relativamente nova área de pesquisa para psicólogos e educadores que, embora recente, tem precedentes antigos: curadores e educadores de museus estudam os objetos e sua exibição desde o século XIX; antropólogos, considerando os objetos como evidências da cultura material, construíram teorias sobre eles e seus significados; psicólogos estudam os comportamentos dos visitantes de museus desde a década de 1920; diversos educadores ressaltam a importância do manuseio 
Ana Maria Senac Figueroa

OS OBJETOS NOS MUSEUS DE CIÊNCIAS:

o papel dos modelos pedagógicos na aprendizagem

de objetos para a aprendizagem e filósofos têm enfatizado o valor da experiência educativa baseada em objetos genuínos. Assim, para o autor citado acima, o histórico da educação baseada em objetos tem "uma história longa e multidisciplinar".

Assim, tendo em vista os diversos sentidos e variados referentes - de objetos em museus às representações de cientistas e estudantes - associados ao termo modelo, no campo da educação em ciências, Gilbert e Boulter ${ }^{7}$ (1998 apud KRAPAS et al., 1997) argumentam que é necessário discutir o tema dos modelos nos museus.

Sobre os modelos, buscamos alguns referenciais teóricos do ensino de ciências que corroboram com autores que tratam da aprendizagem por meio de objetos em museus e, portanto, vão ao encontro das perspectivas dessa pesquisa.

Para Duit e Glynn (1996), um modelo pode substituir ou ocupar o lugar de alguma coisa que ele representa. Para eles, o uso de modelos pedagógicos visa promover "caminhos intelectuais" específicos de compreensão dos modelos consensuais pelos estudantes, de tal modo que "o modelo pedagógico se torna a fonte, ou seja, a analogia, a partir da qual se desenvolve um modelo mental aceitável do modelo consensual". Enfatizam, ainda, o papel central das analogias na construção de modelos mentais. Diante do domínio alvo (conceito), relações analógicas entre ele e um domínio que serve de fonte (analogia) são estabelecidas, colocando em evidência atributos e certas partes das estruturas comuns a ambos,

GILBERT, J.; BOULTER, C. Learning science through models and modelling. In: FRAZER, B.; TOBIN, K. (Eds). The International Handbook of Science Education. Dordrecht: Kluwer, 1998. 
Ana Maria Senac Figueroa

OS OBJETOS NOS MUSEUS DE CIÊNCIAS:

o papel dos modelos pedagógicos na aprendizagem

que farão parte do modelo. Portanto, para eles, as relações analógicas são o "coração" dos modelos.

Pensando no campo pedagógico do ensino de ciências, os autores acima citados consideram as analogias como ferramentas de aprendizagem utilizáveis, com as devidas precauções, pelos professores, para incitar processos de raciocínio em seus alunos. Quando algum produto resultante de um processo de modelagem passa a ser compartilhado por certa comunidade, recebe o nome de modelo conceitual e pode ser, em determinadas situações, transformado em um objeto concreto. Em ambos os casos, o que importa é a representação mental que se tem do modelo conceitual (ou do objeto que o representa) e que pode ser usada por várias pessoas. Modelos mentais e modelos conceituais são, portanto, representações de processos ou objetos do mundo real, construídos basicamente através do estabelecimento de relações analógicas (DUIT; GLYNN, 1996).

Assim, Nagem (2001) acentua a importância dos modelos pedagógicos, que deriva de sua aplicação, para o estabelecimento de relações entre o alvo (conceito) e o veículo (modelo/analogia), sendo possível, assim, explorar o análogo presente nessas situações de ensino.

Diante do que foi explicitado, Gilbert e Boulter ${ }^{8}$ (1998 apud KRAPAS et al., 1997) propõem, então, que modelos sejam definidos como "a representação de uma idéia, um objeto, um evento ou um sistema" e distinguem vários modelos: "o modelo mental (uma representação pessoal, privada de um alvo), o modelo expresso (aquela versão de um modelo mental que é expressa por um indivíduo através da

8 GILBERT, J. K.; BOULTER, C. J. Learning science through models and modelling. In: FRAZER, B.; TOBIN, K. (Eds.). The international handbook of science education. Dordrecht: Kluwer, 1998. p. 53-66. 
Ana Maria Senac Figueroa

OS OBJETOS NOS MUSEUS DE CIÊNCIAS:

o papel dos modelos pedagógicos na aprendizagem

ação, fala ou escrita), o modelo consensual (um modelo expresso que foi submetido a teste por um grupo social, por exemplo, a comunidade científica, e que é visto, pelo menos por alguns, como tendo mérito), e o modelo pedagógico (um modelo especialmente construído para auxiliar na compreensão de um modelo consensual)".

Krapas et al. (1997) partem da definição de modelo como a representação de uma idéia, objeto, evento, processo ou sistema, e de modelagem como o processo de construção de modelos, e elaboram, a partir da interação com as referências, um conjunto de cinco categorias, que definem como:

- Modelo mental: modelo pessoal, construído pelo indivíduo e que pode se expressar por meio da ação, da fala, da escrita, do desenho.

- Modelo consensual: modelo formalizado rigorosamente, compartilhado por grupos sociais, com o propósito de compreender/explicar ideias, objetos, eventos, processos ou sistemas.

- Modelo pedagógico: modelo construído com o propósito de promover a educação. No sentido amplo, um modelo pedagógico inclui os processos de mediação didática, isto é, os processos de transformação de conhecimento científico em conhecimento escolar.

- Meta-modelo: modelo formalizado rigorosamente, compartilhado por grupos sociais, e construído com o propósito de compreender/explicar o processo de construção e funcionamento de modelos consensuais ou de modelos mentais. 
- Modelagem com objetivo educacional: enfatiza a promoção da competência em construir modelos como propósito central do ensino de ciências.

Em nossa pesquisa, buscamos, portanto, elucidar também como os teóricos em aprendizagem em museus tratam a questão dos modelos. Encontramos na literatura pertinente, tanto o termo "modelo" para denominar o objeto que foi construído com a função de ensino e de aprendizagem, como o termo "substituto". Para os objetos originais, encontramos o termo "autêntico" para tal denominação.

Michel Van-Präet, um importante autor que trata da questão da autenticidade dos objetos, discute, em vários artigos e capítulos de livros, a mudança de foco dos objetos para os processos, que caracterizou os museus de ciências no século XIX. Ele foi responsável pela conformação do conceito moderno de museu, pautado na divisão do espaço em reservas, exclusividade dos especialistas, e galeria de exposições, área destinada ao público em geral. Essa transferência de interesse representa para Van-Präet (2002) o rompimento com os limites da inventariação e descrição, ampliando-se em direção à abordagem dos processos naturais e sociais como forma de aprofundar o domínio sobre a natureza e seu conhecimento.

No entanto, para o autor, essa mudança se baseia em um dilema, calcado tanto na necessidade de se proteger os objetos originais do perigo representado pelas exposições, cujas cenografias iriam desarrumar o arranjo e a conservação das coleções, como na de se ampliar o aspecto educacional dos museus, por meio da elaboração de exposições que buscam divulgar os novos conceitos e disciplinas interessadas no estudo dos processos (VAN- PRÄET, 2002). 
Nesse sentido, para Van-Praët (2003), substitutos e autênticos são conceitos pertinentes na análise das coleções de história natural, ou quando, aprofundando-se os exemplos, percebe-se que todo o patrimônio é uma construção humana e, portanto, são do domínio do intangível. Analisar o uso de modelos e substitutos, em história natural, remete à própria natureza das coleções nas disciplinas que a compõem e ao estatuto dos objetos apresentados nas exposições. Ainda ressalta que, se o modelo é frequente em paleontologia e às vezes utilizado em zoologia, a questão do uso do substituto coloca-se em outro lugar que não em uma disputa entre o autêntico e o fictício. Segundo Deloche ${ }^{9}$ (apud VAN-PRAËT, 2003), "a variedade de substitutos é grande e não escapa a todas as formas de ambiguidade" em todas as exposições e não somente naquelas sobre temas científicos.

No caso da história natural, o que provavelmente convém valorizar melhor para os visitantes, é que nada é "realmente natural" entre os espécimes expostos. Tudo, aí, é substituto, ou mais precisamente produto de conhecimentos, o que não impede a emoção que o visitante sente quando se confronta com uma montagem paleontológica ou com um espécime naturalizado. Bem ao contrário, isso permite enriquecer e prolongar a emoção, ao se exibir sua gênese, que associa uma multidão de intervenientes: cientistas, técnicos, conservadores, museólogos, cenógrafos etc. (VAN-PRAËT, 2003).

Limitando-nos às questões da paleontologia, devido à escolha do modelo pedagógico em nosso estudo, para Van-Praët (2003) ocorre que buscar estabelecer um limite entre um "autêntico produto da Natureza" e um "substituto" tem pouca pertinência e até mesmo mascara questões essenciais, seja do ponto de vista da

\footnotetext{
9 DELOCHE, Bernard. Le musée virtuel. Paris: PUF, 2001. 265p.
} 
Ana Maria Senac Figueroa

OS OBJETOS NOS MUSEUS DE CIÊNCIAS:

o papel dos modelos pedagógicos na aprendizagem

exposição, seja da perspectiva da epistemologia da disciplina. Para ele, o objeto paleontológico é sempre uma produção cultural. Dos viveiros de peixes do século XVII aos peixes conservados em álcool etílico, a partir do final do século XVIII, dos modelos de espécies ao desenvolvimento dos grandes aquários, no final do século $\mathrm{XX}$, os questionamentos científicos, as possibilidades técnicas e as finalidades científicas e culturais são determinantes do eventual objetivo de conservação da Natureza e sua apresentação para os visitantes de uma exposição.

No mesmo sentido, em paleontologia, a concepção amplamente difundida na sociedade de uma era secundária povoada por dinossauros monstruosos, resulta da criação de substitutos, sob o comando dos cientistas, bem antes do desenvolvimento dos filmes de animação. Sem remontar às figurações do mito do dragão, as reconstituições dos dinossauros tiveram impulso desde a metade do século XIX, com as esculturas em tamanho natural instaladas em Londres, em 1851, ao redor do Cristal Palace, entre a multidão das descobertas do início daquele século. A partir de 1908, o esqueleto do diplodocus, da galeria de paleontologia do Museu de Paris, contribuiu para forjar a imagem dos grandes vertebrados do secundário entre várias gerações de visitantes na França. Mas é exatamente a mesma imagem que se forjou paralelamente entre os visitantes dos museus de Londres, Berlim, Bolonha, La Plata, México e Viena, onde estiveram expostas, há um século, réplicas do mesmo modelo (VAN-PRAËT, 2003).

Segundo o autor, a informação que constava da etiqueta dessas sete réplicas era a seguinte: "Modelo do esqueleto de Diplodocus carnegiel", e a natureza do substituto podia ser claramente estabelecida com relação a um original. Isso parece estar de acordo com alguns artigos que indicam a existência desse original 
Ana Maria Senac Figueroa

OS OBJETOS NOS MUSEUS DE CIÊNCIAS:

o papel dos modelos pedagógicos na aprendizagem

no Carnegie Museum de Pittsburg. Uma etiqueta mencionava, neste caso, "Esqueleto de Diplodocus carnegiel", omitindo-se, contudo, de indicar duas informações essenciais. Tratava-se de uma reconstituição, porque os paleontólogos raramente encontram esqueletos completos, e estes nunca estão em posição anatômica e, além do mais, essa reconstituição era um compósito de materiais diversos. Na verdade, depois da descoberta dos primeiros elementos das vértebras e de uma parte de um membro, em 1877, no Colorado e, alguns anos mais tarde, de um crânio, no mesmo local, foi a partir dessas peças, mas também daquelas que vinham de dois outros indivíduos descobertos em Wyoming, em 1899 e 1900, que se construiu a montagem exposta. Por um lado, ela testemunha o progresso dos conhecimentos na paleontologia, no início do século XX e, por outro, contribui para criar o imaginário social sobre os grandes répteis do secundário. Desse ponto de vista, mencionar os procedimentos dos paleontólogos (e seu trabalho de reconstituição) provavelmente é mais informativo para os visitantes do que a indicação "modelo" que consta nas réplicas (VAN-PRAËT, 2003).

Ainda para o autor citado acima, o modelo é onipresente desde a origem da paleontologia que, para simplificar, tem início com Cuvier, no começo do século XIX. Desde essa época, os paleontólogos utilizam maciçamente os modelos em seu trabalho cientifico e nos intercâmbios com seus colegas. Eles colocam os modelos nos espaços de exposição, geralmente sem indicar para os visitantes que um objeto é composto a partir de elementos, original ou não, montado de maneira anatômica em função dos conhecimentos do momento.

A primeira idéia, para Van-Präet, é que o modelo irá permitir uma exposição sem risco. Isso é tanto mais importante no contexto da paleontologia porque a 
Ana Maria Senac Figueroa

OS OBJETOS NOS MUSEUS DE CIÊNCIAS:

o papel dos modelos pedagógicos na aprendizagem

maioria dos fósseis é constituída por peças únicas, mesmo quando eles são compósitos, como o Diplodocus carnegiei, acima mencionado. Para citar outros exemplos, este também é o caso dos sete fósseis do Archaeopteryx que escondem em si, cada um deles, uma parcela de informação complementar sobre esse grupo de pequenos répteis do secundário que têm características de pássaros.

No caso do fóssil de nossa antepassada longínqua Lucy, que viveu há 2,8 milhões de anos, os elementos expostos também são, onde quer que eles possam ser vistos, modelos do precioso fóssil (VAN-PRAËT, 2003).

Se o uso do modelo é tão natural, diz o autor, é porque ele faz parte do ambiente de pesquisa dos paleontólogos; de um lado, vários tipos de fossilização assemelham-se a modelos naturais; por outro, os modelos têm um interesse científico para os paleontólogos. Suas dimensões e volumetrias comportam uma parte de informação suficiente para inúmeros estudos. Sua manipulação permite, assim, que se testem hipóteses de reconstituição anatômica.

Como na escavação arqueológica, o modelo permite, além do mais, conservar os traços dos diferentes estágios de descoberta do fóssil. Na exposição "Ossadas", realizada em 1998, no contexto do projeto de renovação da galeria de paleontologia do Museum, foram cenografados alguns estágios sucessivos de descoberta de um mesmo fóssil, para introduzir elementos relativos ao procedimento do paleontólogo, mais tal disposição museográfica é rara, porque o usual em paleontologia é valorizar as reconstituições anatômicas (VAN-PRAËT, 2003).

Ainda para o autor, o frequente uso científico dos modelos em paleontologia, em particular no processo de reconstituição anatômica, realizada pelos 
Ana Maria Senac Figueroa

OS OBJETOS NOS MUSEUS DE CIÊNCIAS:

o papel dos modelos pedagógicos na aprendizagem

paleontólogos, leva a que se distinga menos nessa disciplina do que nas outras, o estatuto de substituto ou de original, já que o próprio estatuto de original não é idêntico àquele que pode ser definido para a arte. Acentua, que

[...] o uso de modelos e de esculturas desenvolve-se paralelamente em diversas exposições, mas, sobretudo as noções de real e de substituto encontram, como na paleontologia, limites que é preciso mencionar para os visitantes. É claro que tal espécime naturalizado está submetido aos conhecimentos e às finalidades científicos, assim como as modas estéticas da época de sua montagem. (VAN-PRÄET, 2003, p. 60)

As montagens do século XIX, para o autor citado, dominadas pelos objetivos de classificação sistemática das espécies, nunca estão nas posições anatômicas das montagens dos dioramas naturalistas desenvolvidos a partir do final do mesmo século. Se o modelo é frequente em paleontologia e às vezes utilizado em zoologia, a questão do uso do substituto coloca-se em outro lugar que não em uma disputa entre o autêntico e o fictício.

No caso considerado, da história natural, o que provavelmente convém valorizar melhor para os visitantes é que nada é "realmente natural" entre os espécimes expostos. Tudo, aí, é substituto, ou mais precisamente produto de conhecimentos, o que não impede a emoção que o visitante sente quando se confronta com uma montagem paleontológica ou com um espécime naturalizado. Bem ao contrário, isso permite enriquecer e prolongar a emoção, ao se exibir sua gênese, que associa uma multidão de intervenientes: cientistas, técnicos, conservadores, museólogos, cenógrafos etc. (VAN-PRAËT, 2003).

Assim, para o autor, quando se mobiliza a ideia de que o objeto de museu e, a fortiori, a exposição são construções sociais, os propósitos ganham toda força de 
Ana Maria Senac Figueroa

OS OBJETOS NOS MUSEUS DE CIÊNCIAS:

o papel dos modelos pedagógicos na aprendizagem

Tilden $^{10}$ (1957 apud VAN-PRAËT, 2003) sobre a prioridade a se dar, na educação no museu, à interpretação, assim como os de Cameron $^{11}$ (1968 apud VAN-PRAËT, 2003) sobre a importância que deve se atribuir à iniciação à linguagem não-verbal da exposição.

Para os autores, não se trata de ignorar, entre os objetivos de educadores e de museólogos, a difusão dos conteúdos científicos, mas de incluir, entre nossos objetivos, uma educação do olhar e do espírito do maior número de nossos visitantes com relação à cenografia e à museologia, para uma educação global do visitante.

Recentemente, os papéis acadêmicos, preservacional e educacional dos museus de ciência tornaram-se objeto de controvertido debate. A percepção dos museus como meros repositórios de objetos colecionados do mundo natural evoluiu para a concepção de que tais objetos devem ser inseridos em um contexto facilmente compreensível pelo visitante, o qual nem sempre teve acesso a uma educação científica formal.

Há pouco tempo, o maior número de pesquisas realizadas nos centros de ciências se relacionava aos objetos e experimentos expostos, procurando formas de construí-los, expor e apresentar de maneira mais eficiente, em termos de aprendizagem.

\footnotetext{
10 TILDEN, Freeman. L'interprétation de notre patrimoine. (1957). In: DESVALLÉES, André (org.). Vagues. Une anthologie de la nouvelle muséologie. Mâcon: Éditions M.N.E.S, 1992. p. 248-249.

11 CAMERON, Duncan. A view point: the museum as a communication system and application for museum education. Curator, n. 11, p. 33-40, 1968
} 
Ana Maria Senac Figueroa

OS OBJETOS NOS MUSEUS DE CIÊNCIAS:

o papel dos modelos pedagógicos na aprendizagem

Dentro das pesquisas citadas acima, há uma linha que adota um ponto de vista extremamente prático, e que, segundo Gaspar (1993), pode ser sintetizada nas palavras de MacNamara, a seguir,

\begin{abstract}
Apesar da ausência de teorias úteis sobre como os visitantes aprendem em museus, nós podemos melhorar nossas exposições através de metodologias pragmáticas e empíricas, pesquisando cuidadosa e sistematicamente 0 relacionamento entre visitantes e 0 que está exposto em nossos próprios museus (MACNAMARA ${ }^{12}$, 1990 apud GASPAR, 1993, p. 47).
\end{abstract}

Mas, o que fazem ser os museus lugares únicos de aprendizagem? Museus são lugares onde os objetos e mensagens são selecionadas por seu alto valor cultural e, algumas vezes, os objetos são colocados em museus por serem o único exemplar de uma categoria, ou seja, o mais velho, o maior, o mais raro ou o mais complexo.

Paris (2002) ressalta que os objetos nos museus possuem um papel de fundamental importância na aprendizagem, principalmente com relação à construção de significados que os visitantes fazem acerca desses mesmos objetos.

Para lidar com a complexidade e riqueza da aprendizagem e construção de significados por meio de objetos nos museus, Falk e Dierking (2000) desenvolveram um Modelo Contextual de Aprendizagem, que sugere três contextos sobrepostos, os quais contribuem e influenciam as interações e experiências com objetos e a consequente aprendizagem e construção de significados. São eles: o contexto pessoal, o contexto sociocultural e o contexto físico. E, a partir deles, os autores

\footnotetext{
${ }^{12}$ MCNAMARA, P. A. Trying It Out. In: ASSOCIATION OF SCIENCE TECHNOLOGY CENTER - ASTC. What
} Research Says about Learning in Science Museuns. Washington: ASTC, 1990. p. 13-15. 
Ana Maria Senac Figueroa

OS OBJETOS NOS MUSEUS DE CIÊNCIAS:

o papel dos modelos pedagógicos na aprendizagem

definem aprendizagem como sendo o processo/produto das interações entre esses contextos e afirmam, ainda, que ela é mais descritiva do que preditiva.

Segundo Falk e Dierking (2000), o Modelo Contextual de Aprendizagem fornece uma estrutura para organizar informações sobre aprendizagem por meio de objetos e experiências; os detalhes variam de acordo com o contexto específico do aprendiz.

Assim, concluímos que, diante da revisão da literatura acima descrita, um modelo pedagógico, estando ele em espaços formais ou em espaços não formais de educação, promove relações pertinentes com a educação. Portanto, e a partir dessa importante revisão, discutiremos a seguir, as relações desses objetos pedagógicos, que estão inseridos nos museus, com as possíveis aprendizagens, segundo referenciais teóricos da área.

\subsection{OS MODELOS PEDAGÓGICOS E SUAS RELAÇÕES COM A APRENDIZAGEM}

O processo de aprendizagem nos museus de ciências é frequentemente centrado nos objetos e o "diálogo" entre estes e o observador pode ter diferentes formas e penetrar num espectro variado de campos (HOOPER-GREENHILL, 1994a).

Para Carr (1991), os objetos devem refletir uma disciplina, pessoas ou eventos históricos, mas os aspectos que diferem a maioria dos museus são as suas coleções e vitrines de objetos, que são a base para a interface com o público. 
Dessa forma, os modelos pedagógicos dos museus vêm sendo questionados por autores como Hooper-Greenhill (2000), John Falk (1999), George Hein (1995) e Scott Paris (2000), dentre outros.

Para eles, os modelos adotados pela educação em museu repetiram os esquemas que a escola tradicional utilizou. Autores e educadores articulam diferentes descrições e diferentes abordagens do construtivismo, estas geralmente associadas a Lev Vygotsky e a Jean Piaget.

A tese central argumentada pelos atores citados é que cabe ao sujeito elaborar o seu próprio conhecimento: o conhecimento não pode apenas ser transmitido de uma pessoa a outra; ele é construído pelo sujeito. Todo o conhecimento assenta na sua natureza social.

Assim, as pesquisas recentes na área têm se preocupado em compreender como as pessoas "leem" os objetos nos museus e quais as interpretações e significados que elas constroem a partir deles (ROWE, 2002). Algumas olham para o contexto, tentando compreender o papel das instituições museais na aprendizagem sobre, por meio de e com o objeto. Outras buscam entender a natureza das interações, principalmente discursivas, baseadas no objeto (BORUN, 2002; LEINHARDT; CROWLEY, 2002).

No estudo desenvolvido por Rowe (2002), citado anteriormente, o autor procura analisar o papel dos aparatos museais para a construção de significados entre membros de grupos de visitantes. Ressalta que, em parte, o que faz dos museus um local único de aprendizagem é o fato de que modos múltiplos de interagir acerca de e com objetos são incentivados. Para ele, a "natureza da 
Ana Maria Senac Figueroa

OS OBJETOS NOS MUSEUS DE CIÊNCIAS:

o papel dos modelos pedagógicos na aprendizagem

atividade e o significado do objeto nos museus estão prontos para negociar com os visitantes".

Nós adquirimos conhecimentos por meio de observações, imitações e também por meio de "participação guiada", ou seja, interação com membros mais habilidosos do nosso grupo. Também, adquirimos conhecimentos através da interação com objetos. A aprendizagem baseada nos objetos em museus tem mais em comum com uma aprendizagem situada socialmente do que com conhecimentos adquiridos na escola.

Os contextos das exposições em museus são contextos planejados para que os objetos promovam compreensão e aprendizagem (BORUN, 2002). Para a autora, a chave para a compreensão de conceitos em museus é que há crianças, jovens e adultos engajados em novas experiências de aprendizagem e, para tal, as exposições em museus são consideradas como excelentes ocasiões para a troca de informações entre os membros de um grupo.

Borun (2002) acrescenta, ainda, que exposições em museus atuam como um catalisador para a estimulação de conversas entre grupos de visitantes. Desse modo, os objetos estimulam diálogos envolvendo observações, lembranças, associações e conexões ao conhecimento prévio entre os grupos de visitantes. Assim, para ela, num museu, todos os envolvidos numa visita atuam como aprendizes.

Objetos e textos associados a eles podem produzir um avanço na percepção que leva as pessoas a novas compreensões. A interação direta com objetos permite 
Ana Maria Senac Figueroa

OS OBJETOS NOS MUSEUS DE CIÊNCIAS:

o papel dos modelos pedagógicos na aprendizagem

uma aprendizagem visual que pode ser mais rica e mais completa do que só a leitura de um texto, por exemplo. Assim, Borun destaca que,

[‥] os textos explicativos são necessários para fornecer vocabulário e conceitos por meio dos quais interpretamos as experiências, mas a parte mais memorável das experiências vem das observações e manipulações dos objetos. Este é o poder do museu. (BORUN, 2002, p. 253)

A aprendizagem, portanto, pode ser vista como um processo ativo em que as pessoas podem escolher entre transformar e elaborar uma informação para ampliar ou revisar estruturas cognitivas existentes.

Essa visão de aprendizagem mostra mudanças nas estruturas de certo domínio ou campo, ou seja, passam de ingênuas e iniciais para estruturas mais especializadas (CAREY, 1985; GARDNER, 1991; GENTENER; STEVENS, 1983).

Ensinar, então, não é simplesmente corrigir um entendimento errôneo, visto que envolve um processo de mudança conceitual de estruturas menos sofisticadas para esquemas mais complexos. Essa visão construtivista de aprendizagem tem, portanto, importantes implicações para a comunicação por meio de objetos em ambientes não formais (BORUN, 2002).

Ainda, para Borun (2002), cinco níveis de comportamentos influenciam a aprendizagem diretamente, quais sejam: fazer uma pergunta, comentar ou explicar a exposição, ler o texto explicativo em voz alta e ler em silêncio. Esses comportamentos foram considerados por ela, de acordo com suas pesquisas, indicativos de desempenho de aprendizagem e usados em um de seus estudos. 
Encontros com objetos, sejam eles do ambiente natural ou cultural, inflamam a curiosidade, a imaginação, as memórias e as perguntas. Fornecem, também, uma oportunidade para o diálogo, a investigação e as conversas nas quais os indivíduos fazem profundas conexões, não somente com o mundo ao seu redor, mas com outros indivíduos que estão em frente ao objeto, com os conteúdos que permeiam o objeto e com os pensamentos e experiências de cada um. Assim, essas conexões ou interações entre os indivíduos de um determinado grupo, na presença de objetos, são a base para a aprendizagem e o núcleo do conceito de museu como sendo lugares onde o conhecimento é construído, discutido, refletido e transmitido para futuras gerações.

Se as interações citadas acima forem focalizadas, bem como as maneiras de como os objetos influenciam a aprendizagem, os idealizadores de museus poderão facilitar a experiência do visitante nesses espaços de educação não formal (MORRISSEY, 2002). A autora relata, ainda, que os objetos podem nos levar para uma "viagem", do mundo comum do dia-a-dia para um mundo de desafios e mudanças e, a partir dessa "viagem", voltar para casa uma pessoa diferente daquela que chegou ao museu. Para ela, os objetos nos levam do familiar e conhecido para lugares secretos e distantes, onde ideias são modificadas e para onde várias formas de interpretações nos servem de guia ou orientações.

Morrissey (2002) ressalta, ainda, que os artefatos estão vivos, que cada um tem uma voz e, que eles nos lembram do que significa sermos humanos. Objetos, como também espécimes coletados do ambiente natural, representam e codificam tudo o que os humanos têm vivido; eles são lembretes ou registros de crenças, valores, lugares, atividades e tempos. Todavia, ela acrescenta que assim como a 
Ana Maria Senac Figueroa

OS OBJETOS NOS MUSEUS DE CIÊNCIAS:

o papel dos modelos pedagógicos na aprendizagem

linguagem, o objeto é subjetivo e depende de significados de outros atributos, mas enfatiza que é ele que faz o elo com os outros atributos.

Para Morrissey (2002),

[...] o valor de um objeto não está somente na sua idade ou beleza, mas na habilidade em iluminar uma parte da experiência humana, para fornecer um portal por meio do qual as pessoas podem ver as suas experiências no contexto de sua história e cultura. O poder de um objeto, para a autora, reside na linguagem que ele fala e o que ela provoca nos visitantes. (MORRISSEY, 2002, p. 286)

As interações com os objetos envolvem observação, descrição, conhecimento prévio, discussão, criação e testagem de hipóteses, e vão ao encontro das evidências, imaginação, elaboração de questões e até mesmo da leitura de etiquetas - processos que são partes do conhecimento e da aprendizagem.

Morrissey (2002) admite que expressar os processos do pensamento e compartilhar as mudanças intelectuais com outras pessoas frente a um objeto pode promover uma oportunidade para adultos e crianças compreenderem como outras pessoas pensam, como lidam com as situações do mundo e o que eles valorizam. Com isso, aprendem novas maneiras de pensar sobre o mundo e sobre as pessoas.

Afinados com os estudos e com as ideias dos diferentes autores que citamos nesse tópico da pesquisa, apresentaremos, a seguir, os motivos da opção por uma pesquisa qualitativa e os instrumentos de coleta de dados utilizados, bem como uma detalhada apresentação do museu escolhido, o Museu de Ciências Naturais da PUC-Minas.

Apresentaremos, ainda, o modelo do esqueleto da preguiça gigante, objeto de nosso estudo, inserindo, nessa apresentação, um pouco da história de como o 
Ana Maria Senac Figueroa

OS OBJETOS NOS MUSEUS DE CIÊNCIAS:

o papel dos modelos pedagógicos na aprendizagem

seu original foi encontrado, bem como as intenções dos elaboradores em colocá-lo no conjunto expositivo à que pertence e está exposto.

As características dos sujeitos envolvidos na pesquisa também serão explicitadas no próximo capítulo. 
METODOLOGIA DA PESQUISA 


\section{METODOLOGIA DA PESQUISA}

\subsection{A OPÇÃO PELA PESQUISA QUALITATIVA}

Para apreensão do objeto de estudo, que tem por objetivo geral caracterizar o papel pedagógico dos objetos/modelos nos museus de ciências, na perspectiva da aprendizagem em museus, pretendemos seguir um desenho de pesquisa qualitativa desenvolvido no âmbito de museus de ciências. Essa opção justifica-se tanto para compreender o processo das intenções do objeto/modelo exposto no museu, quanto para compreender as interações dos jovens, selecionados para esse estudo, com o objeto pedagógico escolhido, o modelo do esqueleto da preguiça gigante.

A pesquisa qualitativa emergiu do investimento da antropologia e da sociologia com a intenção de delimitar melhor seu objeto de estudo e a necessidade de rever alguns princípios e procedimentos de investigação, a fim de propor orientações mais adequadas para a apropriação de metodologias que legitimassem o "fazer ciência" na investigação dos fenômenos sociais (MARTINS, 2004). Pautada até as décadas de 1960 e 1970 nos mesmos pressupostos das ciências naturais, em que dominavam as questões de mensuração, variáveis, testes de hipóteses e estatística, a busca por outro referencial trazia a possibilidade de apreender a complexidade dos fenômenos sociais nas suas diferentes faces e interações (MARANDINO et al., 2009).

No que se refere às pesquisas em educação em museus, novas adaptações da abordagem qualitativa têm sido feitas. Pode-se afirmar que muitas justificativas, 
assim como as temáticas e procedimentos utilizados no campo educacional escolar, estão sendo usadas também para estudar o fenômeno educacional no âmbito dos museus. Certamente, essas aproximações geram possibilidades importantes de investigação e desafios específicos, relativos às diferenças entre os dois contextos educacionais - escola e museu - que merecem ser mais bem aprofundados.

No âmbito das pesquisas em educação nos museus, metodologias quantitativas e qualitativas se fazem presentes. Enquanto as metodologias quantitativas se voltam à avaliação de resultados obtidos pelo museu (número de visitantes, estatísticas de uso e ocupação dos espaços, avaliações da compreensão de temas pelos visitantes após as visitas, entre outros), a pesquisa qualitativa permite a compreensão dos processos envolvidos na experiência museal.

Parte da pesquisa educacional realizada nos museus pode ser vista dentro do que é chamado de "estudos de público". Como indicam Studart et al. (2003), os estudos de público englobam tanto as pesquisas de "avaliação" quanto as de "investigação" e são realizados por meio de instrumentos metodológicos como entrevistas, observações, painéis (focus groups) e questionários. Objetivam, de maneira geral, ajudar na tomada de decisões, na melhoria das relações com o público, além de indicarem o que os visitantes pensam e como eles se comportam no museu (RUIZ, 2005; STUDART et al., 2003).

De acordo ainda com os autores acima citados, diferentes temas são abordados nos estudos de público que, em geral, referem-se ao perfil dos visitantes e às enquetes sobre o uso pelos indivíduos das instituições culturais. Ressaltam ainda o comportamento e as interações sociais nos museus, a aprendizagem e as relações entre educação formal e não formal nesses espaços e a experiência 
museal. Segundo os autores, algumas pesquisas investigam vários aspectos em um mesmo estudo.

Hooper-Greenhill (1998), ao estudar a prática dos trabalhos de avaliação na década de 1970, observou que as exposições foram o alvo privilegiado das investigações realizadas nesse período. Fundamentadas na psicologia behaviorista, que buscava estudar o comportamento dos indivíduos com base nas condutas visíveis apresentadas, essas pesquisas quantificaram o comportamento dos visitantes no intuito de medir o alcance dos objetivos das exposições. Para a referida autora, esses estudos apresentavam os dados de maneira parcial, pois a observação poderia indicar o que os visitantes estavam fazendo, mas não revelava o porquê de tal conduta. A forma de interação com a exposição era imaginada a partir de uma única perspectiva, na qual cabia aos visitantes o papel de assimilar as informações disponíveis.

À medida que outras exposições foram realizadas, e que pouco a pouco se incorporou à perspectiva dos visitantes, a atenção dos processos de avaliação deixou de focalizar apenas a estrutura das mostras para se dirigir também às necessidades do público. Para Hooper-Greenhill (1998) o foco das investigações voltou-se para os aspectos cognitivos e afetivos da experiência da visita ao museu, sendo introduzida a noção da não existência de um grupo homogêneo de indivíduos que frequentam tais espaços.

No Brasil, as pesquisas com foco na educação em museus de ciências se ampliam a partir dos anos 1990. Em parte associada a um dos momentos de proliferação de novos museus de ciências no país (STUDART et al., 2003), ocorre a intensificação da produção a partir dessa temática. São produzidos trabalhos de 
Ana Maria Senac Figueroa

OS OBJETOS NOS MUSEUS DE CIÊNCIAS:

o papel dos modelos pedagógicos na aprendizagem

mestrado e doutorado que possuem, como universo de pesquisa, os museus de ciências.

laninni et al. (2007) identificaram alguns aspectos sobre as instituições que produzem pesquisas nessas áreas. A maioria dos pesquisadores é filiada a universidades (faculdades, departamentos e núcleos de pesquisa) e museus e espaços afins, indicando o crescimento ou fortalecimento dessas instituições, como geradoras de conhecimento nessas áreas. Quanto à distribuição dessas instituições por regiões no país, o estudo afirma que essa ocorre de forma polarizada, sendo que a maioria dos pesquisadores (65\%) localiza-se nos estados de São Paulo e Rio de Janeiro, apesar de ser possível encontrar pesquisadores atuando em todas as regiões do país.

Com relação às abordagens metodológicas das pesquisas em educação em museus no Brasil, encontram-se investigações que trabalham tanto com abordagens metodológicas quantitativas quanto qualitativas, ou ainda que buscam articular ambas as perspectivas (MARANDINO, 2006).

A categoria de pesquisa qualitativa implica, entre outros elementos, uma etapa inicial de estudo sobre a literatura existente dentro do tema a ser investigado e sobre o contexto onde será desenvolvido, o que auxiliará na construção do "olhar" teórico e na "formulação de problemas" e na "orientação da própria pesquisa" (DAUSTER, 1989).

O surgimento da abordagem qualitativa como alternativa metodológica de pesquisa advém da insustentabilidade de uma concepção de ciência baseada em "regras inquestionáveis", reduzindo os fatos (sociais e naturais) às suas dimensões 
observáveis e mensuráveis. Esta visão de mundo está presente no paradigma da ciência moderna, em que a natureza pode ser reduzida a um modelo de conhecimento universalmente válido (SANTOS, 1988).

Com base nos pressupostos apontados, o estudo em questão se insere na abordagem qualitativa de pesquisa, uma vez que pretendemos compreender o potencial pedagógico dos modelos nos museus de ciências. Em geral, o plano de trabalho da pesquisa qualitativa é aberto e flexível e os focos de investigação passam por uma constante revisão. Alves-Mazzotti (2002) reafirma esse ponto de vista, indicando que as pesquisas qualitativas, por sua diversidade e flexibilidade, não admitem regras precisas. No entanto, essa autora aponta argumentos favoráveis e contrários, a partir da bibliografia na área, para a defesa de um mínimo ou de um grau maior de estruturação.

O plano de trabalho que apresentamos parte do pressuposto de que essa estruturação deve estar a serviço dos objetivos e finalidades da pesquisa, observando seu caráter qualitativo e, por essa razão, deixando espaço para a compreensão da complexidade da realidade que se quer conhecer, mas procurando também, através da estruturação, a profundidade do estudo. Assim, uma problematização do que se refere uma pesquisa em termos de se caracterizar o papel pedagógico dos objetos expostos nos museus de ciências se faz necessária no momento:

1. Qual a influência do modelo pedagógico do museu na aprendizagem?

2. Até que ponto as intenções do modelo pedagógico são incorporadas nos modelos produzidos pelos jovens pesquisados? 


\subsection{O UNIVERSO DA PESQUISA}

\subsubsection{O Museu de Ciências Naturais da PUC-Minas}

Como já afirmado anteriormente, o objeto de estudo desta pesquisa é a de caracterizar o papel pedagógico dos objetos/modelos nos museus de ciências, bem como a de compreender o processo das intenções do objeto/modelo exposto no museu, e as interações dos jovens, selecionados para esse estudo, com o objeto pedagógico do museu de ciências selecionado. Para tal, optamos por fazer a investigação no Museu de Ciências Naturais da PUC-Minas (FIG. 1), localizado na cidade de Belo Horizonte, Minas Gerais.

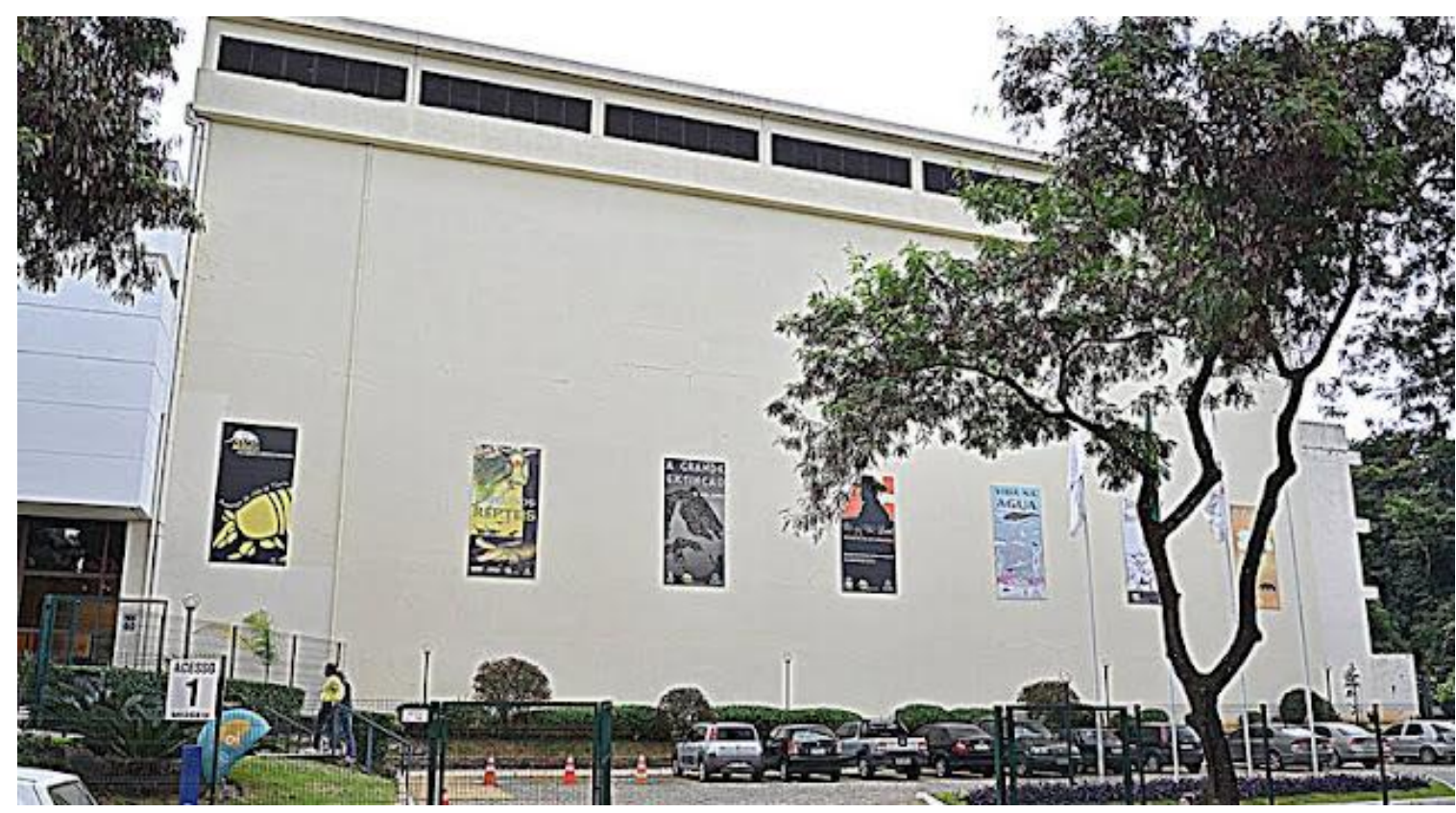

FIGURA 1: Museu de Ciências Naturais da PUC-Minas.

Fonte: Acervo da Pesquisadora.

O Museu de Ciências Naturais escolhido é um museu universitário, que faz parte da PUC-Minas e que tem como missão promover o interesse dos visitantes 
pelas ciências naturais, por meio de exposições, educação e pesquisa. Preservar o patrimônio natural, histórico e cultural do Brasil é objetivo desse museu.

Criado em 1983, o Museu de Ciências Naturais da PUC-Minas desenvolve atividades científicas, educativas e culturais. É um espaço interdisciplinar da universidade, que complementa sua extensão de serviços à comunidade.

No acervo do Museu de Ciências Naturais encontra-se uma das principais coleções de mamíferos fósseis da América do Sul, além de coleções da atual fauna brasileira de mamíferos, aves, répteis e anfíbios, com especial destaque para as espécies do cerrado.

A equipe do Museu de Ciências Naturais desenvolve pesquisas nas áreas de paleontologia, zoologia e conservação da natureza. O espaço do museu é dividido em várias exposições de longa duração, tais como:

\section{Exposição $01 \Rightarrow$ A Era dos Répteis}

Os répteis dominaram a Terra no Mesozóico, durante aproximadamente 150 milhões de anos. Esta exposição apresenta cinco exemplares de dinossauros sulamericanos, pterossauros (répteis voadores) e um grande crocodilo, descobertos no Brasil e em diferentes partes do mundo (FIG. 2). 


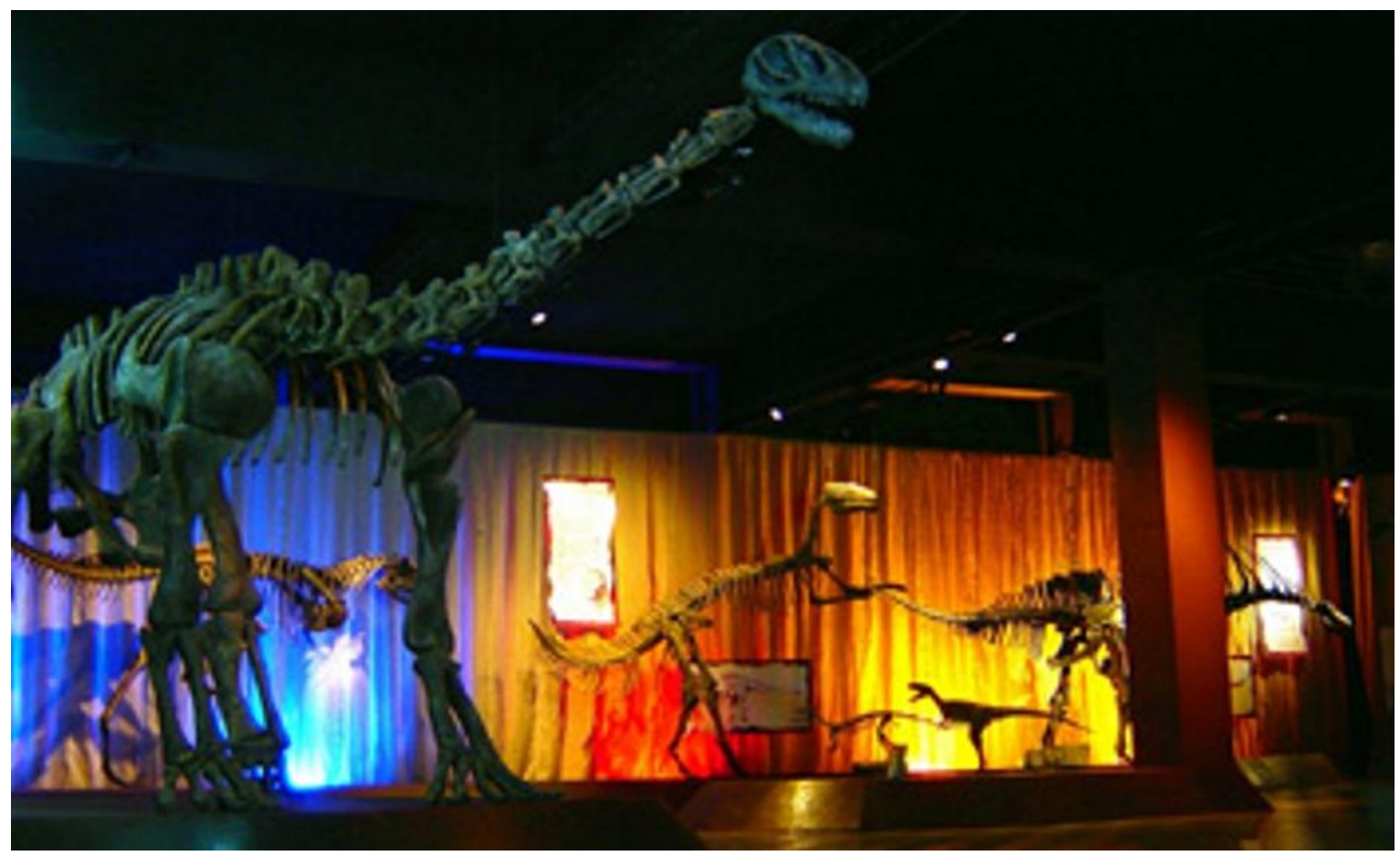

FIGURA 2: Exposição “A Era dos Répteis".

Fonte: Disponível em: <http://www.pucminas.br/museu/index_padrao.php?pagina=216>

\section{Exposição $02 \Rightarrow$ Peter W. Lund: Memórias de um Naturalista}

Uma homenagem aos naturalistas que estudaram o nosso país, em especial a Peter W. Lund (FIG. 3), que fez grandes descobertas em Minas Gerais, no século XIX. Um dos destaques da exposição é a Luzia, um dos mais antigos registros de humanos já encontrados nas Américas. 


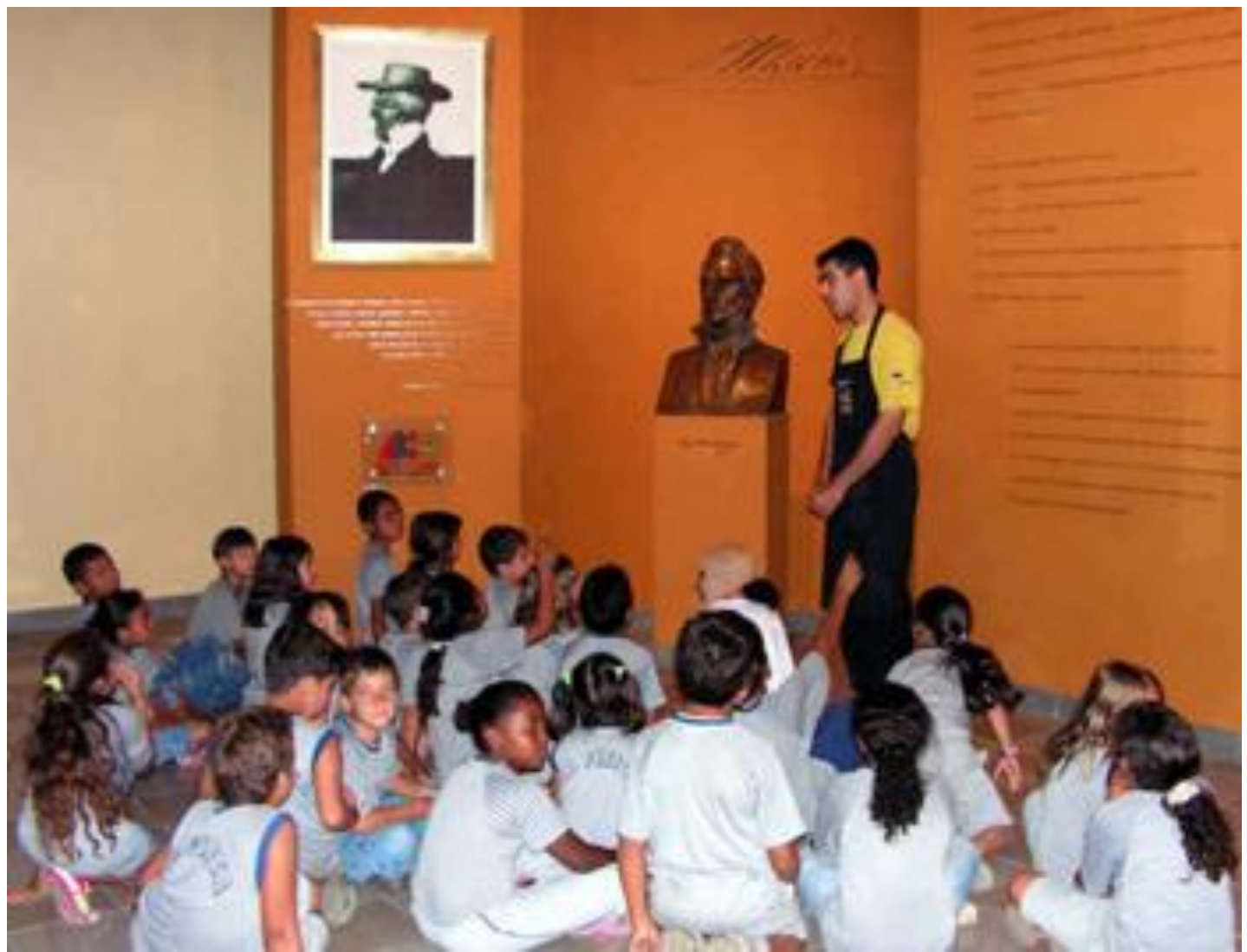

FIGURA 3: Exposição "Peter W. Lund: Memórias de um Naturalista".

Fonte: Disponível em: <http://www.pucminas.br/museu/index_padrao.php?pagina=216>.

\section{Exposição 03 - Cavernas: Espaços Subterrâneos de Vida}

O visitante vivencia a experiência de percorrer o interior da réplica de uma caverna de origem calcária, e conhece aspectos de sua formação, evolução, relações com a fauna e a vegetação, além de processos de fossilização (FIG. 4). 


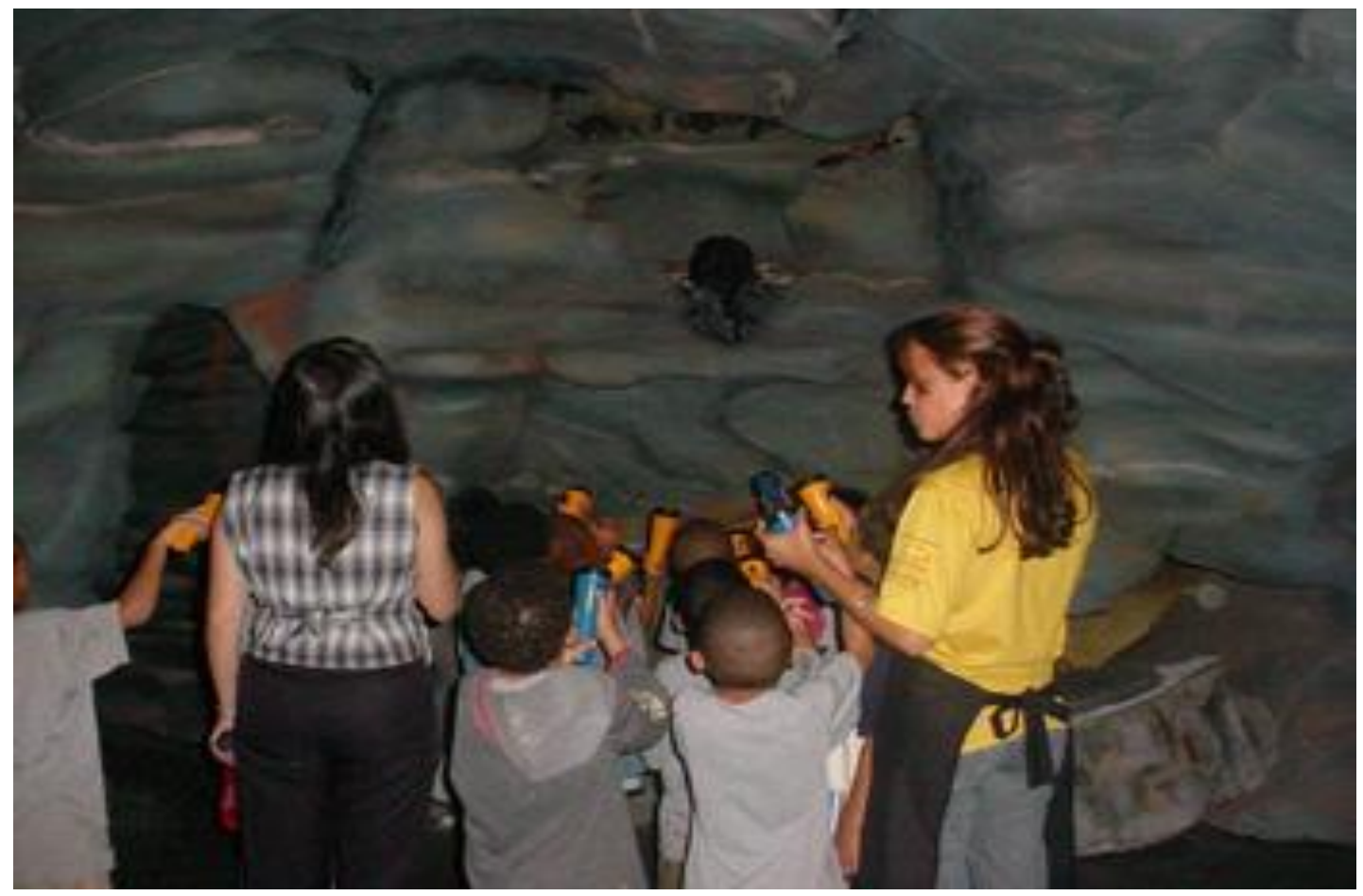

FIGURA 4: Exposição Cavernas: Espaços Subterrâneos de Vida

Fonte: Disponível em: <http://www.pucminas.br/museu/index_padrao.php?pagina=216>.

\section{Exposição $04 \Rightarrow 0$ Cerrado}

A exposição tem quatro módulos: o amanhecer, o dia, o crepúsculo e a noite, onde são apresentados animais e plantas dos diferentes ambientes do cerrado. É uma exposição de imersão, onde o visitante entra nos ambientes e faz suas descobertas de maneira interativa (FIG. 5). 


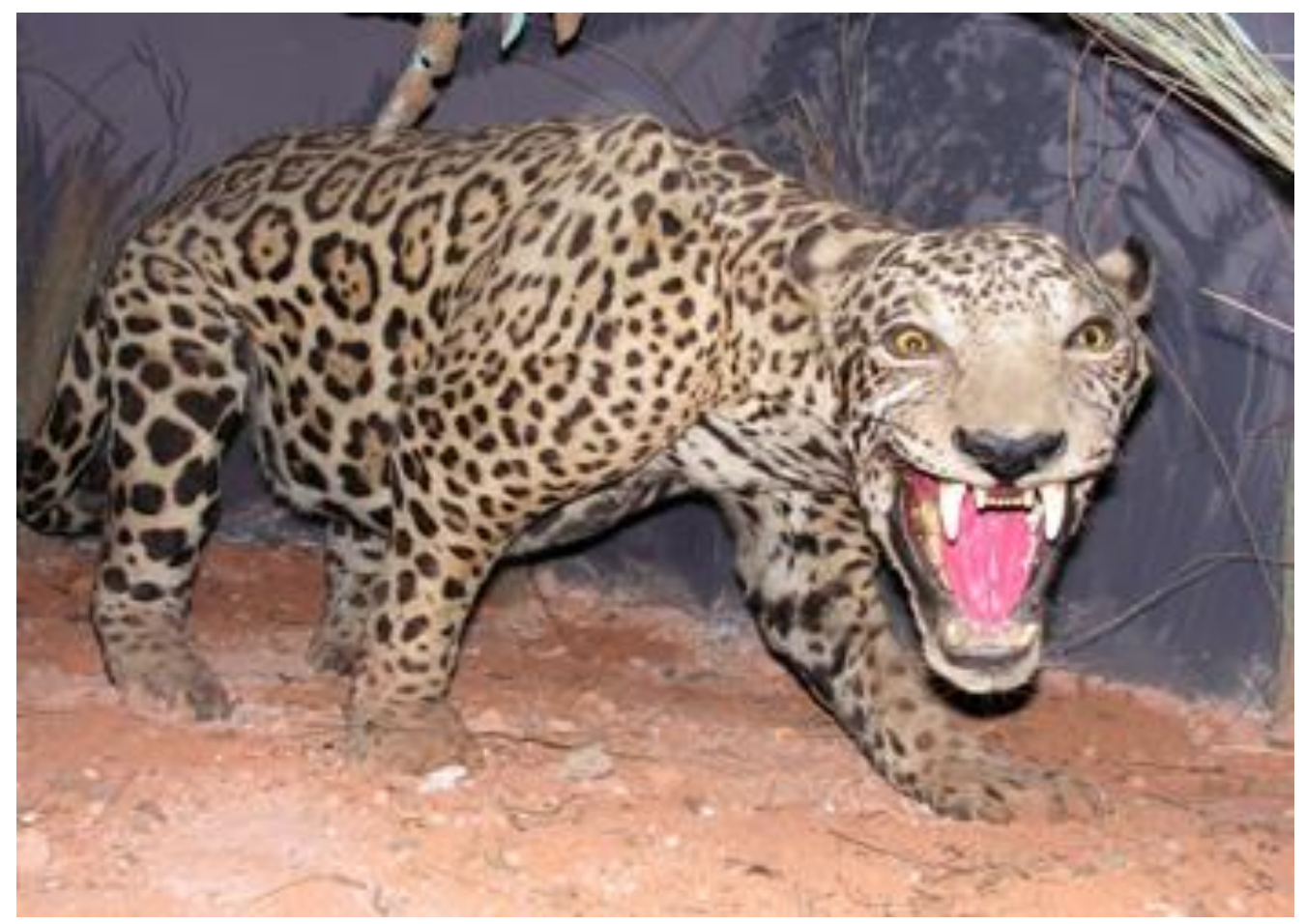

FIGURA 5: Exposição "O Cerrado".

Fonte: Disponível em: <http://www.pucminas.br/museu/index_padrao.php?pagina=216>.

\section{Exposição $05 \Rightarrow$ A Grande Extinção: 11 mil anos}

Esta exposição apresenta um panorama da fauna brasileira do período Pleistoceno, por meio do acervo inédito de animais já extintos e de espécies atuais que também viveram neste período (FIG. 6). Estão expostos esqueletos completos de fósseis como preguiças gigantes, tatu gigante, mastodonte, toxodonte, tigredente-de-sabre, macaco Protopithecus, bem como espécies atuais de tatus e tamanduás. 


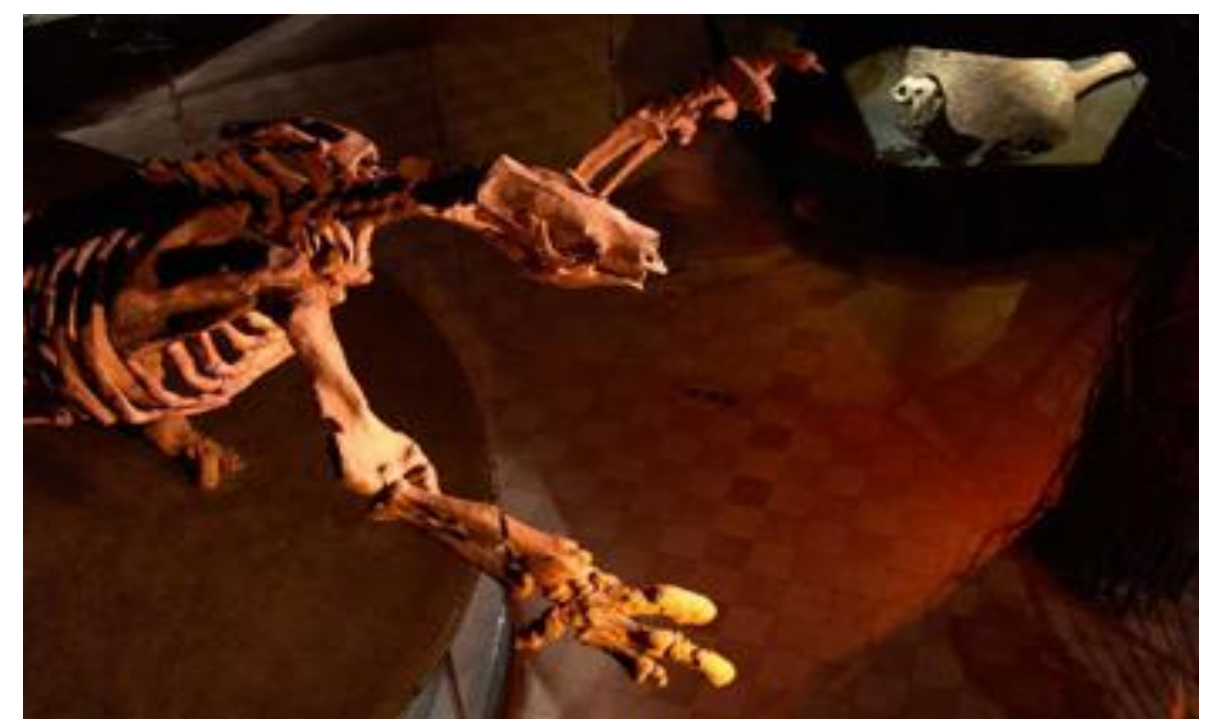

FIGURA 6: Exposição: A Grande Extinção: 11 mil anos

Fonte: Disponível em: <http://www.pucminas.br/museu/index_padrao.php?pagina=216>.

\section{Exposição 06 - Fauna Exótica}

Os animais que não ocorrem no Brasil são o tema dessa exposição (FIG. 7), como por exemplo, elefantes (africano e asiático), rinoceronte e antílopes.

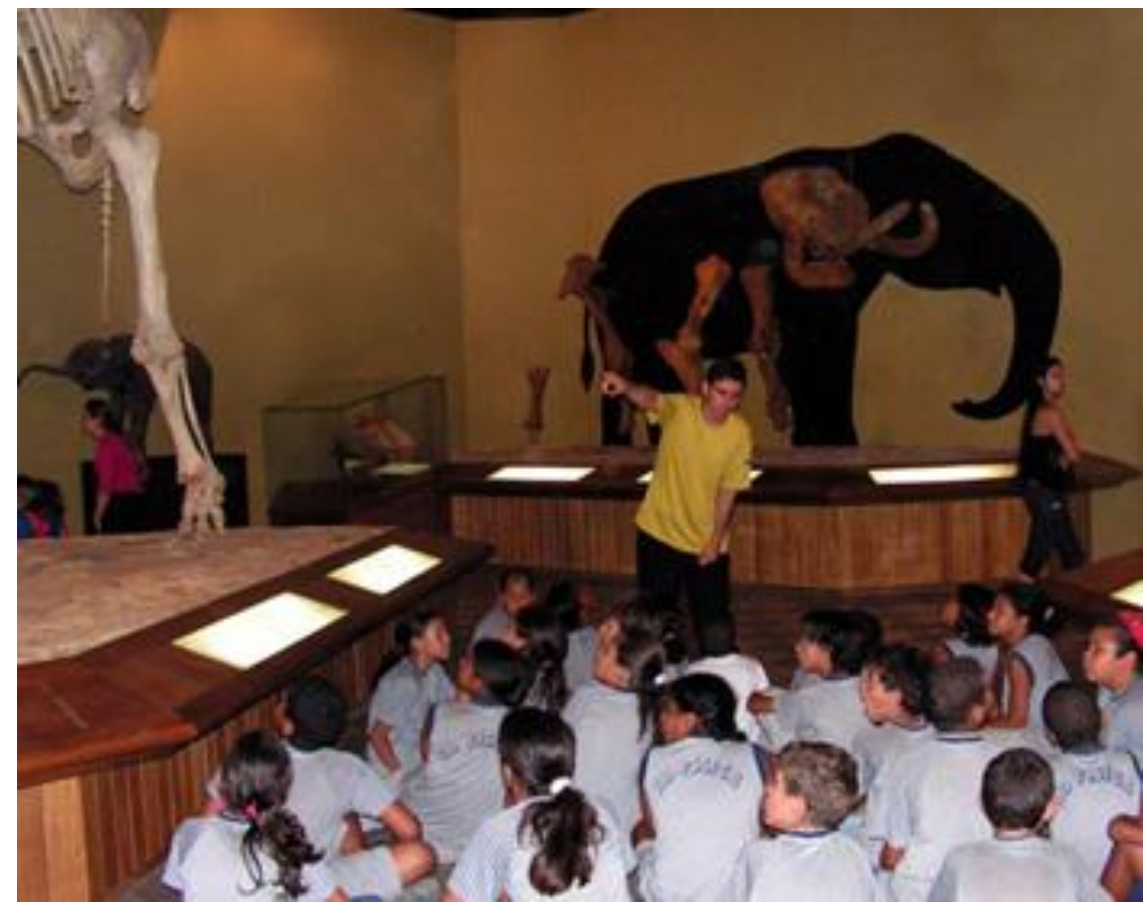

\section{FIGURA 7: Exposição "Fauna Exótica".}

Fonte: Disponível em: <http://www.pucminas.br/museu/index_padrao.php?pagina=216>. 


\section{Exposição 07 - Vida na Água}

O tema desta exposição é a diversidade da fauna do meio aquático (FIG. 8). Ela mostra desde as formas mais primitivas, como os invertebrados, até os seres mais complexos, como as baleias e golfinhos. A exposição traz ainda uma coleção de conchas de moluscos de diversas partes do mundo - cerca de 1.000 exemplares de todos os tamanhos, formas e cores.

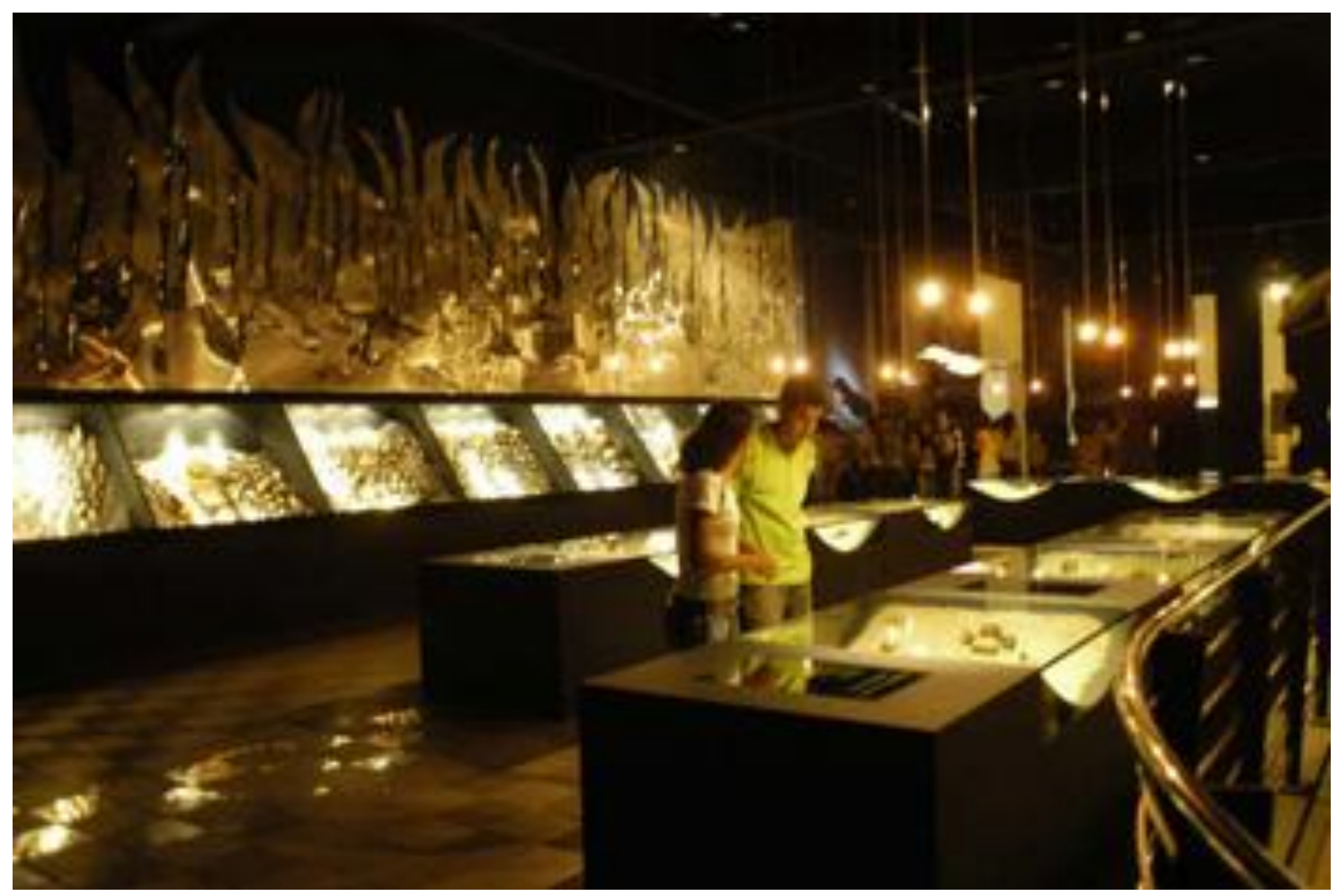

FIGURA 8: Exposição "Vida na Água"

Fonte: Disponível em: <http://www.pucminas.br/museu/index_padrao.php?pagina=216>.

A escolha do Museu de Ciências Naturais da PUC-Minas ocorreu por apresentar uma variedade muito grande de modelos/réplicas de esqueletos de animais já extintos. Além disso, é um dos poucos museus de ciências brasileiros, especializado na elaboração de modelos/objetos pedagógicos, a partir de fósseis originais. Suas atividades estão voltadas para aprendizagem de conceitos e 
Ana Maria Senac Figueroa

OS OBJETOS NOS MUSEUS DE CIÊNCIAS:

o papel dos modelos pedagógicos na aprendizagem

contextos, pertencentes à área das ciências da natureza, pertinentes ao foco do nosso estudo, bem como, com a nossa formação acadêmica.

\subsubsection{O objeto pedagógico: o modelo do esqueleto da preguiça gigante}

No Museu de Ciências Naturais da PUC-Minas, todo o acervo de esqueletos é baseado em modelos/réplicas, que são construídos a partir dos originais. Escolhemos para nosso estudo, o modelo do esqueleto da preguiça gigante, por se tratar do objeto que, por seu tamanho e posição expográfica, mais chama a atenção do público. Além disso, ele tem um papel importante no desenvolvimento de estudos de biologia e de paleontologia, bem como reúne uma gama muito grande de características importantes, fato que o torna adequado para nossa pesquisa. $O$ esqueleto da preguiça gigante está na exposição com a finalidade de apresentar o contexto do grande cerrado mineiro de 11 mil anos. Com esse modelo, particularmente, pretende mostrar aos visitantes a perda dos grandes animais do cerrado mineiro depois da Era Glacial, da última glaciação.

O modelo é exibido desde que a exposição inteira do Pleistoceno foi inaugurada, em sete de abril de 2006. Ele foi construído com os materiais resina e poliuretano.

O objeto que está exposto não é de um molde de ossos fósseis de apenas uma preguiça gigante e sim de ossos de vários espécimes que foram encontrados na Toca das Onças, na cidade de Jacobina, estado da Bahia ${ }^{13}$.

\footnotetext{
${ }^{13}$ As informações a respeito do modelo do esqueleto da preguiça gigante nos foram dadas por funcionários do
} Museu de Ciências Naturais da PUC-Minas. Não há registro escrito dessas informações no referido museu. 
Segundo Lessa et al. (1998), a Toca das Onças é uma pequena cavidade, próxima ao vilarejo conhecido como Caatinga do Moura. Sua entrada vertical, embora de difícil acesso, permitiu o descenso de animais de grande porte. A explicação plausível para uma concentração tão inusitada de restos de tantos animais de grande porte seria a presença de água. Os restos fósseis de Eremotherium laurillardi com adultos, jovens e filhotes num mesmo local, permite a hipótese da queda de um rebanho inteiro lá dentro. O sedimento sobre o qual se encontraram as peças esqueletais, originou em um pequeno curso d'água, já desaparecido. A gruta não tinha outras entradas (CARTELLE; BOHÓRQUEZ ${ }^{14}, 1982$ apud LESSA et al.,1998).

Outras espécies foram coletadas na Toca das Onças, entre elas Pampatherium paulacoitoi (tatu gigante) (CARTELLE ${ }^{15}, 1985$ apud LESSA et al., 1998), Smilodon populator (tigre dente-de-sabre) (CARTELLE; ABUHID ${ }^{16}, 1989$ apud LESSA et al., 1998), dentre outras (LESSA et al., 1998).

$\mathrm{Na}$ exposição, o público pode visualizar o esqueleto da preguiça gigante no tamanho original. A intenção desse objeto em particular é a de mostrar que esse grande animal também tem um contexto de mudança ambiental. Nesse sentido, os nossos dados irão levar em conta o conjunto expositivo, que está detalhado no Capítulo 05 - As intenções do modelo e as interações dos jovens.

\footnotetext{
${ }^{14}$ CARTELLE, C.; BORHORQUEZ, G. A. Eremotherium laurillardi Lund, 1842. Parte I - Determinação específica e dimorfismo sexual. Iheringia, v. 7, p. 45-63, 1982.

${ }^{15}$ CARTELLE, C. Pampatherium paulacoutoi, uma nova espécie de tatu gigante da Bahia, Brasil (Edentata, Dasypodidae). Rev. Bras. Zool., v. 2, n. 4, p. 229-254, 1985.

${ }^{16}$ CARTELLE, C.; ABUHID, V. S. Novos espécimes brasileiros de Smilodon populator (Lund, 1842), Carnívora, Machrairodontinae: morfologia e conclusões taxonômicas. In: CONGRESSO BRASILEIRO DE PALEONTOLOGIA, 11.1989. Anais... Curitiba, v. 1, p. 607-620.
} 


\subsubsection{Um pouco da preguiça gigante}

Com cerca de cinco toneladas e aproximadamente seis metros do focinho ao rabo, a preguiça gigante (FIG. 9) tinha garras poderosas e vivia em bandos nas terras brasileiras. Extinta após a Era do Gelo, a preguiça-gigante desperta a curiosidade de todos.

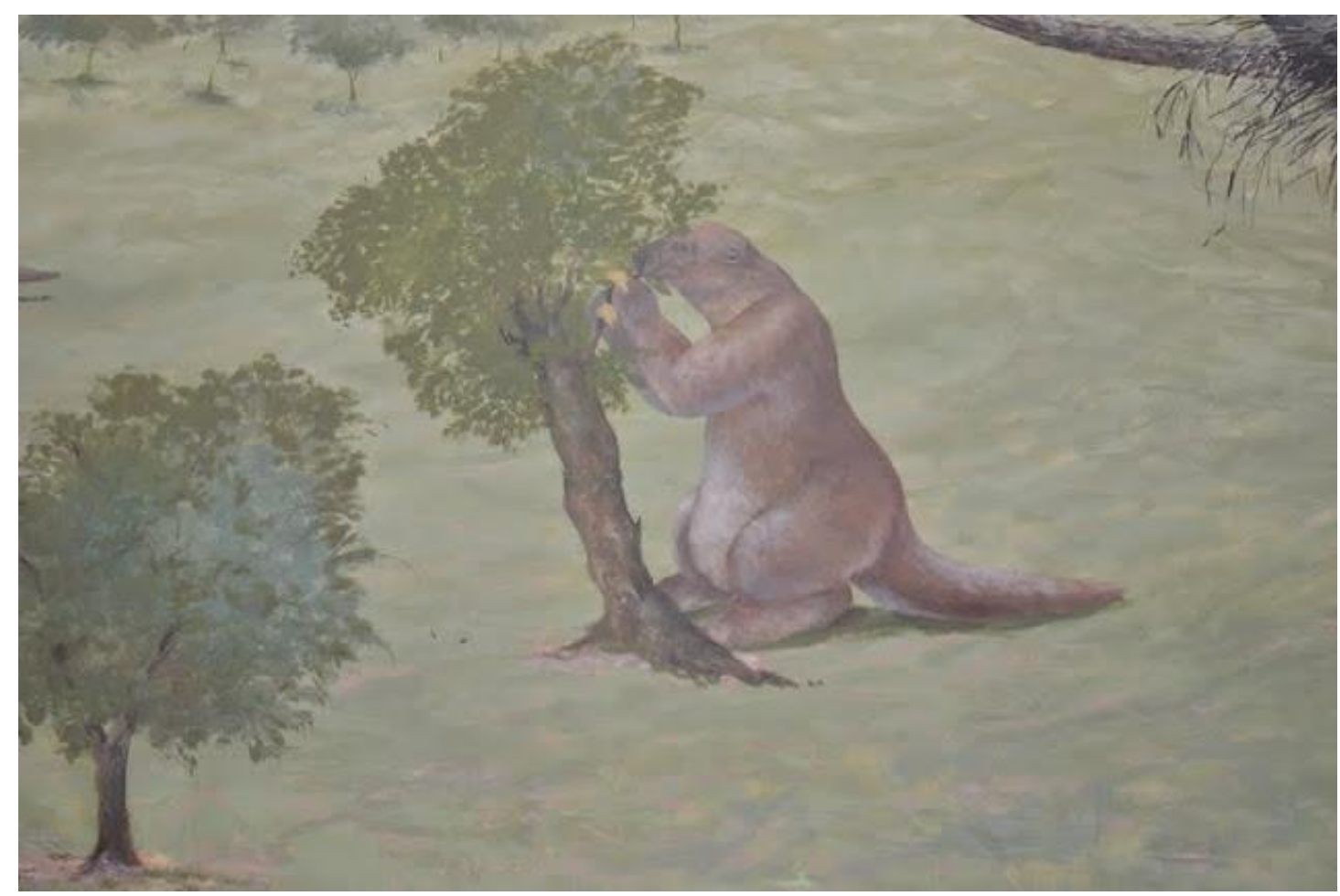

FIGURA 9: Reconstituição da preguiça gigante pintada no painel..

Fonte: Acervo da pesquisadora.

Há milhares de anos, após a última Era do Gelo, viviam em terras brasileiras animais bem maiores do que os que conhecemos hoje. Em nossas matas, campos e cerrados conviviam onças-pintadas, veados, capivaras, tatus gigantes, tigres dentede-sabre e variedades de bichos-preguiça, além de inúmeras outras espécies.

Dentre as preguiças, uma se destacava pelo tamanho descomunal. É por esse motivo que os paleontólogos passaram a chamá-la de preguiça gigante. Pelos 
numerosos registros fósseis desse animal, os cientistas concluíram que a preguiça gigante vivia em grandes bandos e habitava todo o território brasileiro.

Além do tamanho, o animal tinha algumas características singulares. Para andar, apoiava as patas no chão quase que dorsalmente, como fazem hoje as preguiças arborícolas, quando descem ao solo, e também os tamanduás.

As patas tinham garras enormes, tendo a maior cerca de 50 centímetros. Mesmo com armas tão poderosas, a preguiça gigante era um animal herbívoro. Alimentava-se de folhas, ramos e tubérculos. O desgaste dos dentes durante a alimentação era compensado pelo crescimento contínuo. Com um detalhe: os dentes não possuíam esmalte.

Por meio do estudo dos ossos de membros locomotores da preguiça gigante, é possível avaliar a grande força muscular do animal. Não era presa fácil para nenhum predador - nem mesmo para o maior deles, o impressionante tigre dente-de-sabre, assim chamado por ter dois enormes caninos em forma de adaga.

Estima-se que uma preguiça gigante adulta devia pesar algo em torno de cinco toneladas. Qualquer variação na fonte de alimento - devido a uma grande seca, a uma variação de temperatura ou mesmo a uma grande enchente - causaria um impacto capaz de levá-la à morte.

Tão poderosa e ao mesmo tempo frágil, a preguiça gigante foi extinta ao fim de um tempo geológico denominado Pleistoceno, por volta de 11 mil anos atrás, na sequência de efeitos gerados pela última glaciação - a chamada Era do Gelo ${ }^{17}$.

\footnotetext{
17 Disponível em: <http://www.jornal.editoradimensao.com.br/4a_ed/OqueEra.php>. Acesso em: 16 maio 2011.
} 
Ana Maria Senac Figueroa

OS OBJETOS NOS MUSEUS DE CIÊNCIAS:

o papel dos modelos pedagógicos na aprendizagem

\subsubsection{Os sujeitos da pesquisa}

A escolha dos sujeitos da pesquisa seguiu os pressupostos da própria pesquisa qualitativa, que segundo Trivinõs o tamanho da amostra pode ser fixado intencionalmente

[...] considerando uma série de condições (sujeitos que sejam essenciais, segundo 0 ponto de vista do investigador, para 0 esclarecimento do assunto em foco; facilidade para se encontrar com as pessoas; tempo dos indivíduos para as entrevistas, etc.) (TRIVINÕS, 1987, p. 132).

Descreveremos a seguir, os sujeitos escolhidos para este estudo.

\subsubsection{O responsável pela exposição}

Selecionamos para a entrevista, o profissional do museu responsável pela produção dos modelos e elaborador da exposição, já que o objeto de nosso estudo é caracterizar o papel pedagógico dos objetos nos museus de ciências.

O entrevistado ocupa o cargo de biólogo sênior do setor de Paleontologia do Museu de Ciências Naturais da PUC-Minas; está envolvido na confecção dos modelos de fósseis e na elaboração das exposições. Ele também participa das pesquisas desenvolvidas no referido museu.

Para tal, preparamos um roteiro de entrevista aberta (APÊNDICE A), para nortear os rumos do que queríamos compreender acerca do modelo e da exposição. As perguntas ao entrevistado não seguiram a ordem que apresenta o roteiro, por optarmos em deixá-lo descrever livremente suas concepções acerca da exposição e do objeto pedagógico. 
Ana Maria Senac Figueroa

OS OBJETOS NOS MUSEUS DE CIÊNCIAS:

o papel dos modelos pedagógicos na aprendizagem

Chamamos o entrevistado de "Carlos", nome fictício dado a ele, para preservar sua identidade.

\subsubsection{Os jovens}

Convidamos cinco jovens para participar da pesquisa. Todos com 17 anos de idade e cursando $02^{\circ}$ ano do ensino médio, em escolas privadas, localizadas na cidade de Belo Horizonte, Minas Gerais. Eles foram identificados com os nomes fictícios Elisa, João, Marina, Rita e Anita para preservar suas identidades.

Julgamos que a opção por jovens, de um mesmo nível de escolaridade, com afinidades sociais semelhantes e que estabelecem uma relação de amizade, facilitaria a interação social, tornando a visita mais fluida e natural.

Essa opção na seleção de pequenos grupos se deve a aspectos técnicos da prática de registro dos dados pela gravação em áudio e vídeo, já que grupos menores permitem um registro mais acurado do áudio (comunicação verbal), com menor grau de interferência e ruído, comum em espaços amplos, além da maior coesão dos membros do grupo, gerando, assim, dados de maior qualidade técnica.

A escolha do nível de ensino e da idade se justifica, pela proposição de que as pessoas são determinadas por fatores como conhecimento e experiência prévia e, pela própria estrutura do sistema de informação. Assim, refletimos que, se os jovens escolhidos estão no penúltimo ano da educação básica, seus conhecimentos prévios e seu sistema de informação estão mais ampliados do que os de jovens de níveis inferiores de ensino. Dessa forma, são os sujeitos adequados para nossa pesquisa. 


\subsection{INSTRUMENTOS DE COLETA DE DADOS E AS ETAPAS DA PESQUISA COM OS JOVENS}

Para a coleta dos dados da pesquisa, combinamos o uso de múltiplas fontes, com a finalidade de obter as informações necessárias tanto com relação às intenções do objeto pedagógico exposto no museu escolhido, quanto às interações dos jovens em relação a este mesmo objeto. Para tal, aos instrumentos de coleta dos dados coube a função de estabelecer indicadores capazes de apontar os objetivos gerais da pesquisa.

Dessa forma, as observações do modelo e as observações do conjunto expositivo foram realizadas com base nos aspectos teóricos relacionados ao tema.

Elaboramos uma entrevista aberta com o responsável pela exposição (APÊNDICE A) e buscamos no site do Museu de Ciências Naturais da PUC-Minas ${ }^{18}$ todas as informações possíveis acerca do referido museu. Encontramos informações gerais sobre as exposições, propostas do museu, horários de funcionamento e os contatos apropriados para uma primeira inserção na realização da pesquisa.

Para a coleta de dados com os jovens, a pesquisa contou com três etapas, todas elas gravadas em áudio e vídeo, incluindo as entrevistas. São elas:

\footnotetext{
$18<$ http://www.pucminas.br/museu/index_padrao.php>.
} 
Ana Maria Senac Figueroa

OS OBJETOS NOS MUSEUS DE CIÊNCIAS:

o papel dos modelos pedagógicos na aprendizagem

\section{1a etapa: antes da visita}

$\mathrm{Na}$ busca de um instrumento adequado para conhecermos algumas informações importantes dos jovens pesquisados, optamos pela entrevista coletiva semiestruturada.

$\mathrm{Na}$ entrevista semiestruturada, o entrevistado tem a possibilidade de descrever o tema questionado, sem ter de preocupar-se com as respostas e as condições fixadas pelo pesquisador, pois se trata de perguntas semiabertas, em que maior ênfase se dá nas interações. Assim, a premissa básica é de que entrevista não é simplesmente um trabalho de coleta de dados, mas sempre uma situação de interação na qual as informações dadas pelos sujeitos podem ser profundamente afetadas pela natureza de suas relações com o entrevistador (MINAYO, 1993).

Com base nessa premissa, procuramos reunir informações sobre os jovens antes da visita ao museu, para levantarmos aspectos sobre o conhecimento, experiências e possíveis aprendizagens ocorridas nesses espaços.

Logo após a entrevista (APÊNDICE B), iniciamos com eles uma atividade de construção do modelo do objeto pedagógico do museu, escolhido para nossa pesquisa - o esqueleto da preguiça gigante - utilizando para tal, massinha de modelar (APÊNDICE C).

O objetivo da construção do modelo, antes da visita, é o de verificar os conhecimentos prévios que os jovens possuem desse objeto pedagógico. 
Assim que os jovens construíram o modelo do esqueleto da preguiça gigante, em sua concepção inicial, seguimos para a visita ao Museu de Ciências Naturais da PUC-Minas.

\section{2a etapa: durante a visita}

A segunda etapa da pesquisa ocorreu durante a visita ao museu, após os jovens terem modelado o esqueleto da preguiça gigante, como eles a concebiam, ou lembravam

Para que houvesse uma conversa dinâmica e produtiva em torno do objeto escolhido para a pesquisa, julgamos necessário utilizar uma estratégia que pudesse instigar essa conversação. O objetivo dessa conversa entre os jovens, frente ao objeto pedagógico, é o de perceber se eles interagem com o mesmo e como ocorre essa interação.

Para tal, fizemos algumas perguntas a eles durante a visita (APÊNDICE D), com o propósito de suscitar nos jovens algumas falas que poderiam não acontecer se essas perguntas não fossem realizadas.

Assim, para esta etapa da coleta de dados, utilizamos placas de papel sulfite, com perguntas (APÊNDICE D) que julgamos necessárias naquele momento da visita, como forma de instigar a interação dos jovens com o conjunto expositivo em questão.

A visita teve a duração de uma hora e meia e saímos todos para a realização da terceira e última etapa, descrita a seguir. 
Ana Maria Senac Figueroa

OS OBJETOS NOS MUSEUS DE CIÊNCIAS:

o papel dos modelos pedagógicos na aprendizagem

\section{$3^{\mathrm{a}}$ etapa: depois da visita}

Após a visita ao museu e o contato direto com o objeto pedagógico, bem como com o conjunto expositivo, os jovens foram novamente entrevistados (APÊNDICE E). Em seguida, elaboraram, com massinha de modelar, outro modelo do esqueleto da preguiça gigante.

Durante a elaboração do modelo final, os jovens foram instigados a relembrar o que viram acerca do objeto pedagógico, a fim de retirar ou acrescentar elementos do modelo construído antes da visita. Nessa etapa da pesquisa, fomos relembrando com os jovens, oralmente, detalhes do esqueleto da preguiça gigante, que eles mesmos questionaram durante a execução da atividade de modelagem.

Essa elaboração do modelo final do esqueleto da preguiça gigante aconteceu de uma forma mais descontraída e propícia para que pudéssemos observar tanto as falas e os questionamentos levantados pelos jovens, como também, a interação entre eles e o objeto pesquisado.

\subsection{A ANÁLISE DOS DADOS}

A análise dos dados prevê apontar o papel pedagógico dos objetos em exposições de museus e caracterizar o potencial do objeto, foco do nosso estudo. Ainda procuramos identificar aspectos relacionados aos processos de aprendizagem dos sujeitos ao interagir com o objeto em uma exposição. Nesse caminho, direcionamos o estudo para o objeto no museu, como um modelo potencialmente 
pedagógico, visto que ele é parte fundamental do conjunto expositivo no museu estudado.

Dessa forma, dividimos a pesquisa em dois momentos, quais sejam: o das intenções com que o modelo escolhido foi elaborado pelo responsável e a compreensão dos processos de aprendizagem, a partir das interações dos jovens com o conjunto expositivo relacionado ao modelo do esqueleto da preguiça gigante.

Para o segundo momento, o das interações dos jovens com o objeto, buscamos levantar as ideias que os sujeitos selecionados possuíam acerca do objeto antes da visita ao museu, analisar as falas dos sujeitos durante a interação com o conjunto expositivo e, ainda, analisar as interpretações do objeto realizadas pelos sujeitos após a visita ao museu.

Assim sendo, propomos analisar o modelo pedagógico do esqueleto da preguiça gigante e o conjunto expositivo onde está inserido, a partir de dois eixos conceitual e processual - que buscam expressar ambas as dimensões da aprendizagem.

Tomando por base a revisão de literatura realizada por Colinvaux (2005), importa considerar os diferentes conceitos que um objeto expressa, assim como as formas de interação entre os sujeitos mediadas pelo objeto, que parece estar no cerne da experiência em museus.

- Eixo conceitual de aprendizagem: Esse eixo foi construído com base na ideia de que a aprendizagem é mediada por objetos e, especialmente nos museus, os objetos encerram aspectos relacionados à história e o contexto de onde foi coletado, assim como os conhecimentos científicos elaborados 
com base nele (VAN PRÄET, 2003; DIERKING, 2002; HEIN, 2000). No caso da preguiça gigante no Museu Ciências Naturais da PUC-Minas, tais conhecimentos se referem principalmente aos campos da biologia e da paleontologia. Assim sendo, nesse eixo, relacionado aos aspectos conceituais, buscamos destacar tanto nas intenções do objeto e do conjunto expositivo como nas interações dos jovens com esses elementos, os itens relacionados às características biológicas e ecológicas do objeto em estudo e seu contexto geológico. Desse modo, serão analisadas a morfologia, fisiologia, comportamento, hábitos alimentares, locomoção e reprodução do organismo. Da mesma forma, levaremos em conta também os aspectos de sua origem e sobrevivência, da conservação e da preservação da fauna e da flora da época em que viveu a preguiça gigante, bem como as mudanças climáticas que ocorreram no planeta, provocando a perda da diversidade pretérita e futura.

- Eixo Processual de aprendizagem: Nesse eixo serão identificados os modos de interação dos sujeitos com os objetos e entre eles, considerando que esses aspectos são cruciais para compreensão da aprendizagem nos museus (COLINVAUX, 2005; PARIS, 2002; HEIN, 2000). Desse modo, iremos analisar os dados da intenção do objeto e do conjunto expositivo, e da interação dos jovens com esses elementos, buscando evidenciar aspectos do modelo que favorecem a manifestação da curiosidade, motivação, imaginação e a memória. Além disso, centraremos a análise nos dados que podem nos levar a perceber questionamentos sobre o objeto e 0 diálogo e a interação entre sujeitos. Da mesma forma, sob o ponto de vista do processo de investigação, analisaremos se o modelo promove 
observação, descrição, discussão, levantamento e testagem de hipóteses, ou mesmo, a expressão dos conhecimentos prévios. Também serão analisados, tanto do ponto de vista das intenções do modelo quanto das interações dos jovens mediado pelo mesmo, o papel e as relações estabelecidas com os textos e imagens existentes no conjunto expositivo e com o modelo em si, observando características como valor, escala e autenticidade.

Esses dois eixos, que foram utilizados como referência, tanto para analisar as intenções do museu, quanto para analisar as interações dos jovens com o modelo e o conjunto expositivo, antes, durante e depois da visita serão, também, oportunos em nos auxiliar a responder perguntas significativas para esse estudo, quais sejam: qual a influência do modelo pedagógico do museu na aprendizagem? $E$, até que ponto as intenções de um modelo pedagógico são incorporadas nos modelos produzidos pelos jovens?

As intenções do objeto pedagógico selecionado, o conjunto expositivo em que o modelo está inserido, bem como as interações dos cinco jovens, sujeitos da pesquisa, serão apresentados a seguir, na busca de revelar, com a maior precisão possível, os elementos que servirão como fonte de dados para esse estudo. 
AS INTENÇÕES DO MODELO E AS INTERAÇÕES DOS JOVENS 


\section{AS INTENÇÕES DO MODELO E AS INTERAÇÕES DOS JOVENS}

Selecionamos para esse estudo, o modelo do esqueleto da preguiça gigante, por se tratar do objeto que, por seu tamanho e posição expográfica, mais chama a atenção do público. Além disso, ele tem um papel importante no desenvolvimento de estudos de biologia e de paleontologia, bem como reúne uma gama muito grande de conceitos, o que o torna adequado para nossa pesquisa.

O conjunto expositivo onde se encontra inserido o modelo do esqueleto da preguiça gigante, é denominado "A Grande Extinção: 11 mil anos". Este conjunto apresenta um panorama da fauna brasileira do período Pleistoceno, por meio do acervo inédito de animais já extintos e espécies atuais que também viveram no período.

Já os jovens foram selecionados a partir de características que achamos pertinente encontrar, quais sejam, mesma idade (17 anos), escolaridade ( $2^{\circ}$ ano do ensino médio), interação social (são amigos), buscando, assim, um grupo mais homogêneo e coeso de ideias e habilidades cognitivas, que compartilham expectativas próximas com relação ao futuro profissional e pessoal.

Apresentaremos, a seguir, as intenções do modelo pedagógico segundo as nossas observações e as observações levantadas pelo biólogo responsável pela elaboração do modelo e sua presença na exposição. Logo após essa apresentação, descreveremos as interações dos jovens com o modelo do esqueleto da preguiça gigante e de todo o conjunto expositivo em que está inserido. 
Ana Maria Senac Figueroa

OS OBJETOS NOS MUSEUS DE CIÊNCIAS:

o papel dos modelos pedagógicos na aprendizagem

\subsection{AS INTENÇÕES DO MODELO PEDAGÓGICO}

O objeto pedagógico, ou seja, o modelo do esqueleto da preguiça gigante está descrito a seguir e buscamos destacar as intenções que o objeto apresenta na exposição, tanto na perspectiva do nosso olhar, como na perspectiva do olhar do responsável pela exposição no museu.

Como apontamos anteriormente, direcionamos o estudo para o objeto no museu, como um modelo potencialmente pedagógico, visto que ele é parte fundamental do conjunto expositivo em que está inserido, no Museu de Ciências Naturais da PUC-Minas. Para tal, dividimos a pesquisa em dois momentos.

\subsubsection{O Objeto Pedagógico e o Conjunto Expositivo: nosso olhar}

O primeiro impacto que se tem do objeto pedagógico, o esqueleto da preguiça gigante (FIG. 10), é a sua grandeza e altivez. Ele está erguido numa posição bípede, posição esta que utilizava para se alimentar das folhas de grandes árvores. Notamos, ainda, pequenos detalhes nos ossos como ranhuras e até mesmo marcas de terra. 


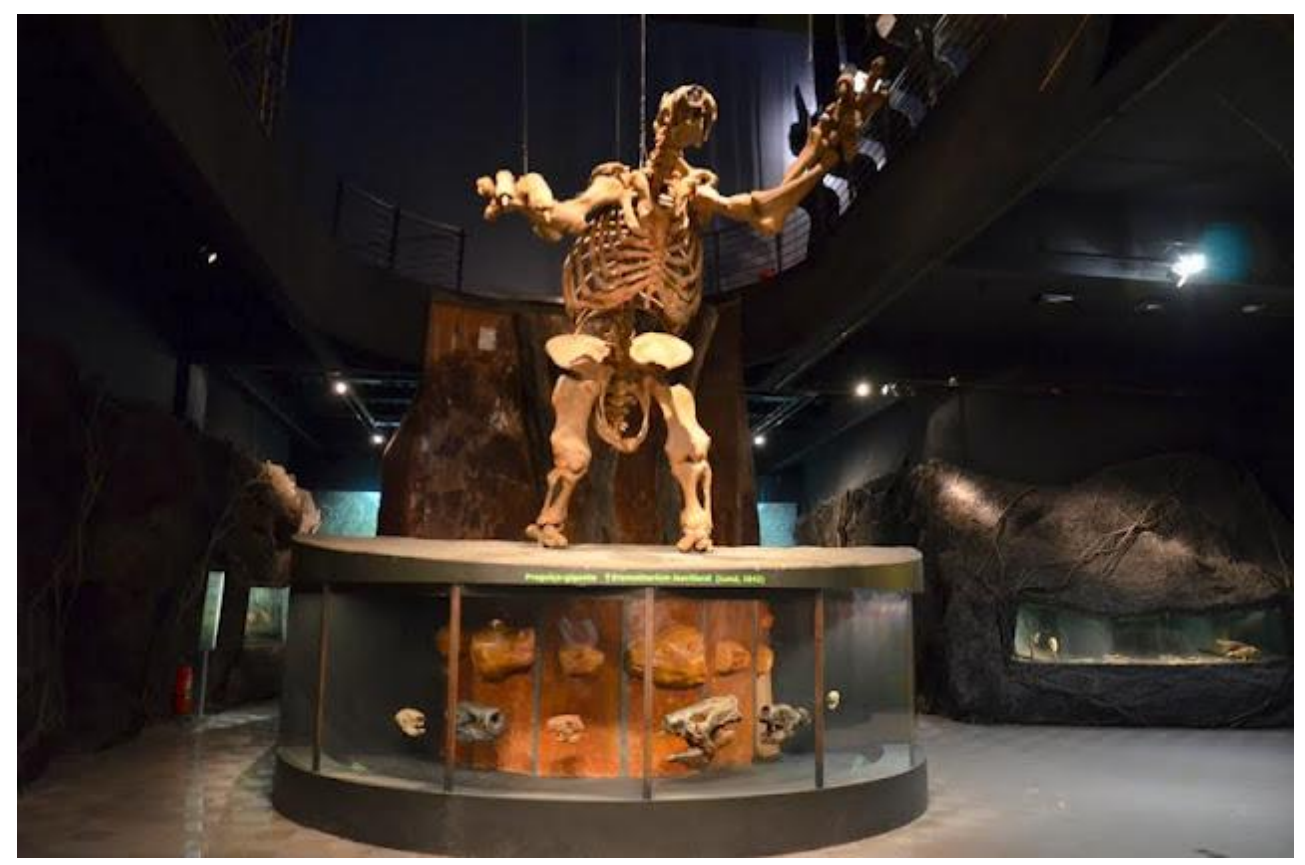

FIGURA 10: Modelo do esqueleto da preguiça gigante.

Fonte: Acervo da pesquisadora.

O modelo é contemplativo e não há nenhum elemento que o explique, a não ser a legenda (FIG. 11 e FIG. 12).

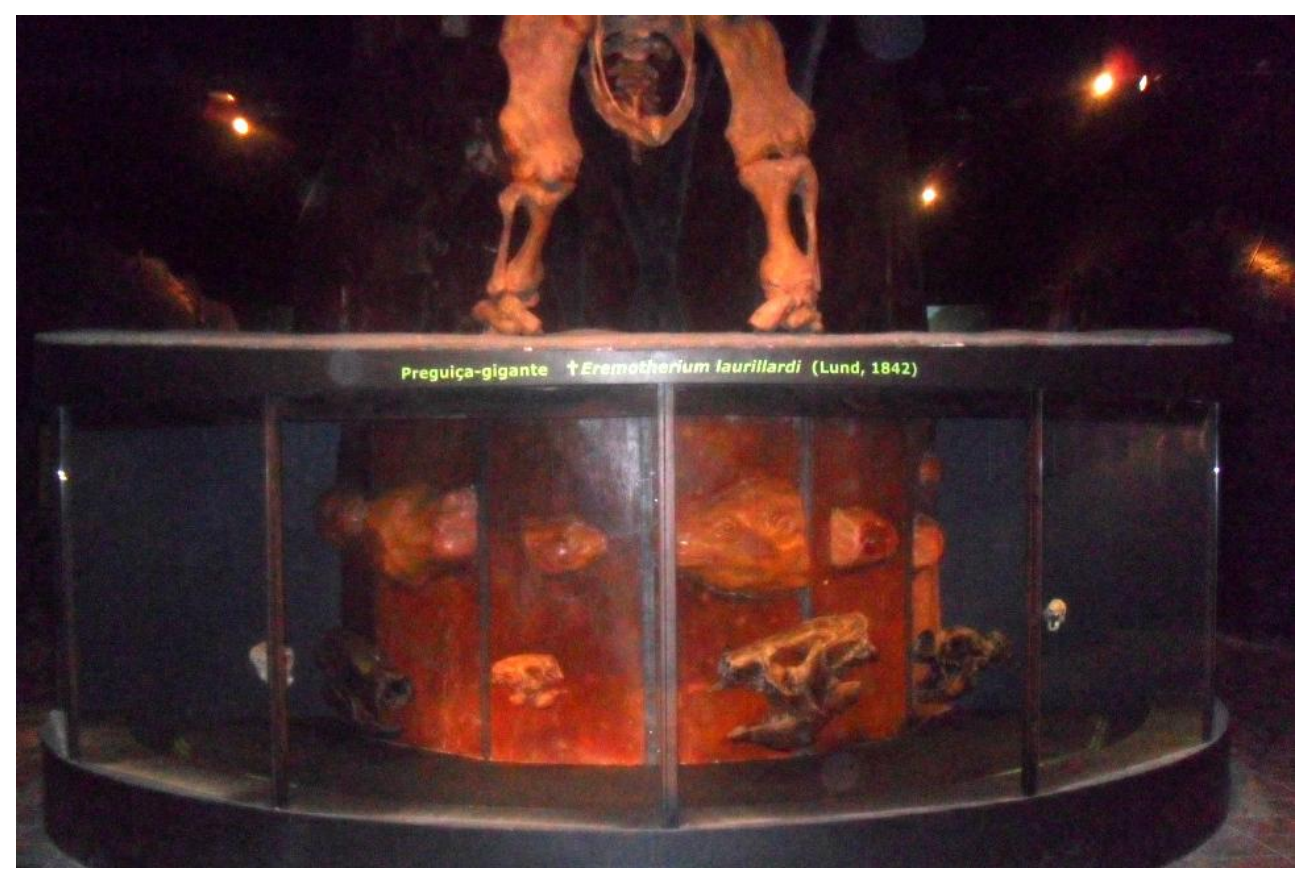

FIGURA 11: Legenda: Preguiça gigante - Eremotherium laurillardi (Lund, 1842). Fonte: Acervo da pesquisadora. 


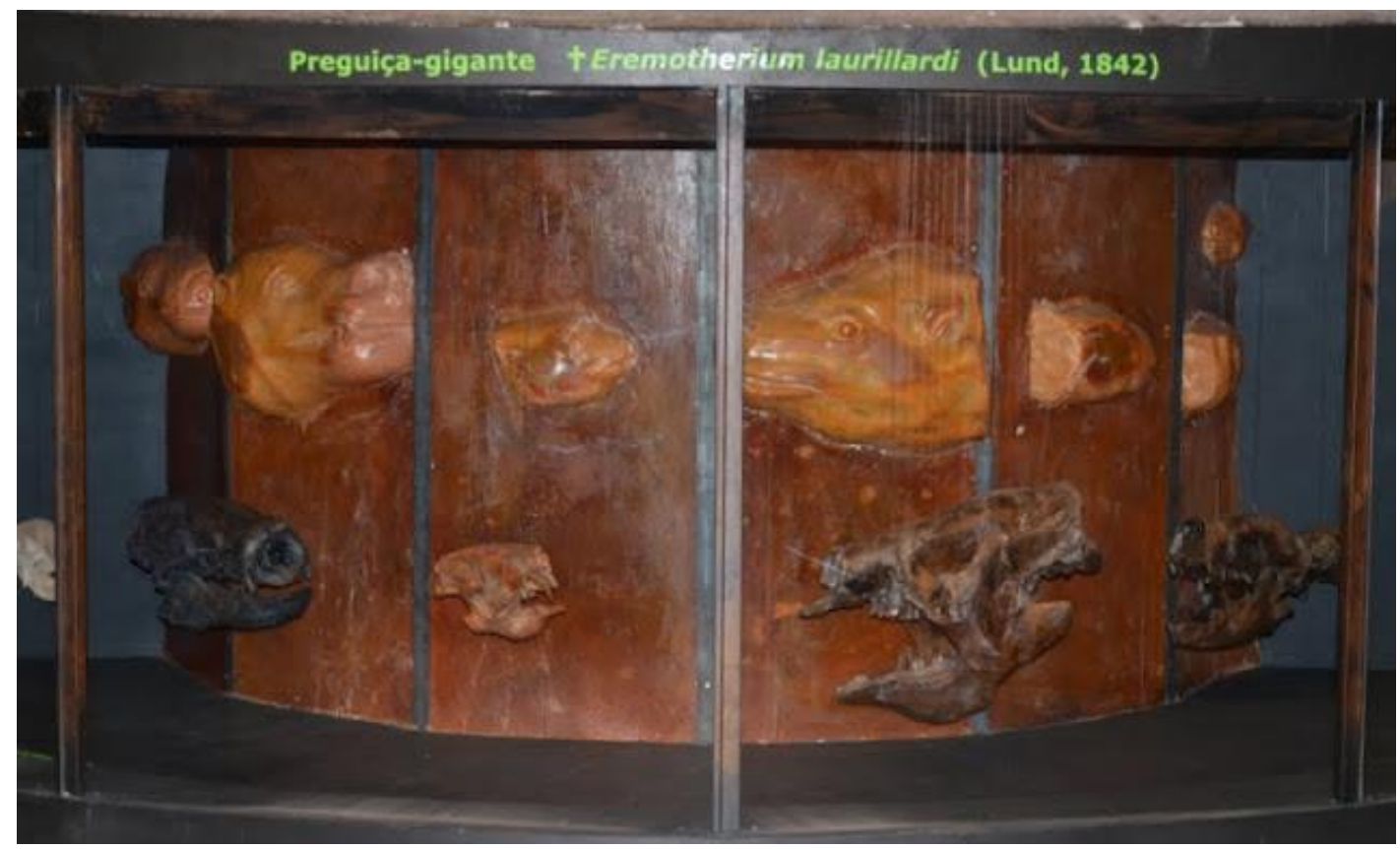

FIGURA 12: Legenda e vitrine com fósseis originais e reconstituições da preguiça gigante.

Fonte: Acervo da pesquisadora.

Está colocado à frente da exposição, com os elementos do conjunto expositivo situados bem atrás dele (FIG. 13).

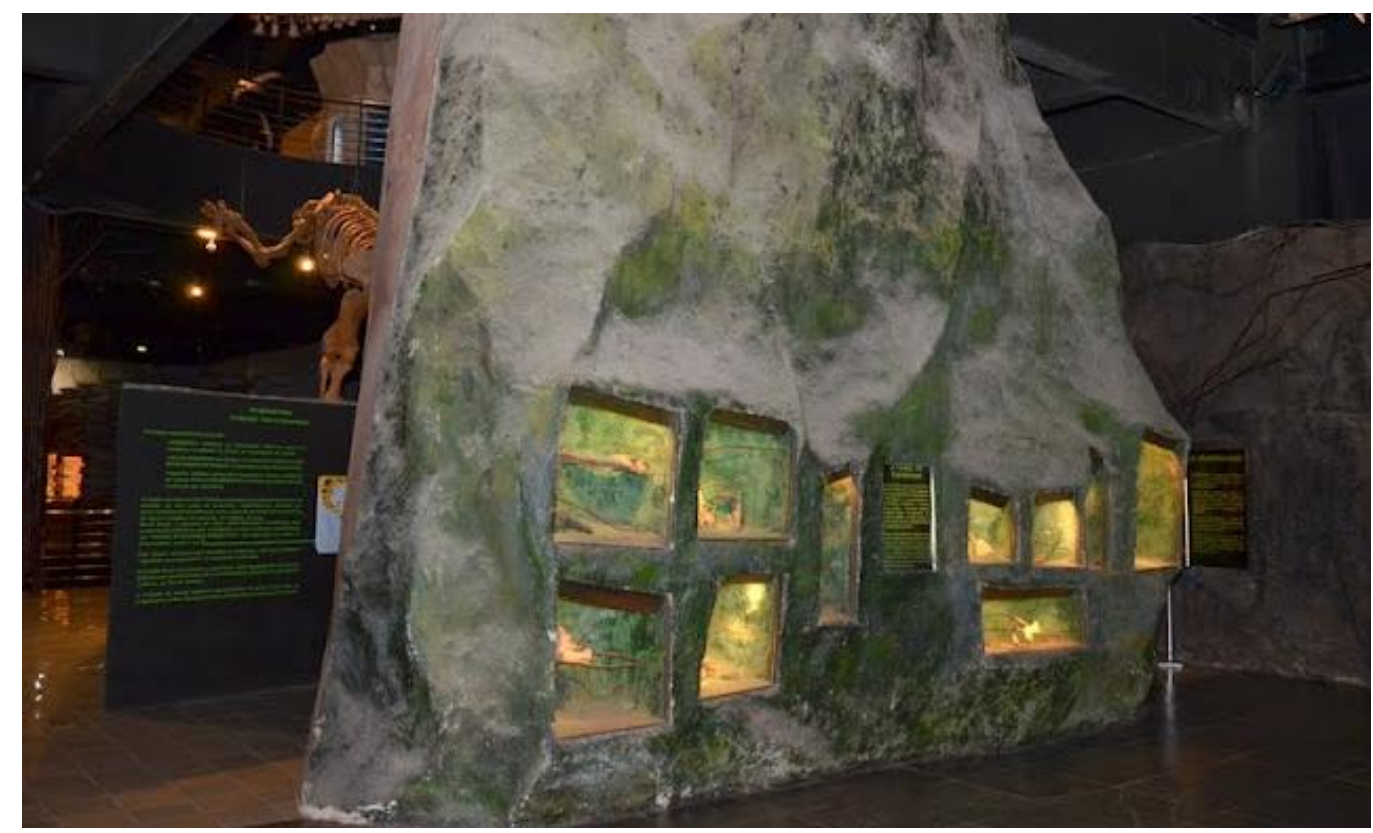

FIGURA 13: Conjunto expositivo.

Fonte: Acervo da pesquisadora. 
O conjunto expositivo é composto de elementos, tais como vitrines que estão colocadas abaixo do modelo do esqueleto da preguiça gigante (FIG. 14), compostas pelos fósseis originais de suas partes como, por exemplo, o crânio (FIG. 15), partes dos ossos dos membros superiores e inferiores e mandíbula.

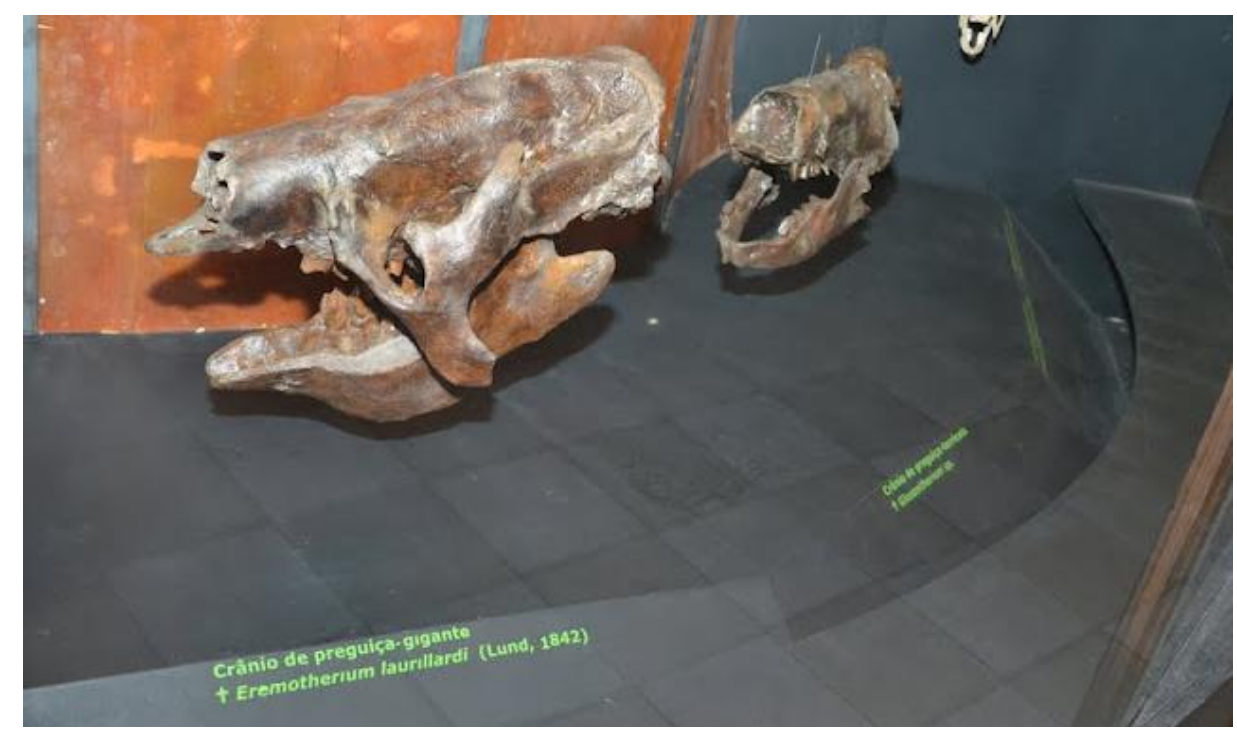

FIGURA 14: Crânio original da preguiça gigante

Fonte: Acervo da pesquisadora.

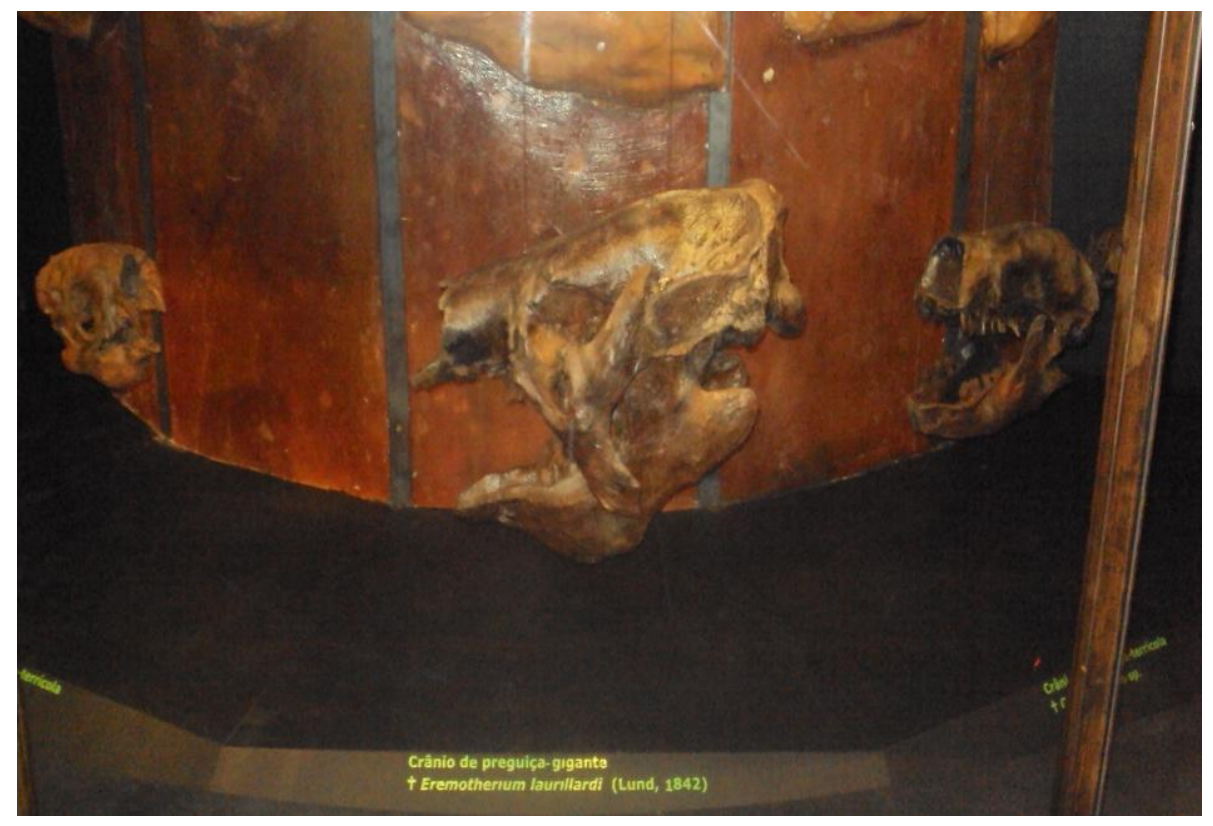

FIGURA 15: Crânio original da preguiça gigante.

Fonte: Acervo da pesquisadora. 
Há, ainda, vitrines com reconstituições de como deveria ser a mão da preguiça gigante, como podemos ver na Figura 16.

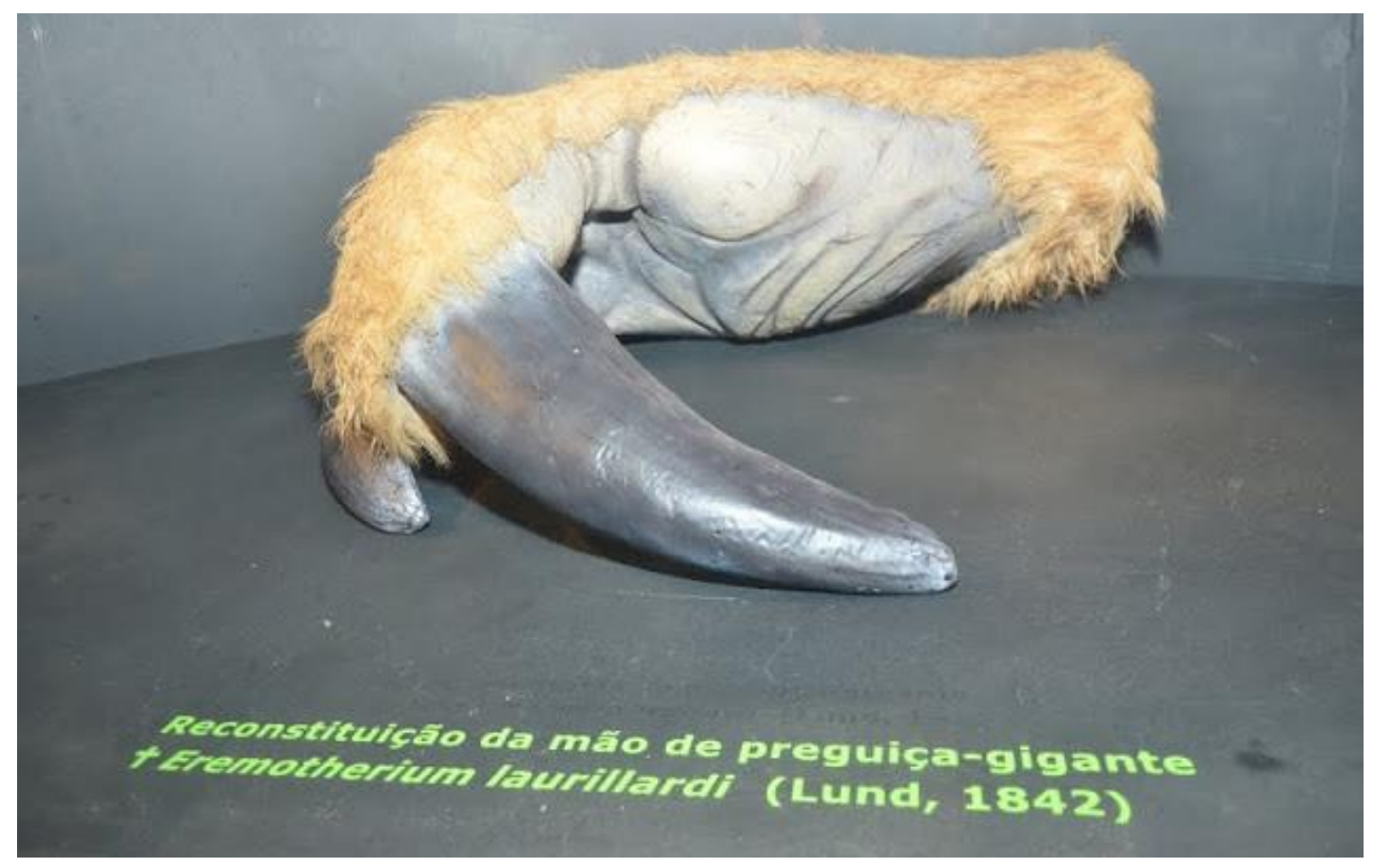

FIGURA 16: Reconstituição da mão da preguiça gigante.

Fonte: Acervo da pesquisadora.

Encontramos, ainda, no conjunto expositivo, reconstituições de outras espécies de preguiças extintas, como por exemplo, a Nothotherium maquinense, vulgarmente chamada de preguiça terrícola (FIG. 17), cujo fóssil foi encontrado por Peter Lund, em 1839, nos arredores da Gruta de Maquiné, Minas Gerais, e que está extinta há mais de 10 mil anos. 


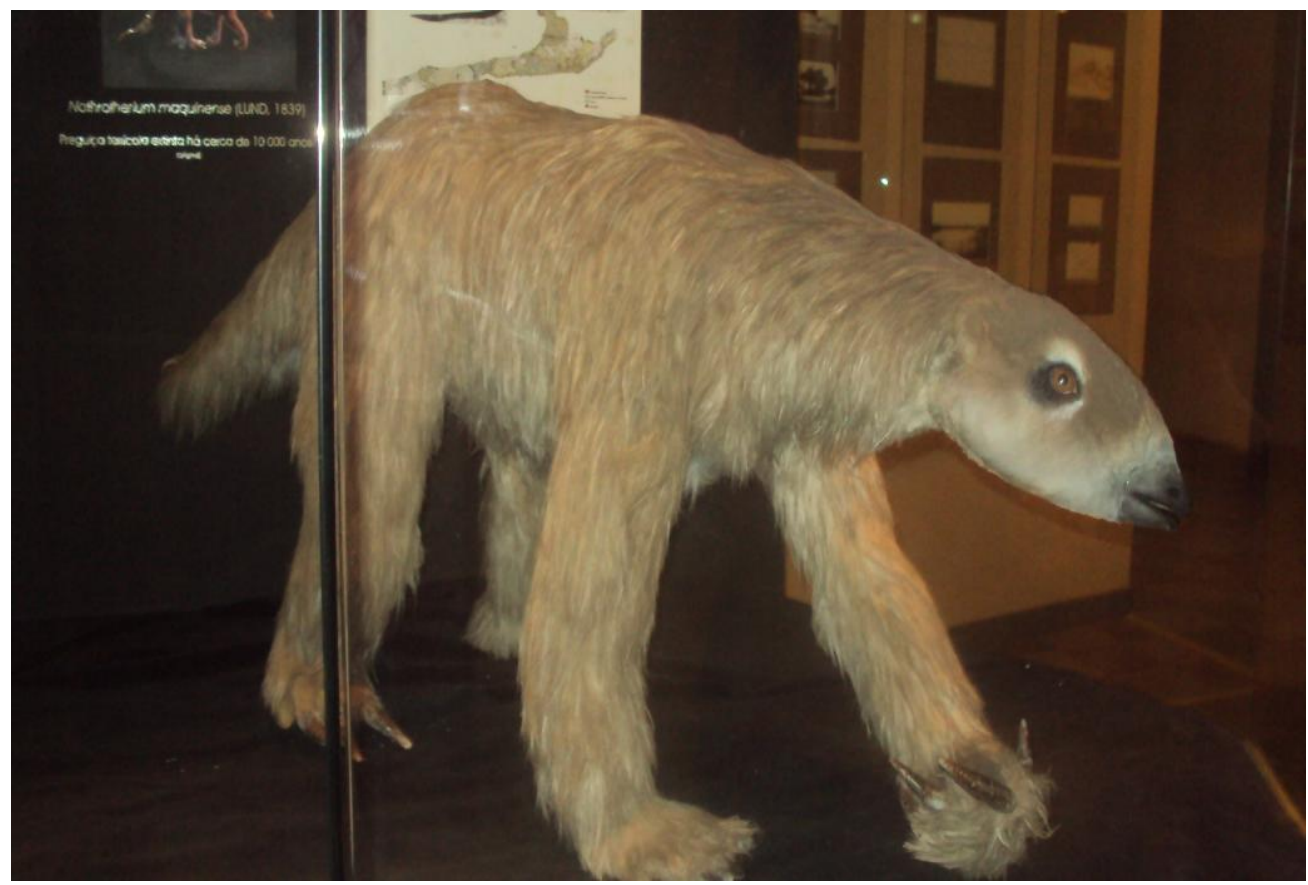

FIGURA 17: Reconstituição da preguiça terrícola, extinta há mais de 10 mil anos. Fonte: Acervo da pesquisadora.

Ao fundo do conjunto expositivo, podemos vislumbrar um grande painel pintado, representativo do ambiente em que viveu a preguiça gigante, o cerrado mineiro. O painel tem aproximadamente seis metros de comprimento e quatro metros de altura (FIG. 18).

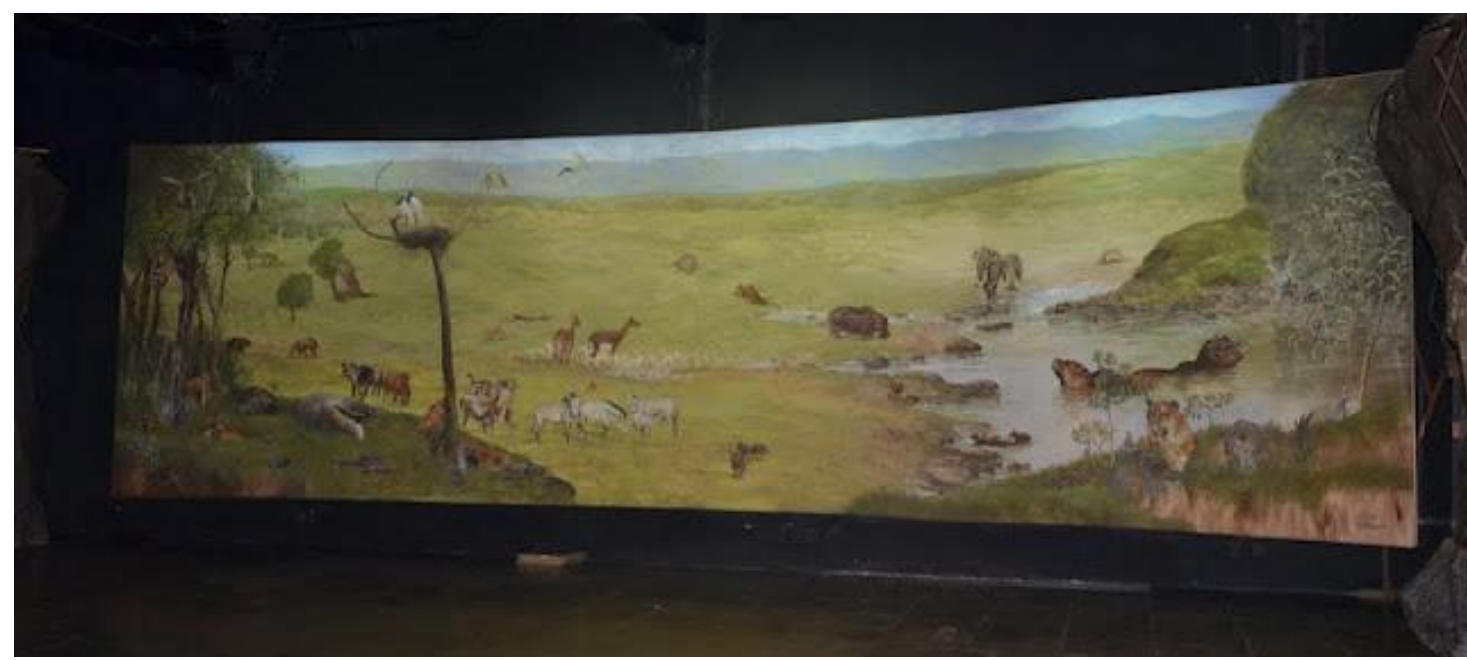

FIGURA 18: Painel pintado que reconstitui o ambiente em que viveu a preguiça gigante.

Fonte: Acervo da pesquisadora. 


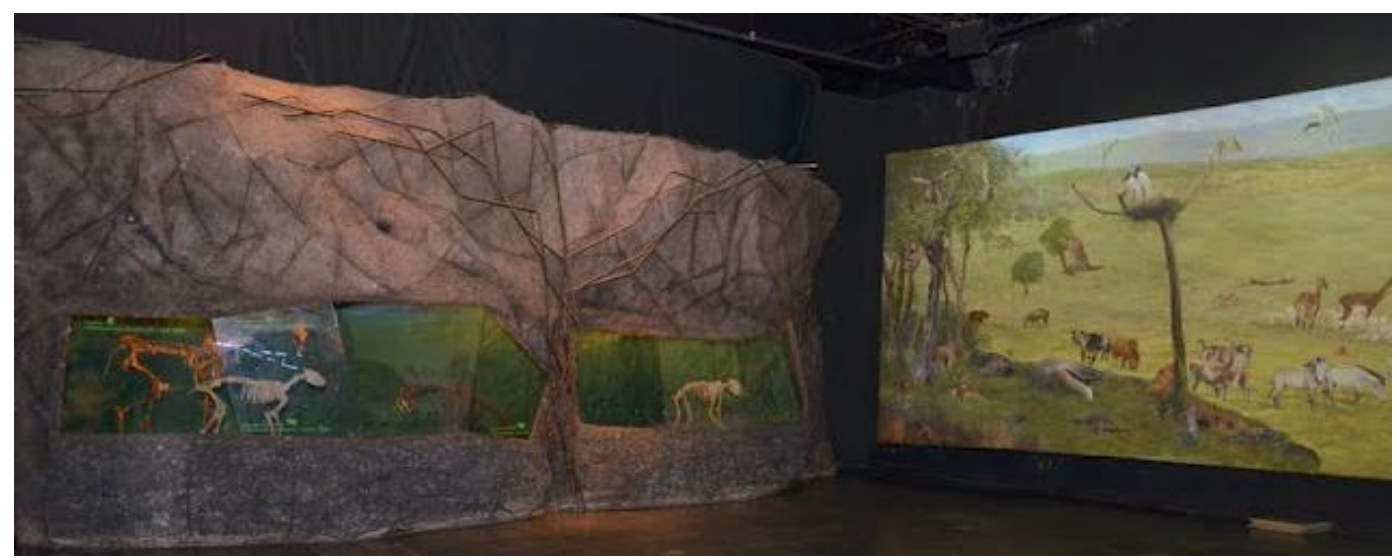

FIGURA 19: Conjunto expositivo.

Fonte: Acervo da pesquisadora.

Os textos, colocados atrás do modelo, elementos do conjunto expositivo, apontam detalhes da vida dos animais no planeta há 11 mil anos, como por exemplo, habitat, ordem pertencente no reino animal, período que viveu na era geológica, dentre outros. Podemos observar esses textos nas figuras 20, 21 e 22.

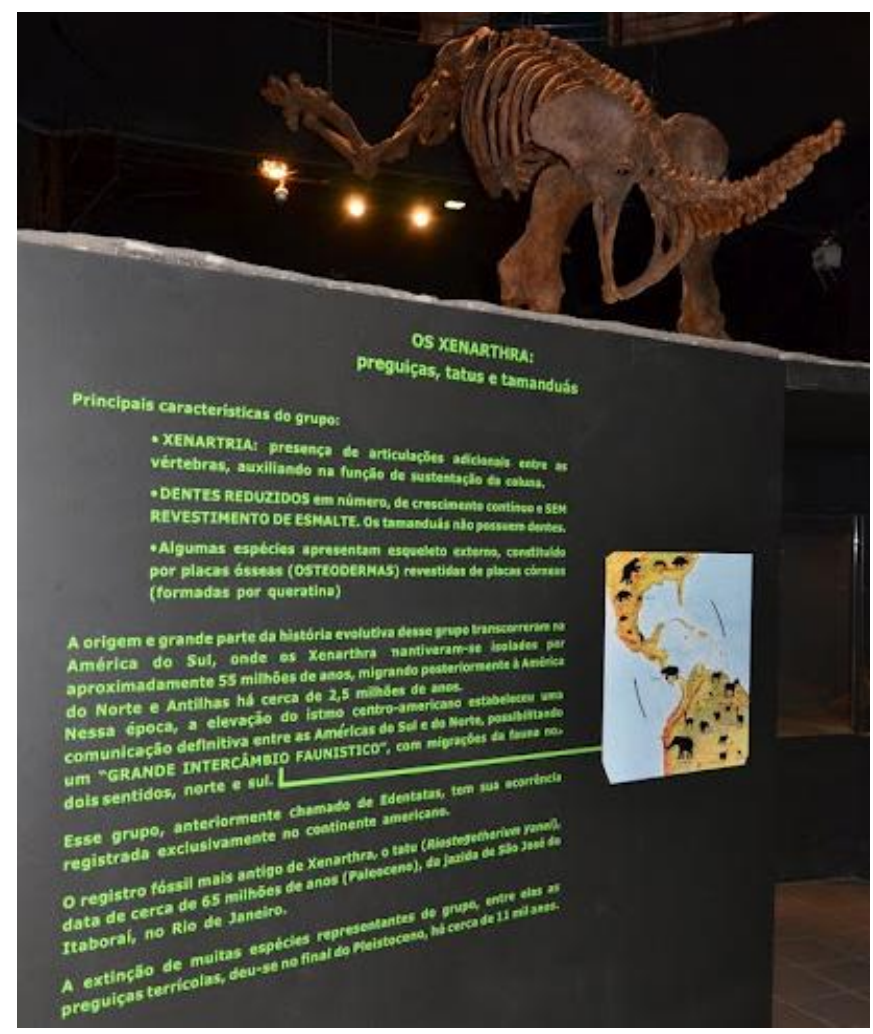

FIGURA 20: Texto pertencente ao conjunto expositivo.

Fonte: Acervo da pesquisadora. 
Ana Maria Senac Figueroa

OS OBJETOS NOS MUSEUS DE CIÊNCIAS:

o papel dos modelos pedagógicos na aprendizagem

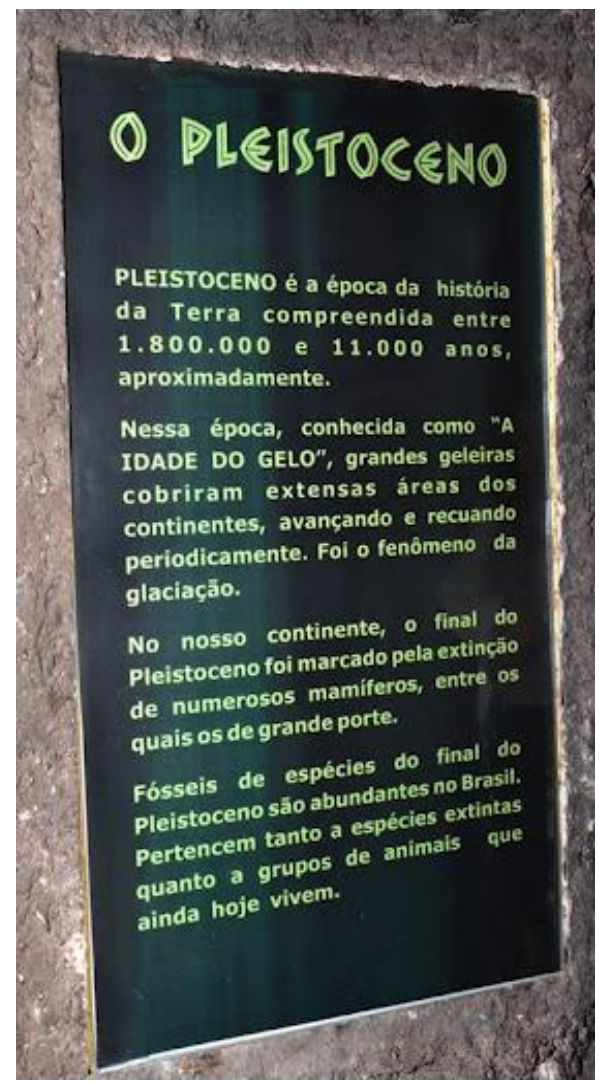

FIGURA 21: Texto pertencente ao conjunto expositivo.

Fonte: Acervo da pesquisadora.

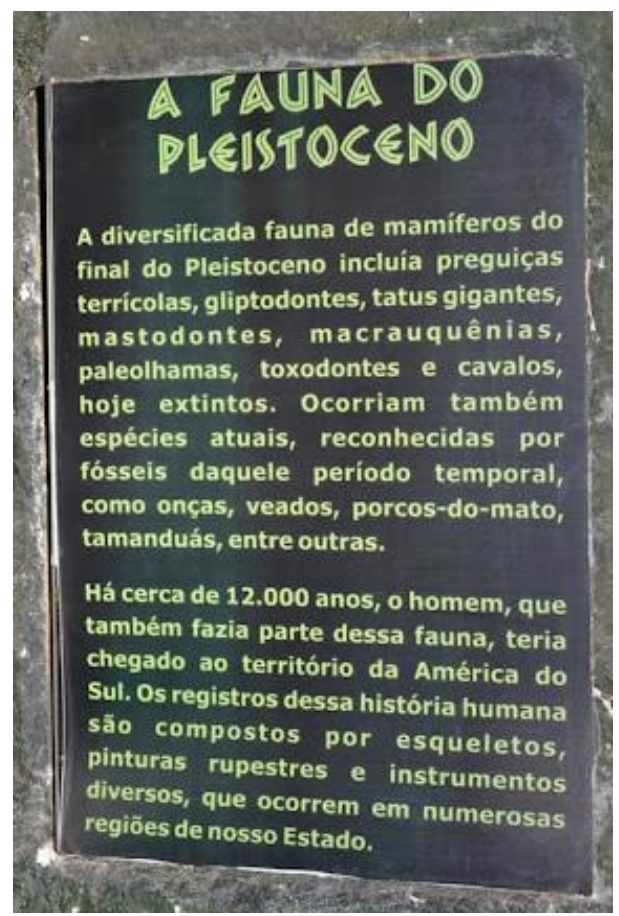

FIGURA 22: Texto pertencente ao conjunto expositivo.

Fonte: Acervo da pesquisadora. 
A partir das descrições das observações dos elementos que compõem o conjunto expositivo e, em especial, do modelo do esqueleto da preguiça gigante, as informações relacionadas às características da espécie como o seu tamanho, tipo de alimentação, locomoção, assim como sobre sua ecologia, são presentes.

$\mathrm{Na}$ observação, também fomos capazes de verificar a composição do conjunto expositivo, que prima ao explicitar a organização dos elementos no espaço e as estratégias museográficas utilizadas, como textos em painéis, etiquetas e objetos em vitrines (FIG. 23).

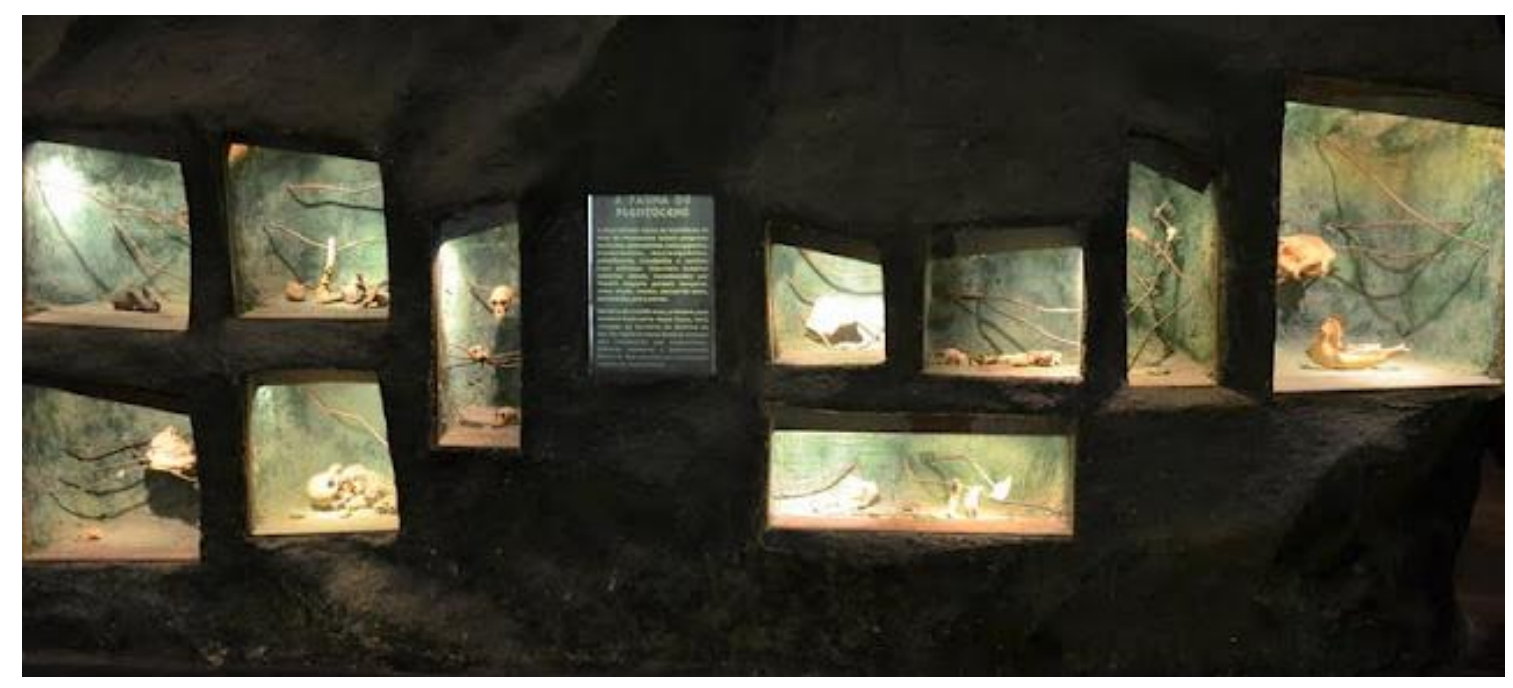

FIGURA 23: Conjunto expositivo.

Fonte: Acervo da pesquisadora.

\subsubsection{O esqueleto da preguiça gigante: $\mathrm{o}$ olhar do museu}

Para que possamos compreender como e por que o modelo foi concebido, ou seja, quais são as intenções do objeto pedagógico, foi necessário obter mais informações acerca do modelo do esqueleto da preguiça gigante, sob o olhar de um dos idealizadores da exposição, em particular, do biólogo responsável, tanto pela elaboração do modelo, quanto pela sua exposição no museu. 
A entrevista (APÊNDICE A) com esse responsável, em particular, foi de fundamental importância para compreendermos os aspectos conceituais e museográficos da exposição como um todo.

Segundo Carlos, o biólogo responsável pela elaboração do modelo, ele está na exposição, não só para transmitir informações pontuais, mas também para indicar que ele é parte de uma fauna de mega mamíferos gigantes, que desapareceram por algum motivo que ainda está sendo estudado. Aponta que,

[...] o papel científico do esqueleto da preguiça gigante na exposição é ser nosso maior animal, a grande estrela da exposição. O modelo foi colocado em pé. É um animal quadrúpede, mas se ergueria numa posição bípede. Mostra a riqueza da nossa fauna e esse animal é muito generalista. Você encontra restos da preguiça do Amazonas até o limite com a Argentina. É um símbolo de um animal que foi muito comum, muito representativo. É também um símbolo do cerrado mineiro.

Assim, para ele, o esqueleto da preguiça gigante representa os conceitos de mudanças climáticas mundiais como a Era Glacial e também a riqueza do cerrado, que já não é mais a mesma dos dias de hoje, pois, no passado, havia uma diversidade muito maior. Constitui, portanto, os conceitos da biologia da conservação e da preservação, ou seja, o que o cerrado perdeu diante de mudanças climáticas.

Para Carlos, quase todo o acervo expositivo do Museu de Ciências Naturais da PUC-Minas é baseado em modelos, que são copiados a partir dos originais, como por exemplo: a preguiça, o tigre dente-de-sabre, toda a fauna de mamíferos. Esses modelos são copiados de material original, que está tombado em arquivos, na coleção de referência. 
A finalidade do museu, segundo ele, é a divulgação da produção científica do Brasil e a criação de questões que passam pela formação do cidadão. $\mathrm{Na}$ concepção do museu estudado, o cidadão brasileiro deve ter orgulho do seu acervo, o que foi feito de história, o resgate da memória. Ele acredita que o museu possui não só a informação científica que quer transmitir, mas também elementos que fazem parte da formação dos cidadãos brasileiros. Assim, ele explica,

[...] que se desenvolva a cultura museal. Ela é muito atrasada ainda, principalmente no Brasil. Então, nós estamos passando por uma fase em que as pessoas começam a visitar museus. Na Europa, isso é algo secular. Na América, já é de praxe. Todo americano pequenininho, o pai já leva ao museu para ver o Tiranossauro rex. Então, estamos formando o início de uma cultura museal.

A coleção paleontológica é a base de partida do Museu de Ciências Naturais da PUC-Minas. Ela foi a primeira coleção de referência do museu. Começou a ser formada no Colégio Loyola, escola privada, de educação básica, localizada em Belo Horizonte, Minas Gerais, com o então professor do colégio, Castor Cartelli. Tinha a finalidade de ensino e de aprendizagem em suas aulas.

Carlos nos informou que, ainda padre, o professor Cartelli, cursou Ciências Biológicas na PUC-Minas. Ele trouxe a coleção de sua propriedade, do Colégio Loyola e, assim, surgiu a possibilidade da criação do museu. Com técnicas ainda rudimentares, a equipe formada por Cartelli, montava os ossos da coleção sobre caixas de areia. Deitavam os ossos originais nessas caixas, porque não tinham como articular os fósseis originais.

Em termos de museologia moderna, hoje, não se usa um fóssil, não se perfura um fóssil para se articular um esqueleto. É uma peça rara de difícil fossilização. Por isso, os modelos são construídos, e o original cabe à pesquisa e à 
Ana Maria Senac Figueroa

OS OBJETOS NOS MUSEUS DE CIÊNCIAS:

o papel dos modelos pedagógicos na aprendizagem

ciência ou ao estudo científico. São os modelos que vão para a exposição. Essa técnica é utilizada para salvaguardar os originais.

Carlos destaca ainda que há uma gama de vantagens em se fazer os modelos a partir dos originais, pois, adquirem mais acervo através de permutas interinstitucionais, como por exemplo, com o Museu Nacional do Rio de Janeiro e o Museu de Taubaté - Professor Alvarenga. Assim explica:

\begin{abstract}
Nós, com uma bateria de moldes de um determinado animal podemos fazer de 3 a 4 réplicas dele. Aí, incorporamos uma à exposição e a outra a gente faz uma troca com outras instituições que nos cedam também as suas réplicas. Originais também. Às vezes, eles nos emprestam o original e a gente trabalha com o original. Às vezes, por questão de propriedade intelectual, com o original que nos vem, nós fazemos o molde, fazemos uma única réplica e devolvemos o original mais o seu molde para a instituição que nos emprestou. Então, essa questão do nosso acervo de réplicas serve tanto como fomento de acervo expositivo, como também um intercâmbio.
\end{abstract}

Outra característica importante com relação ao Museu de Ciências Naturais da PUC-Minas são as parcerias com a Fundação Zoo-Botânica e o Horto Botânico, ambos localizados na cidade de Belo Horizonte, Minas Gerais, porque grande parte do acervo expositivo é constituída por doações dessas instituições. Os esqueletos dos animais que morrem nessas instituições, bem como suas peles, são doados ao Museu da PUC-Minas.

Ainda sobre os objetivos do museu, seu papel na formação do público visitante, segundo Carlos, é dar a conhecer, ou seja,

Nós temos vários setores. Então, a questão do tempo, o resgate do nosso passado que tentamos contextualizar, por exemplo, os nossos dinossauros são todos sul-americanos. As nossas crianças sabem tudo de Tyranossaurus Rex, Velociraptor, mas elas só não sabem que o dinossauro mais antigo foi encontrado no Rio Grande do Sul, 
Ana Maria Senac Figueroa

OS OBJETOS NOS MUSEUS DE CIÊNCIAS:

o papel dos modelos pedagógicos na aprendizagem

recebe o nome do Rio Guaíba, o Guaibassaurus. Então, o ponto de origem, que fascina tanto as crianças, que é a história dos dinossauros, elas não sabem que o tataravô dos dinossauros era brasileiro! Então, a gente trazer a realidade ao menino, abrir o mundo, contextualizando a nível continental e nacional também. Do que é o continente sul americano, do que é a nossa riqueza e do que é o Brasil também. Tentamos levar os visitantes a conhecer, mostrar que também há sítios de dinossauros no triângulo mineiro, em Petrópolis, no Ceará - tem uma riqueza de fósseis do período dos dinossauros, muito grande. Então, não só a criança como o adulto que nos visita, eles se deparam com outra realidade.

Já a finalidade da exposição em que está inserido o modelo do esqueleto da preguiça gigante, objeto de nosso estudo, é mostrar ao público uma visão geral de ambiente e não apenas passar informações pontuais de cada objeto exposto. Para Carlos, a preguiça gigante que está exposta é uma aula da nossa fauna brasileira. Por meio desse modelo espera-se que o público perceba um contexto ecológico de como era o cerrado há 11 mil anos. O público, com o modelo da preguiça gigante e de uma série de tantos outros modelos existentes no museu, pode obter informações específicas, pontuais, sobre a biologia de cada um desses animais, mas a intenção principal é o todo, o ambiente. Para ele,

Isso aí é interessante. Essas pontuações têm um sentido no seu ambiente também. Por exemplo, a preguiça tinha os pés virados para dentro, uma locomoção pedolateral, quer dizer, ela era cambota, ela não apoiava as plantas dos pés, ela pisava pedolateral. Ela era torta. Tem um porquê de ser, então eles vão aprendendo uma série de características. Qual o modelo vivo que teria uma locomoção mais próxima? O tamanduá bandeira, que ainda vive, é um parente dela, da ordem Xenarthra, ordem esta que tem uma importância muito grande. A preguiça é a mais representativa. É uma ordem que tem sua origem no continente sul americano. Esses xenartras são a preguiça gigante, as preguicinhas atuais, tatus e tamanduás. Essa ordem é de fundamental importância biológica para se compreender o cerrado e que esses animais se originaram na América do Sul. Então, aqui, surge uma série de animais totalmente diferentes. Não existe uma preguiça em outro lugar do mundo. Você não vai encontrar um tamanduá na Europa, mesmo que seja fóssil; não vai encontrar uma preguicinha na América do Norte. Assim como os cangurus e os coalas são importantes para a Austrália, as preguiças, os tatus, os tamanduás têm sua importância aqui também. 
Ana Maria Senac Figueroa

OS OBJETOS NOS MUSEUS DE CIÊNCIAS:

o papel dos modelos pedagógicos na aprendizagem

$\mathrm{Na}$ concepção de Carlos, o público consegue vislumbrar, por meio do modelo da preguiça gigante, bem como de todo o conjunto expositivo, que a fauna brasileira do cerrado de hoje é sobrevivente daquele cerrado pretérito, passado, em que se perderam os grandes animais e ficaram os médios e os pequenos.

Através do próprio painel, o público pode retroceder e voltar 11 mil anos, ou seja, que os animais foram pintados para que entendam que eram animais dependentes endêmicos do cerrado. Todos os animais endêmicos desse ambiente desapareceram e para Carlos,

[...] isto é muito curioso. Desapareceram todos os grandes pastadores como a preguiça. Há várias teorias hoje e já se sabe que não é ato humano. Muitos acreditavam que o homem foi chegando ao continente americano e, à medida que ele foi chegando, esses animais foram desaparecendo; mas a gente não tem evidências tão fortes aqui, de como se tem na América do Norte, de caça exaustiva, sob o impacto direto de uma era glacial. Eles caçavam animais maiores por causa da gordura, enquanto que aqui houve um comportamento de caça diferente. Aqui é um clima intertropical, ainda que esteja sofrendo uma influência indireta do último glacial.

A América do Norte - Hemisfério Norte - metade está coberta por uma mina de gelo. O extremo Sul, na América do Sul, também está completamente congelado. Mas o Brasil não deixou de ter suas florestas - elas se reduziram - o cerrado se ampliou. Ainda segundo ele,

[...] você tem toda uma mudança - muito frio - clima seco e frio. O cerrado expande, então você tem esses animais espalhados por todo o território brasileiro. Mais de cerrado, por exemplo, hoje você retira do solo amazônico - uma floresta tropical - do fundo do rio Amazonas você retira animais que não são de floresta amazônica eles são do cerrado. Então, o público em geral, através dos nossos modelos consegue fazer uma associação entre os biomas brasileiros e as mudanças que ocorreram e também uma projeção. Hoje, a perda de diversidade é antrópica, induzida pelo homem. Então, a gente faz essa viagem, através do passado e da perda. Através dos modelos, o menino, o público visitante de maneira geral, consegue perceber um ambiente, que sofreu uma mudança climática muito 
forte. Nós também estamos hoje passando por uma mudança climática muito forte.

O papel dessa exposição, segundo a fala do entrevistado, é tentar interligar essa perda de diversidade pretérita com a futura, através do conhecimento desses animais - a preguiça gigante, por exemplo. Para ele, a característica mais marcante da preguiça gigante é a dependência do ambiente de cerrado, um animal endêmico, pastador, ou seja, que se alimentava de gramíneas, as braquiárias. Ela comia o equivalente ao que come um elefante hoje, por isso precisava de uma área muito grande.

Para Carlos, o modelo do esqueleto da preguiça gigante remete, ainda, à História da Ciência, ou seja, há todo um conjunto de informações que propiciou o seu estudo. Para exemplificar, sabemos que, quando Peter Lund começou a encontrar os ossos da preguiça-gigante, ele não sabia que ela era um animal que pastava. Ele imaginava que ela tinha um comportamento semelhante ao das preguicinhas atuais, que ficam comendo folhas de carnaúba.

Quando Lund achou o fêmur, os ossos da perna e dos braços, segundo Carlos, ele começou a entender o tipo de alimentação das preguiças gigantes, ou seja, que as árvores também deveriam ser gigantes para suportar um animal de tal porte em cima delas. Também pelos dentes em forma de tesoura, Lund foi mudando as concepções que tinha sobre a preguiça gigante. Percebeu que elas não viviam como as atuais preguiças pequenas e, só a partir de estudos com os fósseis, começou a entender como elas faziam uso do seu meio, do espaço onde ela estava inserida. 
Ana Maria Senac Figueroa

OS OBJETOS NOS MUSEUS DE CIÊNCIAS:

o papel dos modelos pedagógicos na aprendizagem

Ainda na concepção de Carlos, o esqueleto da preguiça gigante é um modelo/objeto pedagógico, pois,

[...] é um modelo de um bicho que já existiu, que já viveu, tem um conceito, uma história paleontológica. Ele traz informações nos seus detalhes, na sua forma. Ele traz informações de como poderia ser aquele animal se fosse ressuscitado em ossos, músculos e pele. Ele representa o mais próximo daquele animal vivo. Ele é um modelo, com certeza. Porque, na verdade, ele é muito fiel. A analogia, no meu entender, é criar um modelo que substitua de certa forma, explique a realidade sem vê-la. Que você entenda a realidade com aquele modelo à sua frente. Que ele consiga fazer ver a realidade através de uma representação, de um modelo. E a nossa preguiça, ela serve como modelo, mas não sei se ela serviria para fazer uma analogia, porque ela é a representação física do próprio animal. Não sei se seria uma analogia... Ela é um modelo mais estrutural. Ela, enquanto modelo, leva uma informação direta... essa preguiça viveu no cerrado... eu não sei se encerra outras características. Ela encerra as características do seu ambiente, a noção do seu espaço, encerra um contexto temporal, espacial em que aquele animal existiu. Tem essa utilidade. Além da biologia, do que ela era, da biodinâmica, encerra que espaço era esse, como ela vivia na sua área, com quem interagia e porque não existe mais. Acho que encerra essas características.

Perguntamos ao entrevistado que proximidades e distâncias esse objeto - 0 modelo do esqueleto da preguiça gigante - possui em relação ao original e ele responde:

Tem que se parar para pensar no que é o real. Nossas réplicas são feitas a partir dos originais. Pegamos os fósseis, fazemos os moldes de silicone, abrimos em duas partes, retiramos 0 original $e$ replicamos com resina, poliuretano e fibra de vidro. Então a proximidade do real, digamos assim, é física e mais fiel impossível. É muito próximo. Se eu pegar um osso original da perna do nosso modelo e pegar o original, é como se fosse uma película negativa. Você tirou o filme, você tem a película. O nosso molde de silicone é a película fotográfica - metaforicamente falando aí fazendo uma analogia também. Qualquer detalhe que você vê nessa preguiça, você pega os ossos originais, um espécime que está guardado, tem todas as cicatrizes, todos os acidentes anatômicos, é uma cópia fiel, uma réplica, é um clone do original. Fisicamente mais próximo possível do real, do original. A distância do modelo para o real vai depender muito de como você está trabalhando o conteúdo. São os monitores, a maneira como eles estão expondo essa preguiça. $O$ objeto físico é fiel ao original - mais, impossível. Mas como está 
Ana Maria Senac Figueroa

OS OBJETOS NOS MUSEUS DE CIÊNCIAS:

o papel dos modelos pedagógicos na aprendizagem

sendo trabalhado? Que tipo de informação? A informação que está sendo passada para o público visitante é que pode aproximar ou distanciar aquele objeto da realidade. Então é um conteúdo que é passado, não o visual, a leitura do modelo. O modelo não deixa nada a desejar. Mas, e aí? Que leitura eu faço desse modelo? Que leitura se faz desse modelo? Ver junto ao setor educativo, não é?

De acordo com o entrevistado, as contribuições que esse modelo pode ter na aprendizagem de conceitos científicos para o público são os conceitos de Morfologia e de Ecologia e considera que ele abarca a questão da história dos naturalistas em Minas Gerais. Quando Carlos fala em Peter Lund, diz que está remetendo a fala ao final da segunda metade do século XIX. Ressalta a importância de que, se a História da Ciência for bem trabalhada com os alunos, pode se estabelecer um paralelo por meio do modelo desse animal, a preguiça gigante, ou seja,

[...] por exemplo, se você pular uma parte da história, falar que Darwin, quando esteve no Uruguai, em 1825, achou uma preguiça igual àquela que Lund achou. Dizer também que a preguiça encontrada por Darwin foi montada na Espanha e a maneira como ela foi montada é totalmente errônea em relação a esta aqui. Eu tenho figuras de pranchetas, que ela é feita como se fosse um animal plantídeo, como se fosse um cachorro, toda torta, a coluna é reta, é quase um quadrado. Os membros são retos, a coluna é reta. Então eles não tinham conhecimento. Ela é um gancho para a questão da História da Ciência. Acho que o mais importante é isso. O público, através dessa informação, do patrimônio natural e cultural, isso passa pelo patrimônio cultural brasileiro, tem orgulho de saber que em Minas Gerais existiram tais animais, que um naturalista dinamarquês veio para cá e aquilo o cativou de tal maneira, que ele nunca mais voltou ao seu país e morreu aqui, em solo brasileiro. Então, com isso, se forma o cidadão, com valores, ética.

Para Carlos, o espaço museal, especialmente num museu de Ciências Naturais, tem de ter uma conotação que vai muito além da informação biológica, da informação da história natural. Deve ter um papel social para formar cidadãos. 
Ana Maria Senac Figueroa

OS OBJETOS NOS MUSEUS DE CIÊNCIAS:

o papel dos modelos pedagógicos na aprendizagem

Quando perguntamos a ele se em outra exposição, similar a essa, ele projetaria o modelo do esqueleto da preguiça gigante da mesma forma que se apresenta hoje, respondeu que sim, porém, colocaria uma reconstituição biológica do modelo para atrair mais a atenção do público.

Para ele, as reconstituições biológicas, que mostram os animais na íntegra, não só os esqueletos, aumentam a criatividade, a limitação, e explica:

Nós temos, por exemplo, o elefante no $3^{\circ}$ andar. Quando a maioria do público vê o crânio do elefante, não consegue enxergar 0 elefante, porque ele está vendo o esqueleto, mas está procurando a tromba. A tromba não tem osso, é carnosa. É interessante mesmo explorar a questão dos modelos, por exemplo, eu modelaria a preguiça gigante, em escala natural, esse animal com músculos, com pele, para que a pessoa comparasse o modelo esquelético com o modelo paleoartístico.

Assim, Carlos argumenta que a pessoa pode fazer o modelo mental apenas por meio do modelo do esqueleto, mas o entendimento do que esse modelo representa vai depender do grau de formação e dos conhecimentos prévios de quem o está observando, que leitura está sendo feita. Assim exemplifica:

Uma pessoa que chega aqui e fala: Ah, é uma preguiça, ah, tá! Então ela vai imaginar uma preguiça lenta, em cima de uma árvore? Essas preguiças eram pastadoras, se deslocavam muito, talvez tivessem uma movimentação muito maior do que uma preguiça de hoje... Então, quer dizer, ela é um modelo que vai transmitir uma série de informações, mas as informações vão ser traduzidas de maneiras diferentes, de acordo com a realidade social e educacional de cada público.

Carlos acredita que as pessoas têm limitações porque a sociedade é plural, é diversa. Por isso, acha difícil ter um modelo universal pra se explicar um determinado conhecimento. Ele sabe que existem modelos que são clássicos, mas acha difícil que exista um modelo totalmente pronto, completo. Para ele, a maneira 
que apresentamos o modelo tem de estar voltada para a realidade cultural do público, pois, caso contrário, não conseguimos alcançar nosso objetivo, passar o conteúdo através daquele modelo.

Ainda para Carlos, temos de conhecer a realidade do público que está visitando o museu e, particularmente, aquele modelo específico, para não termos ideias pré-concebidas, ou até mesmo já formadas sobre esse público. A comunidade precisa ser alcançada, para que possa compreender o conceito que o modelo encerra.

O modelo do esqueleto da preguiça gigante, para ele, é um modelo que foi feito para ensinar, é um modelo pedagógico, é um modelo para divulgar ciência, para divulgar sobre a fauna pretérita brasileira, sobre o cerrado. A respeito disso, Carlos diz que, "[...] o grande segredo aí é como trabalhar com esse modelo pedagógico. Como ele está sendo utilizado... mas, que ele é um objeto/modelo pedagógico, sem sombra de dúvidas, ele é".

A partir dos dados obtidos acerca do objeto pedagógico e do conjunto expositivo, sob o olhar do museu, novamente podem ser destacados entre os objetivos da exposição, aqueles que se referem às características da espécie da preguiça gigante. Destacamos seu tamanho, locomoção, ordem, bem como aspectos de seu contexto biológico/ecológico, como o tempo geológico em que viveu, o habitat, a sobrevivência da espécie. Ainda ressaltamos aspectos do ambiente museológico, quando se destaca a posição em que está exposta, ou seja, posição bípede, própria para se alimentar das folhas das copas das árvores, posição de altivez para um maior impacto do visitante. 
Dessa forma, articularemos os dados desse conjunto de intenções, sob o nosso olhar e sob o olhar do museu, com as interações dos jovens, destacadas a seguir, e com base nos eixos de análise, ou seja, os eixos que tratam das dimensões da aprendizagem - conceitual e processual.

\subsection{AS INTERAÇÕES DOS JOVENS COM O MODELO DO ESQUELETO DA PREGUIÇA GIGANTE}

A pesquisa com os jovens conta com quatro etapas, que se desenvolveram uma a uma, sempre com os jovens em grupo, com a finalidade de observarmos as interações deles com o objeto pedagógico e com todo o conjunto expositivo.

Os cinco jovens, Elisa, João, Marina, Rita e Anita, sujeitos da pesquisa, foram convidados a participar da pesquisa e aceitaram prontamente o convite. Todos têm 17 anos de idade e estão cursando o $3^{\circ}$ ano do ensino médio, em escolas privadas, localizadas na cidade de Belo Horizonte, Minas Gerais.

\subsubsection{Primeira etapa: antes da visita}

Perguntamos aos jovens se já haviam visitado um museu de ciências naturais. Três deles, Elisa, João e Marina, já haviam visitado anteriormente algum museu de ciências, em visitas agendadas com a escola.

Elisa já havia visitado o Museu de Ciências Morfológicas da Universidade Federal de Minas Gerais, o Museu de História Natural da UFMG e o Museu de Ciências Naturais da PUC-Minas. 
Ana Maria Senac Figueroa

OS OBJETOS NOS MUSEUS DE CIÊNCIAS:

o papel dos modelos pedagógicos na aprendizagem

João visitara o Museu de História Natural da UFMG e o Museu de Ciências Naturais da PUC-Minas.

Marina havia visitado o Museu de Ciências Morfológicas da Universidade Federal de Minas Gerais.

Rita e Anita ainda não conheciam nenhum museu de ciências.

Sobre o que os jovens mais gostaram nos museu de ciências visitados, agrupamos as respostas.

Elisa gostou dos esqueletos dos dinossauros e completou

Elisa: [...] gostei de tudo lá nos museus.

João gostou dos esqueletos dos dinossauros e completou

João: [...] gostei de ver os esqueletos dos animais que conheci no zoológico vivo e, depois de mortos, foram doados ao museu.

Marina gostou de ver os órgãos conservados no formol, pulmões dos fumantes e completa

Marina: [...] adorei ir ao Museu de Morfologia da UFMG.

Rita: Não visitou um museu de ciências antes.

Anita: Não visitou um museu de ciências antes.

Em seguida, perguntamos aos jovens o que eles aprenderam nos museus visitados, e para Elisa, 
No Museu da PUC-Minas aprendi muito sobre os animais de outras eras. Que o Peter Lund encontrou fósseis na região de Lagoa Santa, importantes para descobertas da vida em outras épocas. Aprendi também que eles reconstroem os esqueletos com pedaços verdadeiros e os que não encontram, eles montam com resinas e poliuretano. No museu de morfologia da UFMG... ah! faz tempo que eu fui. Lembro-me dos órgãos do corpo humano guardados em vidro, dos pulmões dos fumantes, cérebro, olho e coisas assim.

João disse que aprendeu vendo os esqueletos, como os corpos eram sustentados e sua estrutura esquelética.

Marina argumentou que não lembrava mais...

Faz muito tempo. Eu me lembro dos pulmões dos fumantes e aprendi que não se deve fumar, devido aos danos causados pelo cigarro à saúde. Lembro-me dos pulmões num vidro e lembro também do corpo humano com olhos de vidro. É pra preservar? Sei lá...

Rita e Anita ainda não conheciam nenhum museu de ciências.

Para a questão 06 da entrevista (APÊNDICE B): Que objetos da(s) exposição(s) que você já visitou, chamaram mais a sua atenção? Cite pelo menos três objetos. Explique por que eles chamaram a sua atenção.

Para Elisa, o objeto que mais chamou sua atenção foi o esqueleto da preguiça gigante, por seu tamanho.

Já para João, todos os objetos chamaram a sua atenção. Disse que havia gostado de tudo no museu da PUC-Minas e que não se lembrava do que mais havia gostado no outro museu visitado.

Marina apontou para essa questão, o corpo humano de verdade, com o olho de vidro de mentira, inferindo: 
Ana Maria Senac Figueroa

OS OBJETOS NOS MUSEUS DE CIÊNCIAS:

o papel dos modelos pedagógicos na aprendizagem

Aqui tá pedindo prá citar três objetos. O corpo humano não é um objeto. O olho de vidro é. O pulmão de fumante num vidro e o cérebro também no vidro, cérebro de verdade.

Para os jovens Marina, Rita e Anita, que ainda não haviam visitado o Museu de Ciências Naturais da PUC-Minas, perguntamos o que esperavam encontrar no museu. Assim, disseram que poderiam encontrar animais, esqueletos, corpo humano e bichos empalhados.

Aos jovens que já conheciam o Museu de Ciências Naturais da PUC-Minas, perguntamos que objeto Ihes chamou mais a atenção e por quê. As respostas estão ordenadas em itens a seguir:

Elisa: Conheço. O que mais me chamou a atenção foi o tamanho da preguiça gigante, bem como, uma vitrine com os Poríferos, que achei legal porque havia estudado o ano passado. É bom quando você pode ver as coisas que você estudou na aula e nos livros, assim de verdade.

João: Sim, conheço. O que mais me chamou a atenção foi o esqueleto da baleia. Só não gostei das emendas que eles fizeram no esqueleto. Foram mal feitas. Dava pra perceber direitinho o que era mesmo o osso de verdade e o que era emenda. Mas, mesmo assim, achei legal. Gostei também da parede, acho que é pintada, explicando como era o cerrado 11 mil anos atrás. Você vê os esqueletos e depois vê um painel dos animais como eram antigamente.

Ainda, para os jovens que já conheciam museus de ciências foi perguntado se eles consideram que todos os objetos existentes no museu da PUC-MINAS são de verdade e que justificassem as respostas. Estas também estão ordenadas em itens a seguir:

Elisa: Não. Acho que os esqueletos e os animais são feitos lá no museu. A zebra, não tem como aqueles esqueletos serem todos de 
verdade... eles montam. As conchas, na exposição do mar, até que eu acho que são de verdade. Eles pegam no mar mesmo... É isso.

João: Acho que não. A baleia mesmo, de que eu falei, é uma parte de verdade e a outra parece de massa branca. Quando eu fui lá ao museu da outra vez, entrei atrás do painel e vi uns pedaços de coisas que parece que eles estavam fazendo. Assim, parte dos bichos... aí, eu saquei que eram eles que montavam, que faziam as coisas do museu. Sério.

Marina: Acho que não. O corpo humano mesmo o que está lá na UFMG, o cadáver tem olho de vidro, um olho azul, de vidro parece. Os órgãos que estão no formol são de verdade e há também uns negócios de gesso, tipo células, tecidos. Esses são de gesso e não são de verdade.

Rita: Acho que não. Não sei mesmo. Só indo lá pra ver... hahaha.

Anita: Acho que não. Em museu de arte, assim de coisa velhas, eu acho que é tudo de verdade. Museu de ciências...hummm...não sei...pode até ser, né?

E, sobre a importância de visitar um museu de ciências naturais, como o museu da PUC-Minas, todos responderam que a importância era a de aprender sobre as coisas, ou seja, coisas que eles nunca viram pessoalmente, que não há mais na natureza, aprender sobre os bichos, coisas da ciência e da biologia.

A atividade de construção do modelo da preguiça gigante (APÊNDICE C), que ocorreu ainda nessa etapa, os jovens foram convidados a modelar o esqueleto da preguiça gigante com massinha de modelar, antes da interação com o mesmo no museu. A etapa foi executada logo após a entrevista. Ela teve por objetivo principal compreender quais eram os conhecimentos prévios dos jovens sobre o esqueleto da preguiça gigante. 
Antes de dar início à atividade de modelagem (APÊNDICE C), perguntamos aos jovens se já haviam visto uma fotografia ou um desenho de como havia sido a preguiça gigante há 11 mil anos. Apenas os jovens Elisa e João já haviam visto o objeto pedagógico no museu e no painel exposto do museu escolhido para nossa pesquisa. Já os jovens Marina, Rita e Anita não conheciam o modelo do esqueleto da preguiça gigante.

Marina, por sua vez, refletiu e disse que já havia visto uma preguiça, mas que não sabia se ela era gigante. Achava que não. Disse também que a imaginava na cor cinza, toda lenta, com três dedinhos e unhas bem grandes. Imaginava, ainda, que a preguiça possuía um focinho bem pequeno e uma carinha pequena também. Inferiu que a preguiça gigante deveria ser um animal muito perigoso.

Rita comentou que já havia assistido ao filme A Era do Gelo, mas disse que a preguiça do filme não era gigante. Inferiu que ela era preguiçosa, grande e que não existe mais. Ainda formulou uma questão e a respondeu:

Sabe o que aconteceu com ela? Houve a seleção natural, a de Darwin, onde os bichos tinham que se adaptar ao meio. A partir dessa preguiça gigante, é que se deu a origem da preguicinha normal, que nem aquele lance do pescoço da girafa.

Anita não fez nenhum tipo de inferência ou comentário a respeito da preguiça gigante.

A seguir, perguntamos o que os jovens conheciam sobre a importância desse animal para o planeta, há 11 mil anos, e o como percebiam o ambiente em que ele viveu. Apenas Rita acredita que a preguiça gigante tenha tido um importante papel para o planeta 11 mil anos atrás, ou seja, que ela não existiu à toa, sem um 
papel. Rita ainda acrescenta que ela fazia parte de uma cadeia alimentar e que desapareceu por causa de mudanças climáticas.

Com relação ao ambiente em que a preguiça gigante viveu, Marina enfatiza que era um local com muitas árvores, com muitos frutos. Rita concorda com Marina. Os demais jovens não souberam responder.

Após as considerações acima citadas, os jovens deram início à atividade de construção do modelo do esqueleto da preguiça gigante.

A atividade fluiu livremente, com os alunos conversando entre si, principalmente acerca de que elementos estruturais deveriam colocar no modelo. Surgiram dúvidas e questões, tais como: Ela tinha rabo? Será que ela tinha unhas, garras? Posso colocá-la na árvore? Será que eu posso colocá-la comendo folhas das árvores? Ela tinha três garras? O que eu faço? Eu não gosto de trabalhar com massinha.

As perguntas não foram respondidas no momento da construção do modelo, para que não houvesse interferências nas concepções iniciais do conhecimento dos jovens sobre a preguiça gigante.

Ao final da atividade, já com os modelos de massinha construídos, ficaram eufóricos, tanto para fotografar os respectivos modelos, quanto para sairmos em visita ao museu. 
Ana Maria Senac Figueroa

OS OBJETOS NOS MUSEUS DE CIÊNCIAS:

o papel dos modelos pedagógicos na aprendizagem

\subsubsection{Os Modelos Iniciais dos Jovens}

\section{Modelo inicial de Elisa}

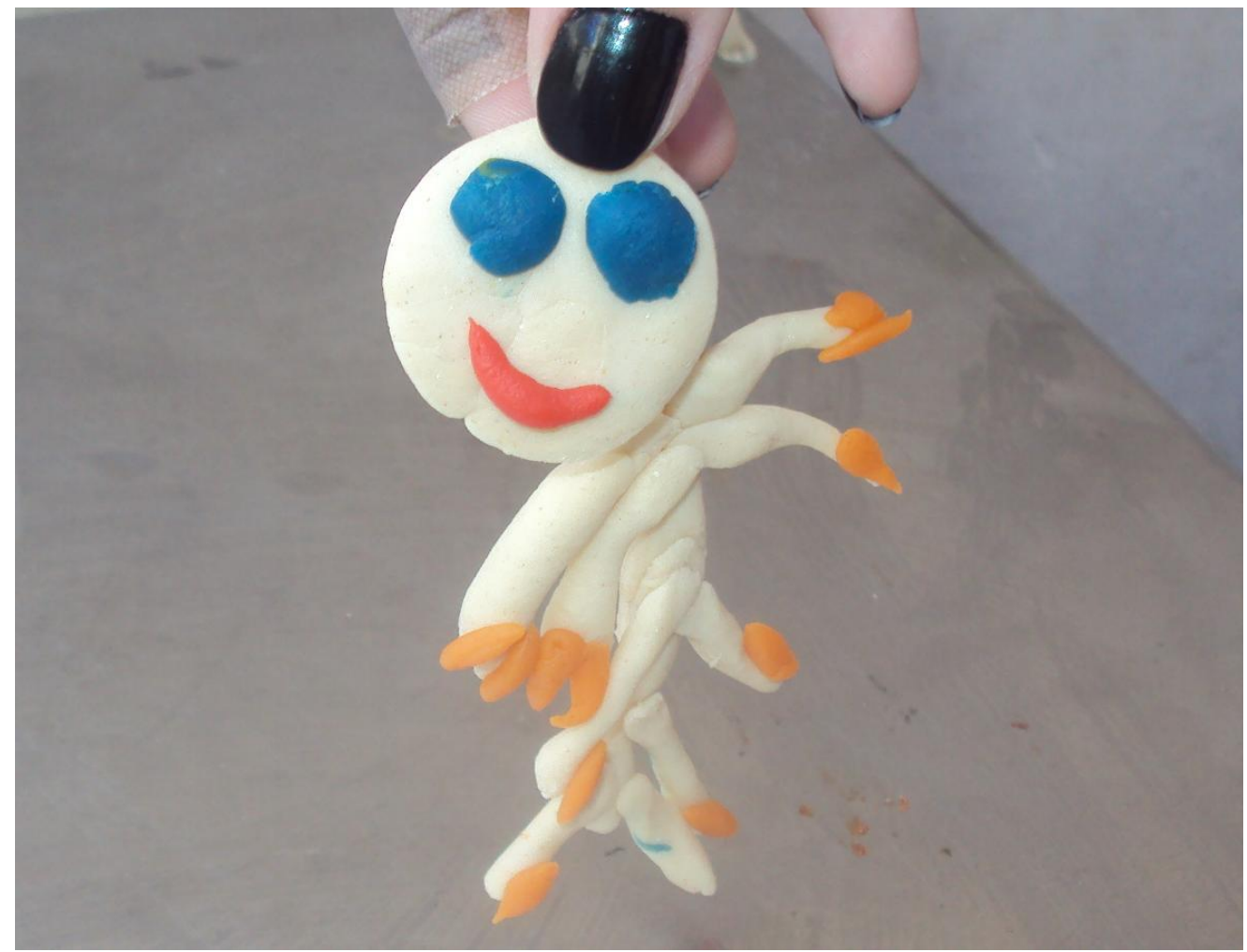

FIGURA 24: Modelo inicial de Elisa.

Fonte: Acervo da pesquisadora.

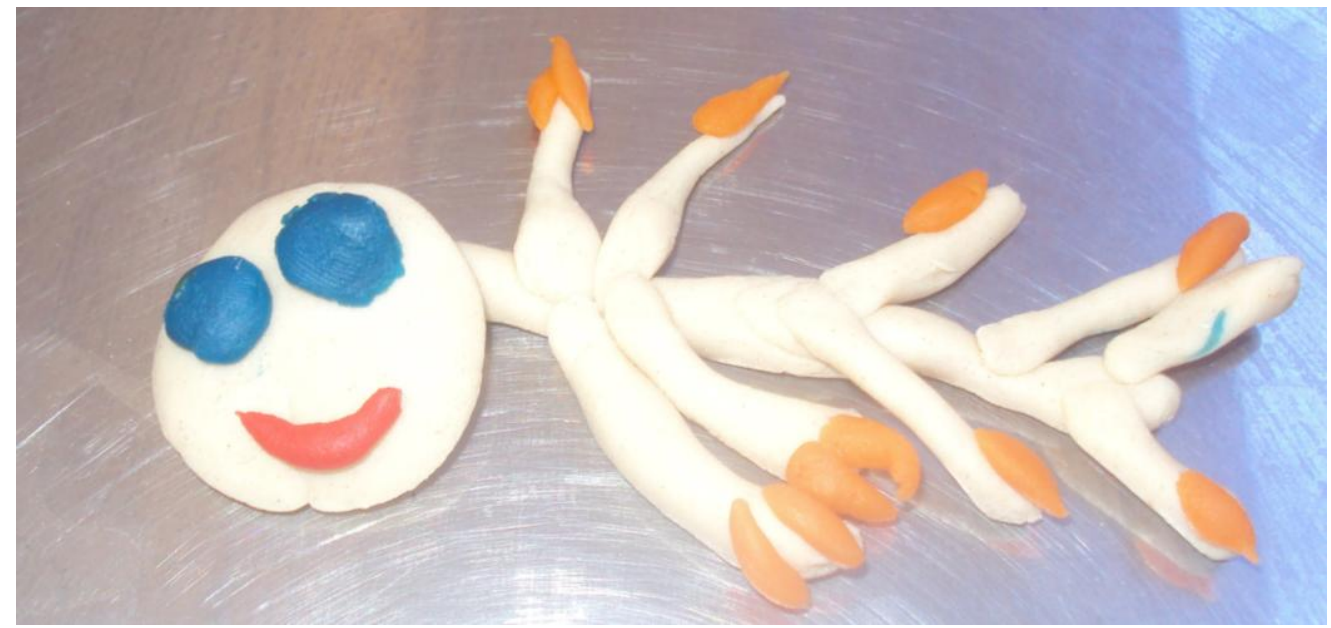

FIGURA 25: Modelo inicial de Elisa.

Fonte: Acervo da pesquisadora. 
O modelo inicial, que Elisa elaborou, contou com uma coluna vertebral e muitos membros. Em cada membro, a jovem colocou duas garras e, diferentemente de um esqueleto, o modelo conta com cabeça, boca e olhos bem definidos.

\section{Modelo inicial de João}

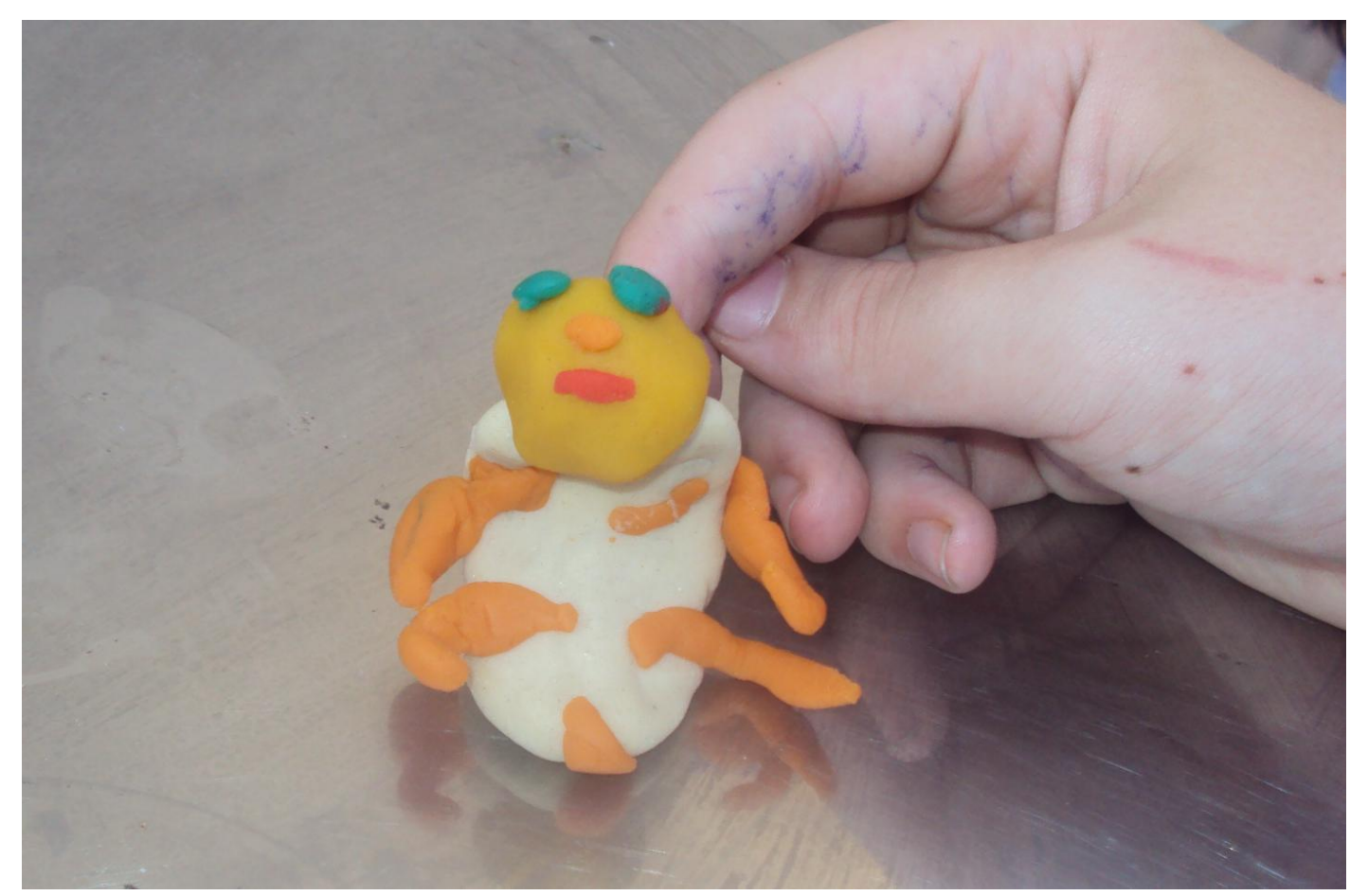

FIGURA 26: Modelo inicial de João.

Fonte: Acervo da pesquisadora.

O modelo inicial, que João elaborou, contou com quatro membros sem as garras e corpo bem definido. A cabeça continha olhos, boca e nariz bem definidos. Simulou uma posição bípede do animal e acrescentou uma pequena cauda. 
Ana Maria Senac Figueroa

OS OBJETOS NOS MUSEUS DE CIÊNCIAS:

o papel dos modelos pedagógicos na aprendizagem

\section{Modelo inicial de Marina}

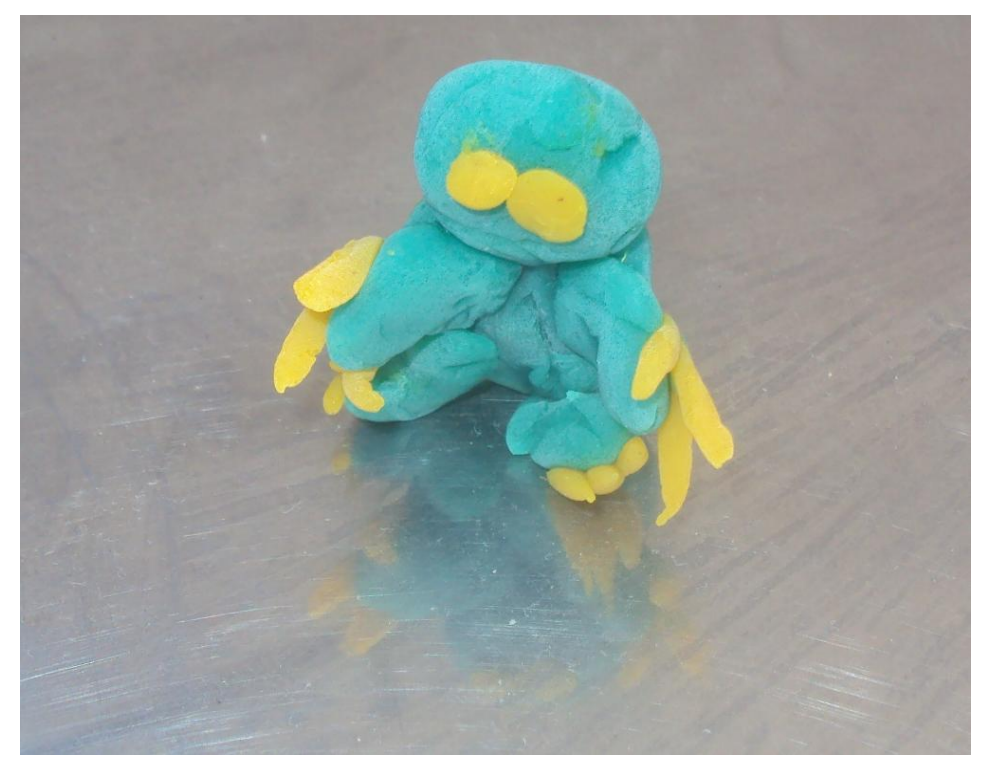

FIGURA 27: Modelo inicial de Marina.

Fonte: Acervo da pesquisadora

O modelo inicial de Marina continha quatro patas com três garras em cada uma, corpo e olhos bem definidos e apresentou o modelo numa posição bípede.

\section{Modelo inicial de Rita}
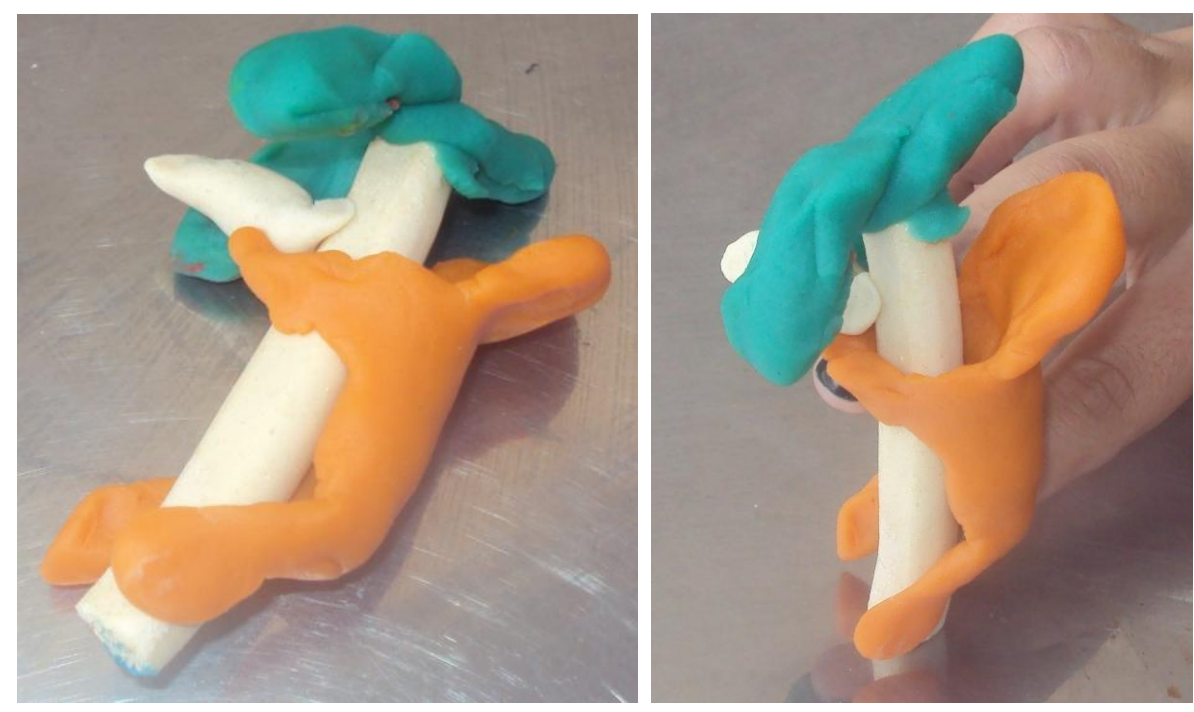

FIGURA 28: Modelo inicial de Rita.

Fonte: Acervo da pesquisadora. 
O modelo inicial de Rita apresentou quatro patas sem as garras, corpo definido e colocou o animal abraçado a uma árvore. Colocou-o em uma posição bípede e se alimentando de folhas.

\section{Modelo inicial de Anita}

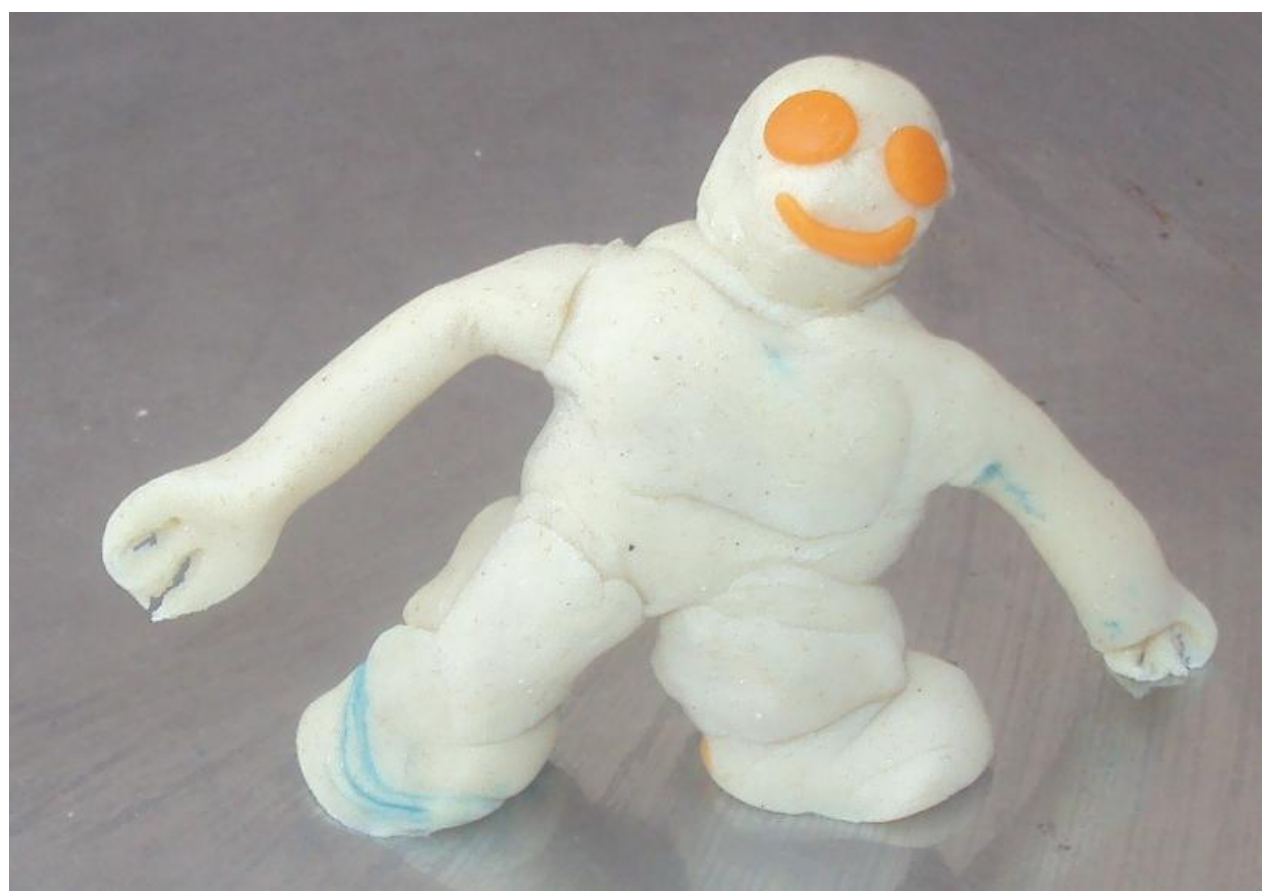

FIGURA 29: Modelo inicial de Anita.

Fonte: Acervo da pesquisadora.

O modelo inicial que Anita elaborou continha quatro patas com três garras apenas nos membros superiores. A jovem definiu bem o corpo, os olhos e a boca e colocou o modelo em uma posição bípede.

Logo após a confecção dos modelos em massinha, saímos em visita ao museu. 


\subsubsection{Segunda etapa: durante a visita}

A segunda etapa da pesquisa é a visita ao Museu de Ciências Naturais da PUC-Minas. Nessa etapa, os jovens foram encaminhados diretamente para 0 conjunto expositivo, onde está colocado o modelo do esqueleto da preguiça gigante. Orientamos a visita no sentido de fazermos com que eles observassem atentamente o modelo pedagógico, objeto de nosso estudo.

A primeira reação dos jovens frente ao modelo foi de espanto com o tamanho e a altivez que o modelo do esqueleto da preguiça gigante imprime. As primeiras falas se referiram aos elementos estruturais que eles haviam colocado no modelo de massinha, elaborados por eles inicialmente.

Marina comenta que não sabia que a preguiça gigante tinha rabo. Rita percebeu que não tinha feito o esqueleto do animal como havia sido orientada, e disse:

Ai...eu não fiz os ossos, eu fiz a preguiça de verdade!

Durante a observação do modelo pelos jovens, utilizamos placas de papel sulfite, com perguntas (APÊNDICE D) que julgamos necessárias naquele momento da visita, como forma de instigar a interação dos jovens com o objeto pedagógico e também as interações entre eles, naquele momento.

Sobre o que os jovens conseguiam ver a respeito da originalidade do esqueleto, os cinco foram unânimes em responder que era de "verdade", ou seja, que o objeto pedagógico era o fóssil original dos ossos da preguiça gigante, que foi encontrado por Lund, segundo a legenda que está colocada abaixo do modelo. 
Sobre o que eles estavam aprendendo em frente ao esqueleto da preguiça gigante, Elisa relatou que ela deu origem às preguiças de hoje. Rita entendeu que pelo tamanho do esqueleto, a preguiça gigante teve um importante papel 11 mil anos atrás, porém, não soube explicar que papel teria sido esse.

Os jovens foram também unânimes em dizer que o modelo da preguiça gigante foi um animal bípede, questão que foi levantada por nós, pois é nesta posição que está colocado na exposição. Mas, após uma breve discussão entre eles, chegaram à conclusão de que a preguiça era quadrúpede e que só se colocava numa posição bípede para apanhar as folhas das árvores de que se alimentava e que, para se locomover, a preguiça era quadrúpede. Essa conclusão foi dada antes de observarem o conjunto expositivo, que está colocado atrás do modelo do esqueleto da preguiça gigante, que dá essa "pista" aos visitantes.

Os jovens continuaram a visita ao conjunto expositivo, que está colocado logo atrás do modelo do esqueleto da preguiça gigante, ou seja, leram os textos e observaram as vitrines com os outros elementos que o compõem e, com ares de estarem pensando acerca do objeto pedagógico, continuaram a visita.

A seguir, após levantarmos a questão na placa de papel (APÊNDICE D), Elisa e Rita acrescentaram que, se o modelo do esqueleto da preguiça gigante estivesse em exposto em outro lugar, ele teria os mesmos propósitos, pois, a função dele é a de mostrar que um dia a preguiça gigante existiu. Rita, ainda completou,

Se a preguiça gigante estivesse na Praça Sete, as pessoas iriam ficar pensando sobre ela, assim como nós estamos pensando...não iam? 
Quanto ao comportamento dos jovens frente ao objeto pedagógico, observamos que os mesmos se mostraram um pouco inquietos, com a demora da observação, bem como, com os questionamentos. Estavam ansiosos para conhecer todo o museu.

A leitura dos textos pelos jovens se mostrou frutífera, pois eles a confrontaram com informações prévias e confirmaram o que haviam dito sobre o objeto pedagógico, ou seja, tipo de alimentação, locomoção e ambiente biológico em que viveu a preguiça gigante.

Ao se depararem com um modelo de outra espécie de preguiça, agarrada em uma árvore, no momento de se alimentar, Rita percebeu que não havia modelado o esqueleto da preguiça gigante, mas sim, esse modelo de outra espécie - a preguiça terrícola. Ela percebeu o equívoco imediatamente e ressaltou que o que tinha na mente era o modelo dessa espécie e não o da preguiça gigante, porque já o havia visto em algum lugar.

No painel de grandes proporções, que retrata o ambiente do cerrado há 11 mil anos, os jovens puderam visualizar a preguiça gigante se alimentando de folhas de grandes árvores, bem como os animais que compunham aquele ambiente, naquela época. Ficaram impressionados e questionaram como os pesquisadores podem retratar um cenário de 11 mil anos, se não conheceram o ambiente. Inferiram, nesse momento da visita, que as pesquisas são úteis para reconstruírem esses ambientes e que é exatamente essa a função dos fósseis, mesmo que reconstruídos dos originais. 
A visita a todo o conjunto expositivo, onde está exposto o modelo do esqueleto da preguiça gigante, foi de grande interesse para os jovens, visto que pudemos observar que liam todos os textos e conversavam sobre o tema. Comparavam com os modelos de massinha de modelar que haviam construído anteriormente e, apontavam para estruturas de outros objetos pertencentes ao conjunto expositivo e comentavam sobre o ambiente no grande painel.

Após a visita ao conjunto expositivo onde está inserido o objeto pedagógico de nosso estudo, demos sequência à visita a todo o museu, pois os jovens se mostraram interessados em conhecer, discutir, questionar e também fotografar tudo o que Ihes chamava a atenção.

\subsubsection{Terceira etapa: depois da visita}

A terceira e última etapa da coleta de dados com os jovens, que ocorreu logo após a visita ao museu, contou com a atividade de reelaboração do modelo do esqueleto da preguiça gigante, com massinha de modelar (APÊNDICE E), ou seja, foi solicitado a eles que construíssem outro modelo, após terem conhecido o objeto pedagógico no museu.

De acordo com as questões contidas na referida atividade, enfatizaram que gostaram muito da visita e que puderam ver "ao vivo", conteúdos que haviam visto na escola, como os poríferos, equinodermos, dentre outros, expostos no museu.

Marina, Rita e Anita argumentaram que não imaginavam que o modelo do esqueleto da preguiça gigante era do tamanho como está apresentado no museu. Marina disse que pensava que a preguiça gigante fosse menor. 
Rita enfatizou que descobriu que quase tudo o que viu no museu é "falso". Só os animais do mar ela acreditou serem os exemplares extraídos do ambiente natural e levados para o museu.

Marina apresentou, enquanto construía o seu modelo de massinha de modelar, os conceitos que ficaram claros para ela acerca do objeto pedagógico, quais sejam: que a preguiça gigante era da ordem Xenarthra, que era quadrúpede e que viveu no cerrado há 11 mil anos. Afirmou ainda que a preguiça gigante foi um animal herbívoro, e argumentou que, se o fóssil original estivesse no lugar do modelo elaborado pelo museu, ela o entenderia da mesma forma.

Anita, uma jovem muito tímida, mostrou não saber articular bem as idéias e não soube dizer com clareza o que observou no museu. Generalizou a sua resposta dizendo que havia gostado da visita e, ainda, que gostou muito de ver a baleia.

João disse que não conhece outros meios para se compreender acerca de vários conteúdos da ciência, senão por meio da observação dos objetos em museu. Falou que, apenas observando o esqueleto da preguiça gigante, ele não conseguiria obter todas as informações sobre o animal, seu ambiente e que isso só foi possível com a observação de todo o conjunto expositivo.

Elisa destacou que, como haviam estudado os Reinos, referindo-se à classificação dos animais, notou a importância de vê-los, não só nos livros, e que isso fazia uma grande diferença para a compreensão desse conteúdo da Biologia. Argumenta que, se o professor levasse aqueles animais observados para a sala de aula, ou mesmo os levassem para uma visita ao museu, compreenderiam não apenas sobre os animais, mas também sobre o ambiente em que vivem, a 
alimentação, a locomoção, dentre outros conceitos científicos. Acrescentou ainda que, ao observarem os objetos nos museus, fica mais fácil compreender o assunto como um todo e não conteúdos fragmentados. Complementou que os textos colocados juntamente com os objetos ajudam a entender melhor o que está exposto, ou seja, um completa o outro.

Rita fez questão de dizer tudo o que observou no objeto pedagógico e no conjunto expositivo, ou seja, que a preguiça gigante viveu no cerrado no período pleistoceno, que era um animal herbívoro por causa do tipo de dentes, próprio para comer folhas, que pertencia à ordem Xenarthra e que se erguia numa posição bípede para se alimentar das folhas das copas das grandes árvores. Acrescenta que os elaboradores da exposição construíram o modelo do esqueleto da preguiça gigante, para preservar os ossos originais, que não podem ficar expostos, ou seja, precisam ser preservados. Ainda argumenta que o objeto pedagógico foi um exemplo para mostrar a seleção natural de Darwin.

Os modelos finais, elaborados pelos cinco jovens, também foram fotografados para atribuirmos comparações entre o modelo inicial e o modelo final, ou seja, para que possamos verificar as concepções que os jovens tinham antes de conhecerem o objeto pedagógico e as concepções que trouxeram após a visita ao museu.

A finalidade da comparação é a de confrontar se as interações dos jovens com o modelo do esqueleto da preguiça gigante vão ao encontro das intenções propostas pelos idealizadores do conjunto expositivo em questão. Esse fato poderá contribuir para o alcance dos objetivos gerais da pesquisa, ou seja, apontar o papel pedagógico dos objetos em exposições de museus, caracterizar o potencial do 
objeto em expressar determinados conhecimentos científicos ao ser apresentado em uma exposição de museu e identificar aspectos relacionados aos conceitos científicos que os sujeitos são capazes de perceber ao observar o objeto em uma exposição.

\subsubsection{Os modelos finais dos jovens}

\section{Modelo final de Elisa}

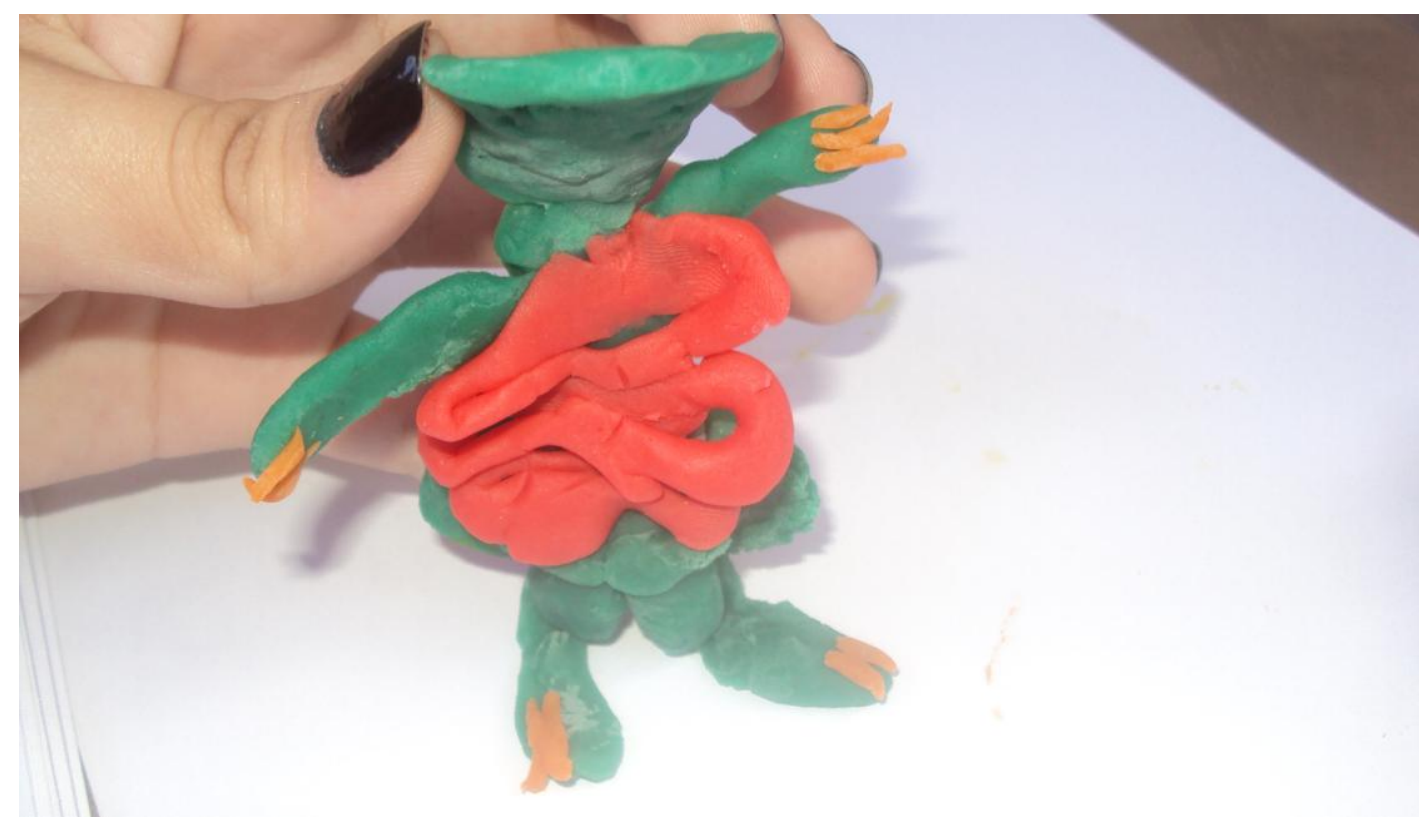

FIGURA 30: Modelo final de Elisa.

Fonte: Acervo da pesquisadora.

O modelo final de Elisa apresenta uma tentativa importante da jovem em melhorar o modelo inicial que havia construído. Nessa etapa, o modelo contém quatro patas com três garras nas patas dianteiras e duas garras nas patas traseiras e esqueleto bem definido. Não mais definiu no modelo final os olhos e a boca e o colocou numa posição bípede. 
Ana Maria Senac Figueroa

OS OBJETOS NOS MUSEUS DE CIÊNCIAS:

o papel dos modelos pedagógicos na aprendizagem

\section{Modelo final de João}

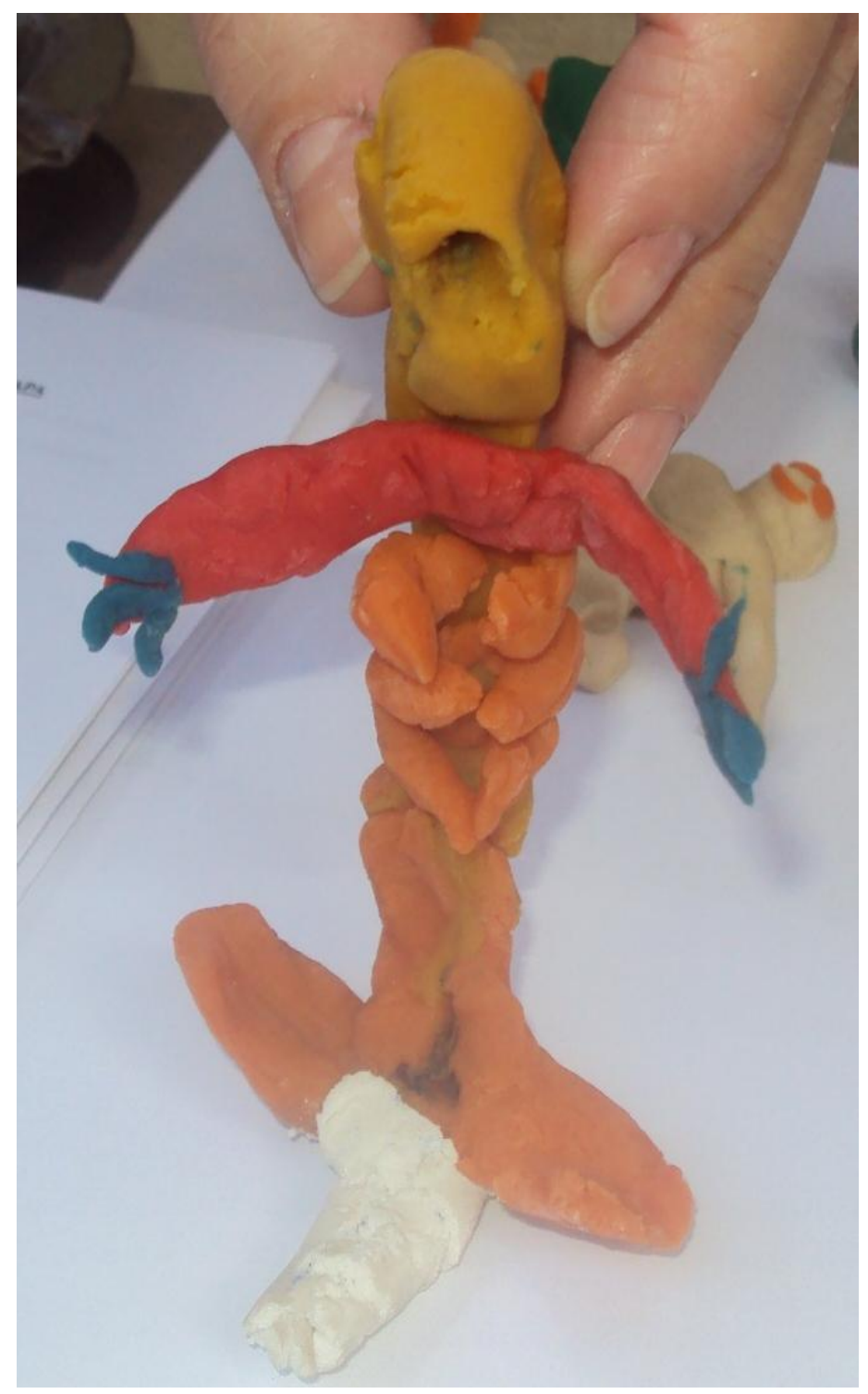

FIGURA 31: Modelo final de João

Fonte: Acervo da pesquisadora

O modelo final de João apresenta quatro patas com três garras apenas nas patas dianteiras e esqueleto representado por costelas à mostra. Não mais definiu olhos e boca, porém representou as cavidades dos mesmos. Nesse modelo final, João não representou o nariz nem a sua cavidade e colocou o modelo em posição bípede como observado no museu. Acrescentou uma cauda com tamanho aumentado. 
Ana Maria Senac Figueroa

OS OBJETOS NOS MUSEUS DE CIÊNCIAS:

o papel dos modelos pedagógicos na aprendizagem

\section{Modelo final de Marina}

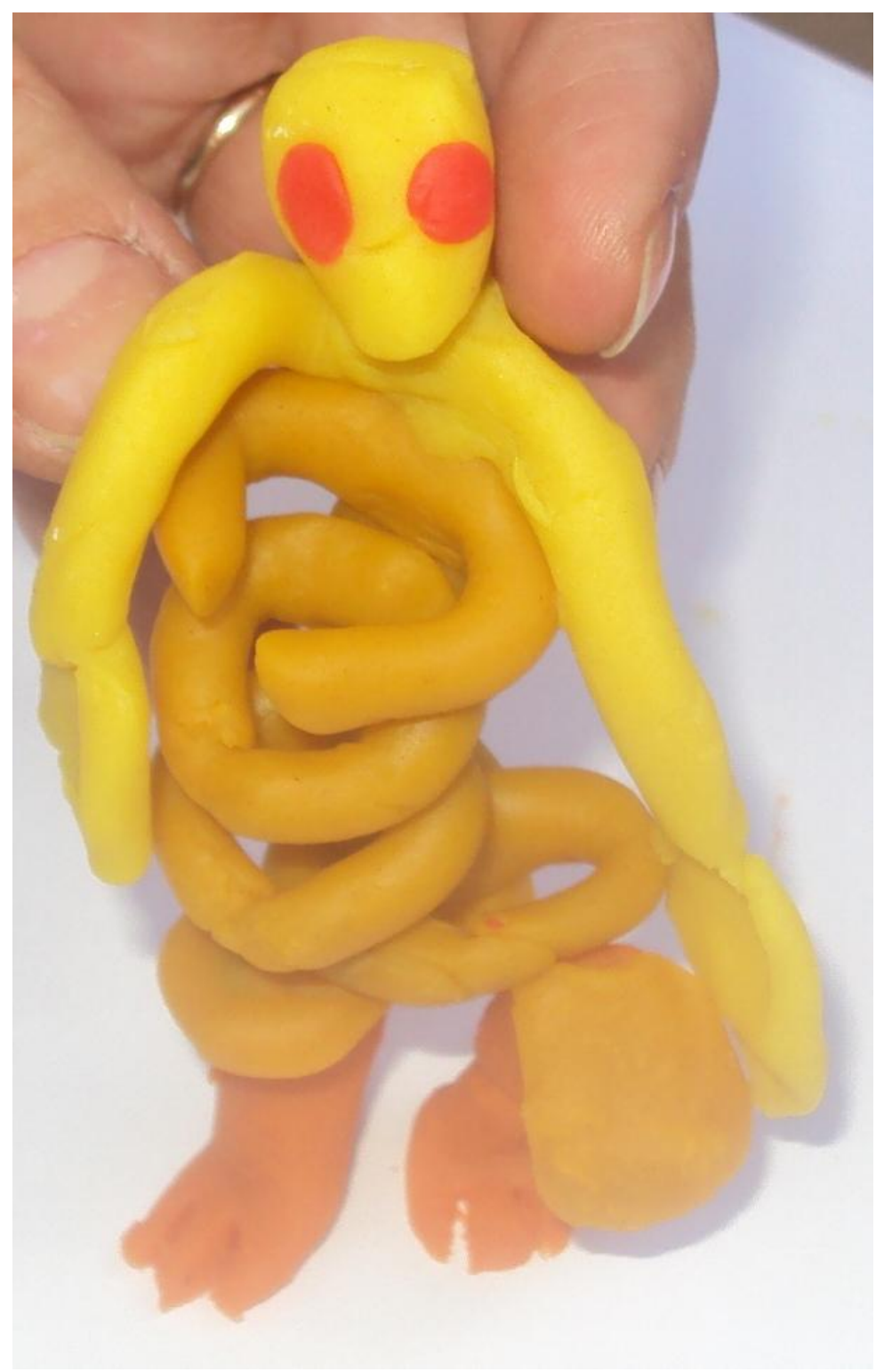

FIGURA 32: Modelo final de Marina.

Fonte: Acervo da pesquisadora.

O modelo final de Marina apresentou quatro patas longas com três garras e esqueleto com costelas bem salientes. Definiu o que parece ser a cavidade ocular, e colocou o modelo numa posição bípede, como observado no museu. 
Ana Maria Senac Figueroa

OS OBJETOS NOS MUSEUS DE CIÊNCIAS:

o papel dos modelos pedagógicos na aprendizagem

\section{Modelo final de Rita}

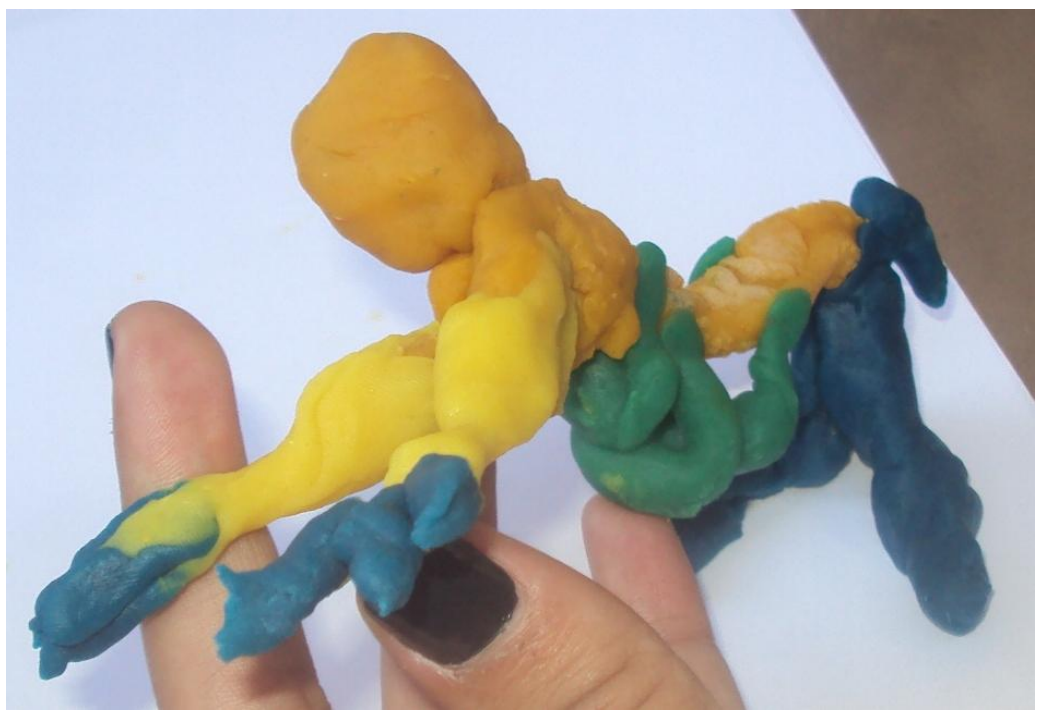

FIGURA 33: Modelo final de Rita.

Fonte: Acervo da pesquisadora.

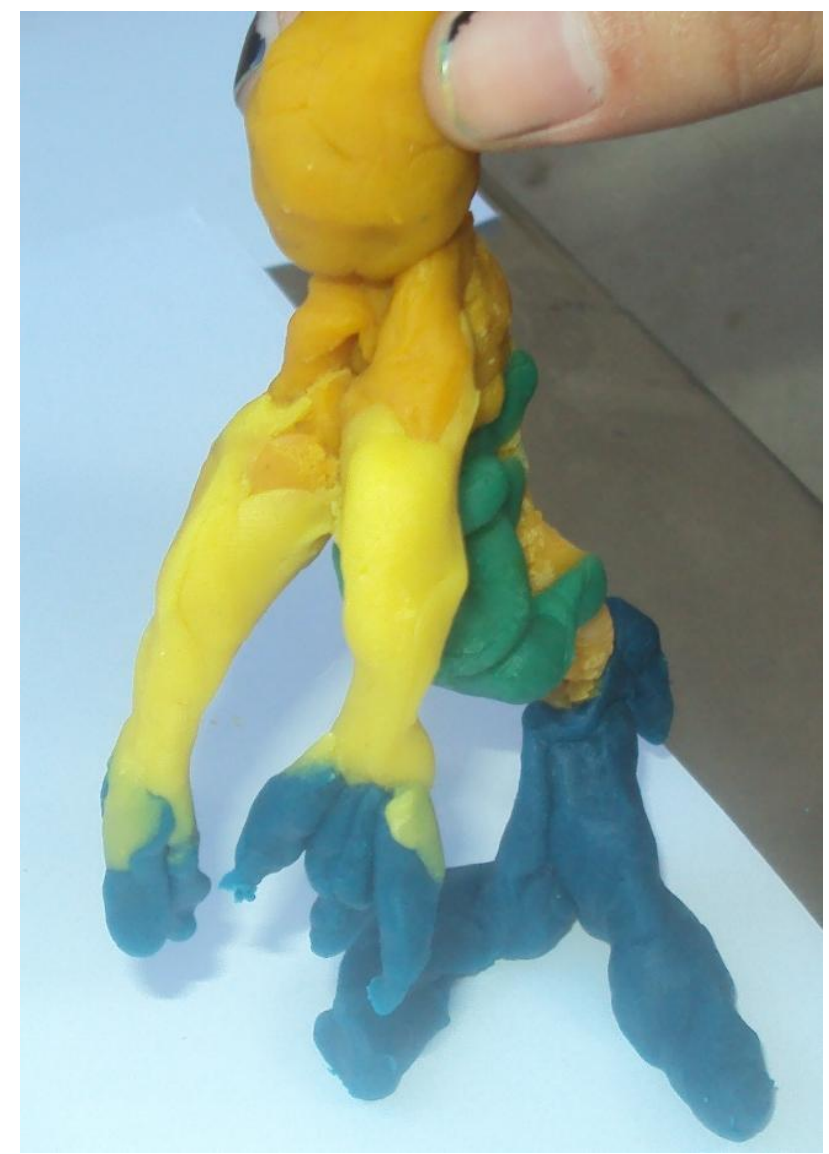

FIGURA 34: Modelo final de Rita

Fonte: Acervo da pesquisadora. 
Rita apresentou um modelo bem diferente do modelo inicial. O modelo final de Rita apresenta, agora, o esqueleto da preguiça gigante, com costelas bem visíveis, conforme o visto no museu, quatro patas com três garras em cada pata dianteira e o apresenta em posição bípede.

\section{Modelo final de Anita}

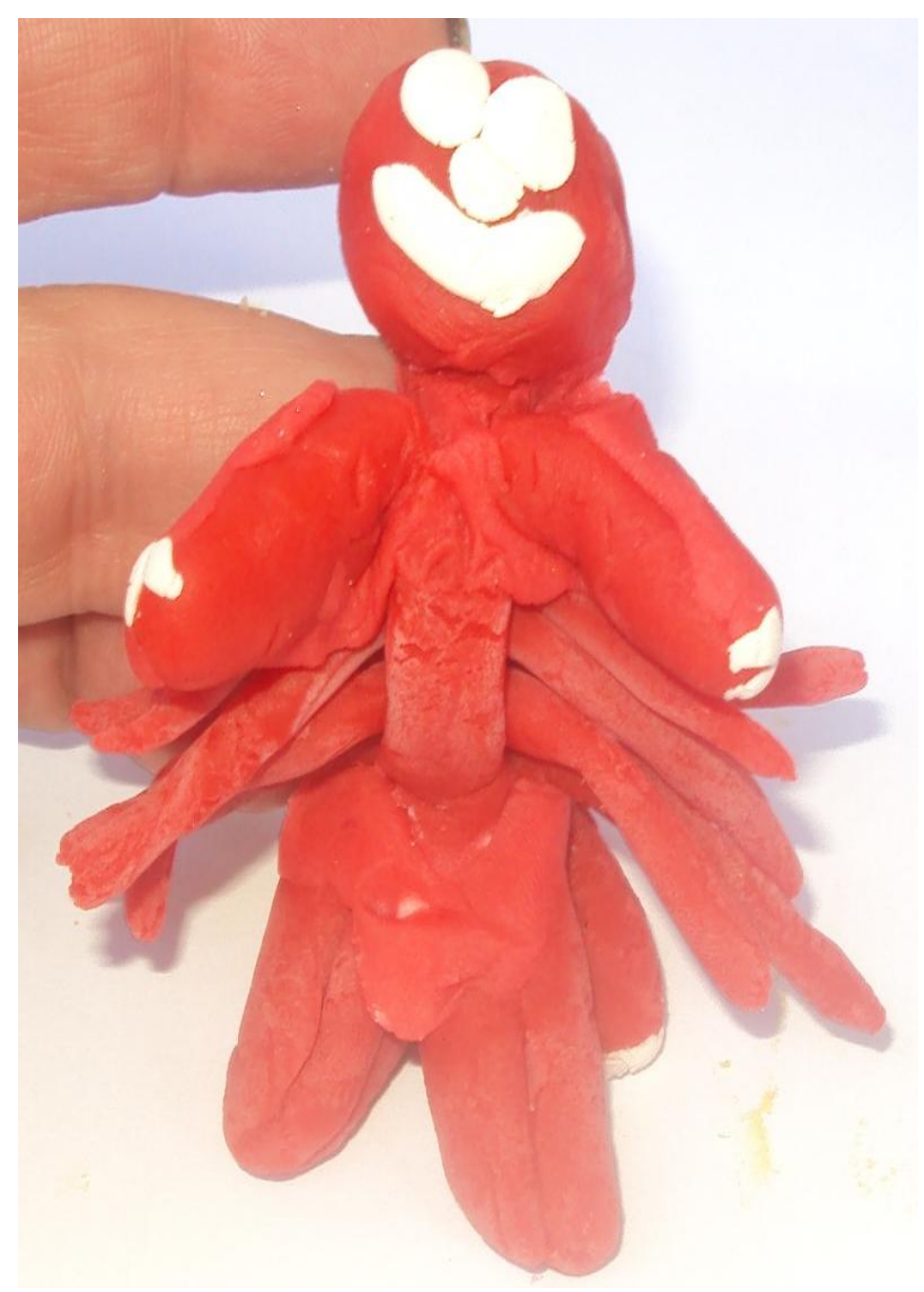

FIGURA 35: Modelo final de Anita.

Fonte: Acervo da pesquisadora.

Anita também se esforçou em apresentar um modelo mais próximo do que aquele visualizado no museu. Apresenta, nesta etapa, um modelo com costelas 
Ana Maria Senac Figueroa

OS OBJETOS NOS MUSEUS DE CIÊNCIAS:

o papel dos modelos pedagógicos na aprendizagem

visíveis, quatro patas com três garras nas patas dianteiras. A posição do modelo é bípede e Anita refaz os olhos, boca e nariz, e não suas cavidades como constam no objeto do museu.

No capítulo a seguir e, levando em conta a revisão da literatura, os dados coletados e apresentados, bem como os possíveis elementos de análise, poderão responder às nossas questões de pesquisa. Iremos, portanto, articular os dados oriundos do conjunto do "nosso olhar" e do "olhar do museu" e analisá-los a partir dos dois eixos relacionados às dimensões da aprendizagem, mencionados anteriormente. Analisaremos, também, os dados obtidos com relação às interações de cada jovem com o objeto pedagógico e com todo o conjunto expositivo, a partir dos dois eixos das dimensões da aprendizagem. 
DAS INTENÇÕES DO MODELO ÀS INTERAÇÕES DOS JOVENS 


\section{DAS INTENÇÕES DO MODELO ÀS INTERAÇÕES DOS JOVENS}

Nessa pesquisa, como anunciado anteriormente, focalizamos tanto as dimensões relacionadas aos produtos - eixo conceitual, como às relacionadas ao processo - eixo processual - de aprendizagem. Portanto, levamos em conta a revisão da literatura realizada e analisamos o modelo pedagógico do esqueleto da preguiça gigante e o conjunto expositivo onde está inserido a partir desses dois eixos que buscam expressar ambas as dimensões - produto e processo - da aprendizagem.

Iremos utilizar os referidos eixos tanto para analisar as intenções do museu ao elaborar a exposição estudada, quanto para analisar as interações dos jovens com o modelo e o conjunto expositivo, buscando perceber as possíveis articulações e distâncias entre elas.

Assim, retiramos dos dados coletados, apresentados no capítulo anterior, os possíveis elementos de análise que puderam responder às nossas questões de pesquisa, quais sejam:

- Qual a influência do modelo pedagógico do museu na aprendizagem?

- $\quad$ Até que ponto as intenções do modelo pedagógico são incorporadas nos modelos produzidos pelos jovens pesquisados? 


\subsection{ANÁLISE DAS INTENÇÕES: NOSSO OLHAR E O OLHAR DO MUSEU SOBRE O OBJETO}

Nesse item iremos articular os dados oriundos do conjunto do "nosso olhar" e do "olhar do museu" sobre o modelo do esqueleto da preguiça gigante e o conjunto expositivo onde se encontra e analisá-los a partir dos dois eixos relacionados às dimensões da aprendizagem.

\subsubsection{Eixo Conceitual}

No eixo conceitual, que busca expressar as dimensões dos produtos da aprendizagem, buscamos destacar nas intenções do objeto e do conjunto expositivo, de acordo com o nosso olhar e o olhar do museu, os itens relacionados às características biológicas e ecológicas do objeto em estudo, assim como seu contexto geológico.

Desse modo, as características biológicas, como o tamanho, a locomoção e a alimentação, estão expressas no objeto e compõem o eixo conceitual relativo às intenções da exposição. Tais características podem ser indicadas como a locomoção pedolateral, as patas com três garras e os dentes, que em forma de tesoura, auxiliam a coleta de folhas nos topos das arvores. Ainda estamos considerando nesse eixo itens relacionados à fisiologia do animal, como a sua reprodução e sua classificação biológica, já que a preguiça-gigante pertence à ordem Xenarthra.

Quanto às características ecológicas inseridas no eixo conceitual, consideramos que aspectos relacionados à perda da diversidade pretérita são um mote para a compreensão dos problemas relativos à perda da diversidade atual e 
futura. Ainda aqui, consideramos também o fato de que o modelo do esqueleto da preguiça gigante é um símbolo do cerrado mineiro. Desse modo, tanto a questão da extinção, quanto os aspectos relacionados à perda da biodiversidade estão incluídos entre as intenções do conjunto expositivo analisado.

No contexto geológico, incluímos as informações sobre o tempo geológico, já que o modelo da preguiça gigante foi produzido a partir de um fóssil encontrado no Brasil. As reduções das florestas, que consequentemente ampliaram as áreas de cerrado, ou seja, seu habitat natural, também foi considerado. A fauna e a flora da época e os sítios de fósseis dos dinossauros encontrados no Brasil são aspectos também mencionados na exposição e na fala do entrevistado, compondo assim o eixo conceitual das intenções do objeto em análise.

Dessa forma, o objeto pedagógico, ou seja, o modelo do esqueleto da preguiça gigante encerra não apenas informações pontuais, mas uma gama de conceitos ligados à sua estrutura e ambiente e, o conjunto expositivo o contextualiza em meio à exposição.

\subsubsection{Eixo Processual}

No eixo processual, serão apontadas as intenções do objeto e do conjunto expositivo relativo aos modos como os sujeitos interagem com os objetos e entre eles, considerando que esses aspectos são cruciais para compreensão da aprendizagem nos museus. Para tal, buscamos identificar aspectos promotores de curiosidade, motivação, imaginação e memória presentes tanto na fala do entrevistado como em nossas observações da exposição, com a finalidade de caracterizar as intenções relacionadas ao eixo processual da aprendizagem. 
Um primeiro elemento merecedor de destaque é o fato de que o modelo do esqueleto da preguiça gigante é uma das grandes "estrelas" da exposição e está localizado em posição bípede, demonstrando altivez e grandeza. Essa representação pode despertar a curiosidade e motivar a visita, além da busca por mais informações. O modelo e os elementos ao se redor resgatam, ainda, o passado e as características do ambiente em que esse animal viveu, o que pode promover o desenvolvimento da imaginação pelos visitantes. Informações do modelo da preguiça gigante propriamente dito, contidas, por exemplo, nas ranhuras dos ossos e nas marcas de terra que ele possui, assim como na posição bípede em que está colocado e também nas reconstituições biológicas (modelos de animais em resina) que compõem o conjunto expositivo são potencialmente promotoras de questionamentos, promovendo a curiosidade pelo tema.

Além das características apontadas acima, é pertinente ressaltar aspectos na exposição que podem levar ao questionamento e ao diálogo entre os sujeitos, promovendo debates e levantando dúvidas sobre as informações oferecidas. Assim, estamos considerando que o modelo e o conjunto expositivo onde está inserido, incluindo os demais objetos além da própria preguiça gigante e os textos, podem promover a interação interpessoal - elemento fundamental para formação do cidadão. Por exemplo, as questões relacionadas à perda da biodiversidade podem promover a reflexão sobre aspectos ligados mudança de atitude e de valores, a partir de temas que o conjunto expositivo suscita, como questões ligadas à conservação.

Aspectos relacionados aos processos de aprendizagem por investigação como a observação, a descrição, a discussão, o levantamento de hipóteses e a 
expressão dos conhecimentos prévios dos jovens - também foram considerados nesse eixo processual de aprendizagem. Analisando o conjunto expositivo, consideramos que as informações fornecidas possuem potencial de promover tais aspectos no museu. Tanto no que se referem aos conceitos científicos presentes em objetos e textos, quanto às informações referentes aos processos de produção do conhecimento científico, promovem a possibilidade do visitante realizar observações, revelar suas concepções sobre os temas em jogo e levantar hipóteses.

As informações sobre a pesquisa em torno do objeto exposto, sobre a coleta dos objetos pertencentes ao acervo do museu e sobre a própria elaboração do modelo trazem conteúdos relacionados à história da ciência e da paleontologia, assim como da história dos naturalistas de Minas Gerais, expressando conteúdos referentes à maneira como produção científica ocorre. Por meio das informações contidas no objeto e nos textos, é possível conhecer como os cientistas estudam temas relacionados à paleontologia, à evolução, à ecologia, entre outros.

Além disso, a representação do ambiente pintado no grande painel fornece informações sobre o contexto biológico e geológico do animal. Consideramos, ainda, a maneira com que o objeto está exposto: por ser contemplativo, é possível promover a realização de comparações com outros objetos do museu. Tais conteúdos possuem potencial de promover os elementos associados à aprendizagem por investigação ao longo da visita, tanto na interação entre os visitantes quanto destes com os elementos expostos.

Ainda, levamos em conta, neste eixo processual, as várias formas de agir do público ao longo da visita à exposição, ao interagir com os objetos nas vitrines, com os textos nas legendas e com as imagens nos painéis que compõem o conjunto 
expositivo em questão. A leitura dos textos e das placas com os nomes científicos, a observação dos fósseis originais que compõem as vitrines e das imagens representadas nos painéis podem acrescentar significados importantes no que se refere à dimensão procedimental da aprendizagem.

O fato de que quase todo o acervo exposto do museu é baseado em modelos e réplicas para salvaguardar os originais é relevante para compreensão do significado de um museu de ciências. Esse tema envolve questões relacionadas às permutas interinstitucionais de fósseis originais e dos moldes para a produção dos modelos, bem como às discussões sobre a propriedade intelectual. Neste sentido, é pertinente lembrar que o próprio modelo do esqueleto da preguiça gigante é uma analogia estrutural, uma cópia fiel do fóssil encontrado com a premissa de ter sido feito para ensinar. Os aspectos mencionados, se percebidos pelos visitantes, auxiliam na compreensão da cultura museal.

\subsection{ANÁLISE DAS INTERAÇÕES DOS JOVENS COM O OBJETO: ANTES, DURANTE E DEPOIS DA VISITA}

Neste item, iremos analisar os dados obtidos com relação às interações de cada jovem com o objeto pedagógico e todo o conjunto expositivo. Para tal, consideramos três momentos de coleta de dados, correspondentes

i) ao levantamento das ideias dos jovens a partir da modelagem em massa da preguiça gigante antes da visita ao museu;

ii) à interação dos jovens com o modelo da preguiça gigante durante a visita; 
iii) à produção de nova modelagem da preguiça gigante em massa após a visita. Para cada momento os dados foram analisados com base nos dois eixos aprendizagem adotados, ou seja, o eixo conceitual e o eixo processual.

A finalidade foi, com esta análise, responder à questão central dessa pesquisa, ou seja, o papel do modelo do esqueleto da preguiça gigante na aprendizagem de jovens em visita ao museu, na busca pela compreensão da função educativa dos modelos/objetos pedagógicos nos museus de ciências.

\subsubsection{Jovem Elisa}

A jovem Elisa possui 17 anos de idade e está no segundo ano do ensino médio. Já havia visitado o Museu de Ciências Naturais da PUC-Minas e, portanto, já conhecia o modelo do esqueleto da preguiça gigante, objeto de nosso estudo.

\section{$1^{\text {a }}$ etapa: antes da visita}

Com relação ao eixo conceitual, Elisa, ao elaborar o seu modelo inicial, considerou características biológicas como coluna vertebral, muitos membros, sendo que em cada membro colocou duas garras. Também considerou que o modelo possuía uma cabeça completa, com olhos e boca bem definidos. Como já conhecia o modelo exposto no museu, mencionou durante a confecção do modelo em massinha que: "[...] toda vez que vejo esse esqueleto fico impressionada com o seu tamanho", destacando assim uma característica biológica do eixo conceitual de aprendizagem. 
Ainda nessa etapa, a jovem não trouxe à tona nenhum conceito que expressasse as características ecológicas ou o contexto geológico do animal, nem no modelo produzido, nem em sua fala durante sua produção.

Quanto ao eixo processual da aprendizagem, nessa primeira etapa, a jovem enfatizou em sua fala que considera bom ver as "coisas de verdade no museu". No entanto, ao mesmo tempo, afirmou que o modelo da preguiça gigante havia sido feito no museu e que não era de verdade. Essas falas revelam que Elisa já possuía informações sobre o objeto, as quais foram adquiridas em visita anterior ao museu e que puderam ser compartilhadas com os colegas neste momento, promovendo questionamentos sobre o objeto. Corretas ou não, Elisa levou, para a visita ao museu, ideias e dúvidas sobre a veracidade do modelo exposto. Suas "verdades" puderam ser confrontadas com o objeto pedagógico durante a visita à exposição. A fala de Elisa, ao longo da produção do modelo antes da visita, revela o potencial que o objeto possui em levantar questionamentos, sendo este um elemento de motivação e promoção de curiosidade mesmo antes da interação com mesmo no museu.

\section{$2^{\mathrm{a}}$ etapa: durante a visita}

$\mathrm{Na} 2^{\mathrm{a}}$ etapa, durante a visita à exposição, Elisa destacou novamente o tamanho do modelo e afirmou, em sua fala, que a preguiça gigante é um animal bípede, devido ser essa a posição em que se encontra na exposição. Esses aspectos estão relacionados com as características biológicas do eixo conceitual de aprendizagem. 
Relativamente às características ecológicas, Elisa fez referência à ordem Xenarthra que aprendeu na leitura dos textos da exposição e enfatizou que "[...] os textos ajudam na compreensão do conteúdo, pois um completa o outro". Acrescentou também que a preguiça gigante deu origem às preguiças de hoje e fez menção à Era do Gelo, como sendo a Era em que a preguiça gigante viveu, o que consideramos ser uma característica do contexto geológico do eixo conceitual de aprendizagem.

Com relação ao eixo processual de aprendizagem, observamos ao longo da visita que a jovem leu atentamente os textos, o que referenda a sua fala mencionada acima e revela sua compreensão sobre os procedimentos de acesso a informação pelo visitante no espaço do museu, feito por meio dos textos, das imagens, das vitrines e das legendas que compõem o conjunto expositivo.

Ainda, durante a observação da exposição, a jovem Elisa se mostrou inquieta em frente ao modelo do esqueleto da preguiça gigante, manifestando interesse em observar o painel pintado que está colocado ao fundo do conjunto expositivo. O painel, que representa o ambiente em que o animal viveu há 11 mil anos foi, depois do modelo, o que mais interessou e motivou a jovem durante a visita.

"Como os cientistas sabem, só por meio dos fósseis, como era o ambiente daquela época"? Este foi um questionamento de Elisa, enquanto observava o painel pintado com o ambiente em que viveu a preguiça gigante e outros animais do período Pleistoceno, o que desencadeou conversas com os demais colegas. Este fato indica que o conjunto expositivo suscitou questionamentos nesta jovem e promoveu diálogos e discussões acerca dos processos de produção do 
conhecimento, ou seja, sobre a pesquisa, a coleta dos objetos no museu e a própria elaboração do modelo.

Ainda, com relação ao eixo processual de aprendizagem, notamos que durante a visita a jovem mudou sua concepção anterior sobre o modelo da preguiça. Ao observar o objeto pedagógico na exposição, afirmou que ele era "de verdade" e não um modelo, como havia dito na primeira etapa da coleta antes mencionada. Como afirmamos, o modelo do esqueleto da preguiça gigante é uma analogia estrutural, ou seja, uma cópia fiel do fóssil encontrado, o que acaba por promover essas dúvidas e levanta questionamentos sobre a importância da exposição fornecer essas informações ao público. No caso estudado, esta informação não está presente nos textos existentes no conjunto expositivo.

\section{$3^{\mathrm{a}}$ etapa: após a visita}

Na última etapa da pesquisa, ou seja, depois da visita ao museu e durante a produção de seu modelo final em massa de modelar, a jovem Elisa incorporou a cauda do animal na estrutura do modelo, alterou a quantidade de membros para apenas quatro e acrescentou mais uma garra nas patas dianteiras. Além disso, representou a coluna vertebral e acrescentou as costelas à sua representação. Não mais representou olhos e boca na cabeça do modelo.

Assim, percebemos que, após a visita ao museu, a jovem reviu seu modelo inicial, acrescentando elementos pertencentes às características biológicas do modelo, bem como enfatizou que a preguiça gigante ficava em uma posição bípede só para se alimentar das folhas no topo das árvores. Nesta revisão, modificou a sua concepção inicial de que o animal era bípede e notamos que houve maior motivação 
após a visita em melhorar o modelo que construiu inicialmente, procurando adequálo ao modelo do museu.

Ainda nesta terceira etapa, a jovem Elisa não faz nenhuma referência ao contexto geológico e concentrou-se na produção do modelo em massinha.

Quanto ao eixo processual das dimensões da aprendizagem, após a visita, a jovem revelou sua compreensão sobre o papel do esqueleto da preguiça gigante no museu, afirmando que o modelo teria os mesmos propósitos se estivesse colocado em outro lugar: "[...] em qualquer lugar ele iria mostrar que um dia a preguiça gigante existiu".

Após a visita, Elisa voltou a afirmar a importância de ver os objetos no museu para auxiliar na compreensão dos conteúdos escolares. Enfatizou que: “[...] observando os objetos nos museus fica mais fácil de entender a matéria".

A jovem relata também que os textos ajudam na compreensão do assunto e acrescenta que um completa o outro, ou seja, os textos completam o objeto.

\subsubsection{Jovem João}

O jovem João possui 16 anos de idade e está no segundo ano do ensino médio. Assim como Elisa, já havia visitado o Museu de Ciências Naturais da PUCMinas e também conhecia o modelo do esqueleto da preguiça gigante. 
Ana Maria Senac Figueroa

OS OBJETOS NOS MUSEUS DE CIÊNCIAS:

o papel dos modelos pedagógicos na aprendizagem

\section{1aㅡ etapa: antes da visita}

Com relação ao eixo conceitual, João construiu o seu modelo inicial considerando características biológicas, produzindo um animal com quatro membros e sem nenhuma garra. Considerou um corpo para o modelo e, na cabeça, definiu os olhos, a boca e o nariz da preguiça gigante e, ainda, o colocou em posição bípede, assim como está exposto no museu.

João, como já conhecia o Museu de Ciências Naturais da PUC-Minas, trouxe à tona, nessa primeira etapa, conceitos que expressam as características biológicas do eixo conceitual de aprendizagem, quando comentou, por exemplo: "[...] eu acho legal ver os esqueletos dos animais e imaginar como os músculos e a pele se colocam sobre eles".

A fala exemplificada anteriormente também revela elementos relacionados ao eixo processual da aprendizagem, já que percebemos que o objeto promoveu o desenvolvimento da imaginação e da memória mesmo antes da realização da visita, o que foi também potencializado pelo fato de que João já conhecia a exposição.

Durante a produção do modelo em massa de modelar antes da visita ao museu, o jovem não ressaltou, nem em sua fala e nem no modelo em si, as características ecológicas e o contexto geológico em que a preguiça gigante viveu.

Ele não levantou questionamentos na primeira etapa da pesquisa, mas se mostrou eufórico para sair em visita ao museu, revelando motivação e curiosidade em rever a exposição. 
Ana Maria Senac Figueroa

OS OBJETOS NOS MUSEUS DE CIÊNCIAS:

o papel dos modelos pedagógicos na aprendizagem

\section{2a etapa: durante a visita}

No início da visita à exposição, João afirmou novamente ter a preguiça gigante uma locomoção bípede. No entanto, durante a interação com o conjunto expositivo em que o modelo do esqueleto está inserido, refez sua ideia e indicou ser a preguiça gigante um animal quadrúpede. Estes dados expressam aspectos tanto relacionados ao eixo conceitual quanto ao eixo processual de aprendizagem, pois estamos considerando o tipo de locomoção do referido animal, bem como a interação e observação do objeto pelo jovem frente à exposição.

Nesta etapa da pesquisa, João não demonstrou interesse em ler os textos que compõem o conjunto expositivo. Mostrou-se, contudo, interessado em observar o painel pintado que está colocado ao fundo da exposição. Na frente do painel, o jovem apontou para a imagem da preguiça na posição bípede, alimentando-se de folhas da copa de uma árvore e afirmou: "Ela só fica em posição bípede para se alimentar, mas é quadrúpede". Neste momento evidenciou-se a mudança em sua concepção inicial de que a preguiça tinha uma locomoção bípede, expressando desse modo aspecto referente ao eixo conceitual de aprendizagem, no que diz respeito às características biológicas do referido animal.

Ainda durante a visita, João observou "emendas" em outros modelos de esqueletos existentes no museu, mais precisamente no modelo do esqueleto da baleia. Ao perceber esse fato, no modelo da baleia, o jovem acrescentou: "[...] esse animal foi montado aqui no museu porque dá pra ver as emendas... deve ter uns pedaços do animal mesmo e uns pedaços eles fizeram com gesso...". Este dado nos fez perceber que o jovem pôde confrontar a sua concepção inicial de que os modelos não eram de "verdade" com evidências expressas nos próprios objetos e 
que o levaram a perceber que se tratava de modelos reconstruídos. Considerando que o acesso a essa informação pelo jovem é fundamental para compreensão da produção de conhecimento em paleontologia, verifica-se o potencial que o objeto tem em expressar o eixo processual de aprendizagem.

Com relação ao eixo processual de aprendizagem, João demonstrou interesse pelo painel pintado e ressaltou: "Eu não poderia aprender muito sobre a preguiça gigante só observando o esqueleto, o objeto... eu só aprendi mais sobre ela depois que vi o painel, né?". Nesse momento, João tomou consciência de que na exposição não somente 0 modelo fornece todas as informações e que são importantes também os demais elementos do conjunto expositivo, para complementar aquilo que objeto por si só não é capaz de revelar.

\section{$3^{\text {a }}$ etapa: após a visita}

Depois da visita ao museu, ao produzir seu modelo em massinha, João incorporou as três garras aos membros do animal na estrutura e não mais representou um corpo, mas sim um esqueleto com as costelas visíveis. Além disso, não mais definiu os olhos, a boca e o nariz, mas representou as cavidades do esqueleto como o modelo no museu. Acrescentou ainda um aumento na cauda do modelo final.

Assim, percebemos que, após a visita ao museu, o jovem fez uma revisão de seu modelo inicial, acrescentando e retirando elementos pertencentes às características biológicas do modelo, bem como revendo suas concepções iniciais sobre a locomoção do animal. 
Nessa terceira etapa, João não fez nenhuma referência às características ecológicas e ao contexto geológico, do eixo conceitual de aprendizagem, concentrando-se na elaboração do modelo em massinha.

Ainda, após a visita ao museu, o jovem revela que: "Eu não conheço jeito melhor em compreender os conteúdos de ciências senão por meio de objetos nos museus". Com esta afirmação, João expressou afetivamente o quanto a visita havia o mobilizado, valorizou o papel do museu e, em especial, dos objetos para a compreensão da ciência. Esse dado se insere no eixo processual de aprendizagem, pois revela que para João a experiência, a visita e o objeto no museu envolvem elementos como motivação e interesse, além de promover ações relacionadas à observação, expressão dos conhecimentos prévios, descrição e discussão.

O jovem também revelou nessa última etapa da pesquisa que não mais tinha nenhuma dúvida sobre a autenticidade do modelo do esqueleto da preguiça gigante, ou seja, "[...] tenho certeza que essa preguiça é feita aqui no museu, assim como a baleia..." "[...] eu vi as emendas no esqueleto da baleia, eles fazem os esqueletos aqui". Essa fala evidencia a importância da análise do objeto feita por João na visita, o que está diretamente ligado ao eixo processual de aprendizagem e demonstra, mais uma vez, a importância da exposição em fornecer esse tipo de informação ao público visitante.

\subsubsection{Jovem Marina}

A jovem Marina, com 17 anos de idade, cursa o $2^{0}$ ano do ensino médio. Ela nunca havia visitado o Museu de Ciências Naturais da PUC-Minas, mas já tinha 
visitado outros museus como o Museu de Ciências Morfológicas da Universidade Federal de Minas Gerais.

Marina mencionou que esperava encontrar no museu animais, esqueletos, corpo humano e bichos empalhados. Fez também uma comparação com o museu da UFMG, dizendo que: "[...] lá tem um cadáver com olho de vidro, um olho azul, parece... o olho é de mentira, mas o cadáver é de verdade. No museu da PUC também deve ter coisas de mentira e coisas de verdade, eu acho".

\section{1aㅡ etapa: antes da pesquisa}

Nesta primeira etapa, a expectativa de Marina em relação à visita ao museu foi importante para motivá-la a elaborar o seu modelo em massinha de modelar. Durante a produção, a jovem expressou sua intenção de comparar o modelo que estava elaborando com o modelo do museu, enfatizando que "Este modelo que vou fazer agora vou comparar com o que está lá no museu...". Mais uma vez vemos que o objeto - e a possibilidade de pensar e levantar ideias sobre ele antes da visita promove a motivação, o interesse, vontade de realizar comparações, o que revela aspectos do eixo processual de aprendizagem.

A jovem Marina, ainda antes da produção do seu modelo em massinha de modelar, ressaltou em sua fala que já havia visto uma preguiça, mas não sabia se era a preguiça gigante, dizendo: "[...] acho que não... eu a imagino com uma cor cinza, toda lenta, com três dedinhos e unhas bem grandes". Acrescentou também que a preguiça possuía uma "carinha" e um "focinho pequeno", e que a imaginava um animal muito perigoso. 
Esses elementos ressaltados pela jovem expressam importantes aspectos do eixo processual de aprendizagem, como os conhecimentos prévios, a imaginação e a memória. A motivação em torno do objeto levou-a a expressar suas ideias sobre a preguiça aos colegas, o que acabou promovendo discussões entre a Marina e os outros jovens e também com a pesquisadora. Além disso, expressou características biológicas e ecológicas do eixo conceitual de aprendizagem nessas falas iniciais, com elementos que estavam em sua imaginação e em sua memória, bem como, se mostrou fortemente motivada em produzir o modelo de massinha.

Marina considerou, ao elaborar o seu modelo inicial, características biológicas do eixo conceitual de aprendizagem, tais como, corpo definido, quatro membros com três garras em cada um, cabeça e olhos bem definidos. A jovem ainda apresentou o modelo numa posição bípede.

Com relação ao contexto ecológico da preguiça gigante, a jovem considerou nesta etapa inicial o habitat do animal, produzindo com a ajuda da massa um ambiente com árvores e frutos. Expressou, assim, mais uma vez, aspectos tanto da imaginação como de conhecimentos prévios, pertencentes ao eixo processual de aprendizagem.

\section{2a etapa: durante a visita}

Na segunda etapa, durante a visita ao Museu de Ciências Naturais da PUCMinas, Marina, ao ver o modelo do esqueleto da preguiça gigante, expressou o seu desconhecimento sobre a existência da cauda do animal. Neste momento, a jovem identificou, com a ajuda do modelo exposto, uma das características biológicas do animal. 
Assim como os outros jovens, Marina também revelou durante a visita que o modelo do esqueleto da preguiça gigante era autêntico, mas mudou a sua concepção inicial, após a observação do modelo e dos demais elementos do conjunto expositivo. A discussão com relação à autenticidade do modelo pedagógico faz parte das características do eixo processual de aprendizagem, visto que é um elemento fundamental do próprio modelo para a compreensão da produção da ciência e do papel dos objetos nos museus.

Ainda nesta segunda etapa, após a visita a todo conjunto expositivo, Marina modificou a sua concepção inicial de que a preguiça gigante era bípede. Esse aspecto está relacionado ao eixo conceitual de aprendizagem, especialmente relacionado à locomoção do animal. Está, também, expressando aspectos do eixo processual de aprendizagem quando promove, por parte da jovem, a discussão e a observação e propicia a expressão dos seus conhecimentos prévios.

\section{$3^{\text {a }}$ etapa: após a visita}

Depois da visita ao museu, ou seja, na última etapa da pesquisa, a jovem Marina incorporou em seu modelo final quatro patas longas no lugar nas patas curtas que havia modelado anteriormente, com três garras em cada uma. Acrescentou costelas proeminentes ao modelo de massinha, bem como definiu cavidades oculares em um crânio bem definido. Colocou, ainda, o modelo em uma posição bípede, como está exposto no museu.

Assim, percebemos que após a visita ao museu e do contato com o objeto, Marina pôde rever seu modelo inicial, acrescentando e retirando elementos pertencentes às características biológicas do modelo. Ressaltou ainda que colocou o 
modelo de massinha numa posição bípede para se assemelhar ao modelo do museu, mas enfatizou que a preguiça gigante tinha uma locomoção quadrúpede. Portanto, Marina modificou o seu modelo inicial de que o animal era bípede.

Marina expressou ao longo dessa terceira etapa que achava que a preguiça gigante era menor. Enquanto produzia o modelo em massinha de modelar, mencionou que os conceitos acerca do objeto ficaram bem claros para ela e expôs: "[...] a preguiça gigante pertence à ordem Xenartha, é quadrúpede e viveu há 11 mil anos atrás". Afirmou, ainda, que a preguiça gigante foi um animal herbívoro. Sua síntese sobre o que aprendeu demonstra aspectos das características biológicas, ecológicas e também do contexto geológico, elementos esses relacionados ao eixo conceitual de aprendizagem.

Finalmente, Marina argumentou que se o esqueleto que está exposto fosse o fóssil original, ela aprenderia da mesma forma, levantando um tema relevante para o processo de aprendizagem por meio de objetos nos museus.

\subsubsection{Jovem Rita}

A jovem Rita, com 17 anos de idade, cursa o $2^{\circ}$ ano do ensino médio. Ela não conhecia nenhum museu de ciências antes da visita ao Museu de Ciências da PUC-Minas.

Rita não quis se posicionar quanto ao que esperava encontrar no museu e disse: "[...] só indo lá prá ver, né". Por sua vez, comentou que já havia assistido ao filme "A Era do Gelo", mas enfatizou que a preguiça do filme não era a preguiça gigante. Inferiu que a preguiça poderia ser preguiçosa e que ela não existe mais. 
Ana Maria Senac Figueroa

OS OBJETOS NOS MUSEUS DE CIÊNCIAS:

o papel dos modelos pedagógicos na aprendizagem

\section{1a etapa: antes da pesquisa}

Em seu modelo inicial, Rita representou o corpo do animal bem definido, abraçado a uma árvore, como se estivesse se alimentando das folhas, o que revelou seus conhecimentos referentes às características ecológicas e biológicas do animal.

Ainda, na primeira etapa da pesquisa, ao elaborar o seu modelo em massinha, considerou características biológicas como a presença de quatro patas sem as garras e colocou o modelo em uma posição bípede, expressando aspectos do eixo conceitual de aprendizagem.

Do mesmo modo, no que se refere às características ecológicas, Rita afirmou que "a preguiça gigante teve um importante papel no planeta, há 11 mil anos, ou seja, ela não existiu à toa, sem um papel" e complementou a fala anterior dizendo que "a preguiça gigante fazia parte de uma cadeia alimentar e desapareceu por causa de mudanças climáticas”.

Quanto ao eixo processual de aprendizagem, ainda nessa primeira etapa, a jovem enfatizou que apenas conhecia a "preguicinha normal", e que nunca havia visto uma preguiça gigante. Rita, nessa primeira etapa, formulou uma questão e em seguida respondeu à própria questão: "Sabe o que aconteceu com ela? Houve a seleção natural, a de Darwin, onde os bichos tinham que se adaptar ao meio. A partir dessa preguiça gigante é que se deu a origem da preguicinha normal, que nem aquele lance do pescoço da girafa". Assim, percebemos que Rita, ao ser questionada sobre o objeto que seria modelado, e, posteriormente visto no museu, resgatou conhecimentos anteriores, mesmo que errôneos sobre o mesmo. 
$\mathrm{Na}$ fala da jovem ao longo desta primeira etapa, pudemos perceber elementos da sua imaginação, memória, bem como aspectos de conhecimentos prévios, de interação e diálogo com os outros jovens. Esses elementos indicam que o objeto e a possibilidade de modelá-lo antes mesmo da visita ao museu, promoveram em Rita muita curiosidade, interesse e motivação, como veremos na próxima etapa.

\section{2a etapa: durante a visita}

Durante a visita à exposição, a jovem Rita destacou novamente que, pelo tamanho do animal, ele teve um papel muito importante há 11 mil anos. No entanto, ela não foi capaz de dizer exatamente a importância do animal para o ambiente.

Com relação ao papel do modelo do esqueleto da preguiça gigante na exposição, Rita questiona: “[...] se a preguiça estivesse na Praça Sete (praça situada no centro da cidade de Belo Horizonte) as pessoas iriam ficar pensando sobre ela, assim como nós estamos pensando... não iam?". Esse questionamento nos faz perceber que a jovem trouxe à tona aspectos relacionados com o modelo em si e revelou que o objeto pedagógico promove questionamentos e instiga o público a pensar sobre ele.

Durante a visita à exposição, ao se deparar com outra espécie de preguiça, Rita percebeu que seu modelo se assemelhava mais ao modelo de outra espécie de preguiça, a terrícola, e que não tinha representado o esqueleto da preguiça gigante. Neste momento, revelou imediatamente que havia se equivocado. Neste episódio, a jovem realizou uma comparação entre o modelo produzido previamente por ela e aqueles existentes no museu e se preocupou em rever o seu modelo inicial. Este 
Ana Maria Senac Figueroa

OS OBJETOS NOS MUSEUS DE CIÊNCIAS:

o papel dos modelos pedagógicos na aprendizagem

fato coloca em relevo aspectos do eixo processual de aprendizagem, já que expressa o interesse e a motivação da jovem e aponta a possibilidade de expressar os seus conhecimentos prévios sobre o tema.

\section{$3^{\text {a }}$ etapa: após a visita}

Rita fez questão de expressar, nesta etapa, o que observou e compreendeu do objeto pedagógico e do conjunto expositivo. Afirmou que a preguiça gigante viveu no cerrado, no período do pleistoceno e que era um animal herbívoro por causa do tipo de dentes que possuía, ou seja, próprios para se alimentar de folhas das copas das grandes árvores. Acrescentou ainda que a preguiça gigante pertence à ordem Xenarthra e que se ergue em uma posição bípede para se alimentar das folhas das árvores. Esses aspectos ressaltados pela jovem Rita estão relacionados às características biológicas e ecológicas, bem como ao contexto geológico, elementos do eixo conceitual de aprendizagem.

Nesta última etapa da pesquisa, ou seja, após a visita ao museu, a jovem argumentou que não imaginava ser a preguiça gigante tão grande. Ressaltou que descobriu que tudo no museu era "falso" e que só os animais, representantes do ambiente marítimo, eram "verdadeiros". Tais dados revelam, mais uma vez, os questionamentos referentes à autenticidade que o objeto promove, aspectos esses pertencentes ao eixo processual de aprendizagem. Acrescentou que os elaboradores da exposição construíram o modelo do esqueleto da preguiça gigante para preservar os ossos originais que, segundo ela, não podem ficar expostos e argumentou que o modelo foi um exemplo para mostrar a seleção natural. Os aspectos referentes à fala da jovem nos levam a perceber que ela buscou rever 
Ana Maria Senac Figueroa

OS OBJETOS NOS MUSEUS DE CIÊNCIAS:

o papel dos modelos pedagógicos na aprendizagem

aspectos do eixo processual de aprendizagem, tais como o objetivo do próprio modelo na exposição.

\subsubsection{Jovem Anita}

A jovem Anita, com 17 anos de idade, também cursa o $2^{\circ}$ ano do ensino médio. Ela nunca havia visitado um museu de ciências antes da pesquisa. Uma característica marcante da jovem Anita é a de ser a mais tímida do grupo e, portanto, não se manifestou como os outros jovens.

\section{1 ${ }^{\text {a }}$ etapa: antes da visita}

Ao elaborar o seu modelo em massinha de modelar, Anita considerou características biológicas com um corpo do animal bem definido, sendo que o modelo continha, também, quatro patas com três garras apenas nos membros superiores, olhos e boca bem definidos. A jovem colocou seu animal modelado em uma posição bípede, remetendo assim às características biológicas do eixo conceitual de aprendizagem.

Nesta primeira etapa da pesquisa, a jovem Anita considerou que nos museus de arte as coisas são de "verdade", mas, que nos museus de ciências, ela não sabia se as coisas eram de "verdade" ou "falsas", o que revela aspectos do eixo processual de aprendizagem. 
Ana Maria Senac Figueroa

OS OBJETOS NOS MUSEUS DE CIÊNCIAS:

o papel dos modelos pedagógicos na aprendizagem

\section{2a etapa: durante a visita}

$\mathrm{Na}$ segunda etapa da pesquisa, durante a visita ao museu, Anita, assim como os outros jovens, demonstrou surpresa ao ver o tamanho do modelo do esqueleto da preguiça gigante, aspecto esse referente ao eixo conceitual de aprendizagem.

Anita, ao longo da visita, não se dedicou a leitura dos textos. Mostrou interesse e motivação para visualizar o painel com a pintura do ambiente em que viveu a preguiça gigante, aspectos pertencentes ao eixo processual de aprendizagem.

Nesta etapa da pesquisa, a jovem não levantou dúvidas ou questionamentos acerca do modelo pedagógico e nem de seu conjunto expositivo.

\section{3aㅡ etapa: após a visita}

Após a visita ao museu, Anita incorporou ao modelo de massinha de modelar as costelas visíveis do animal, quatro patas com três garras nas patas dianteiras do esqueleto, remetendo a aspectos das características biológicas do eixo conceitual de aprendizagem. Colocou, ainda, o modelo em posição bípede, assim como está exposto no museu e, novamente refez os olhos, boca e nariz bem definidos, como no seu modelo inicial e diferente do que está no modelo do esqueleto da preguiça gigante do museu.

Durante a produção do modelo final, Anita ficou grande parte do tempo ouvindo os colegas e não interferindo nas falas e nas discussões dos outros jovens, 
o que nos impossibilitou de fazer uma análise mais detalhada de suas interações com o modelo pedagógico.

A jovem generalizou a maioria das respostas, dizendo que havia gostado muito da visita ao museu e que também havia gostado de ver o esqueleto da baleia.

Assim, após analisarmos o conjunto de dados relacionados às interações dos jovens com o modelo do esqueleto da preguiça gigante, antes, durante e depois da visita ao museu, um confronto dessas interações com as intenções do modelo pedagógico se faz necessário nesta etapa da pesquisa.

\subsection{CONFRONTANDO AS INTENÇÕES DO MODELO PEDAGÓGICO COM AS INTERAÇÕES DOS JOVENS: ALGUMAS CONSIDERAÇÕES}

Neste item iremos cotejar os dados oriundos das intenções do objeto com aqueles relativos às interações dos jovens, a partir dos eixos de aprendizagem propostos para a análise: conceitual e processual.

Do ponto de vista do eixo conceitual que compreende as características biológicas do objeto pedagógico, percebe-se que todos os jovens modificaram seus modelos iniciais, expressando nos finais os aspectos estruturais do modelo do esqueleto da preguiça gigante, ou seja, incorporando e/ou retirando elementos como coluna vertebral, costelas, cauda aumentada, bem como garras em seus membros inferiores e superiores.

Assim, percebe-se que a visita e a interação com o modelo exposto no museu promoveu um real interesse dos jovens em modificar os modelos iniciais, 
Ana Maria Senac Figueroa

OS OBJETOS NOS MUSEUS DE CIÊNCIAS:

o papel dos modelos pedagógicos na aprendizagem

aproximando-os daquele observado no museu. Consideramos, pois, que, para expressarem as características biológicas do modelo do museu, o modelo em massinha de modelar foi de extrema importância, já que contribuiu significativamente para que os jovens representassem as estruturas morfológicas, bem como, as confrontassem com o modelo inicial que produziram.

Ainda no eixo conceitual de aprendizagem, na análise das características ecológicas e do contexto geológico referentes ao objeto pedagógico estudado, quatro dos jovens expressaram, quando da elaboração dos modelos finais em massinha de modelar, mudanças em relação ao modelo inicial quanto ao tipo de alimentação, locomoção e ambiente em que a preguiça gigante viveu há 11 mil anos. Esse dado indica que o conjunto expositivo que complementa o modelo do esqueleto da preguiça gigante no museu foi fundamental para a compreensão dos aspectos ecológicos relacionados ao objeto. Como exemplo, na etapa posterior à visita, a jovem Elisa incorporou a posição bípede da preguiça gigante em seu modelo final e explicitou em sua fala que a preguiça gigante era quadrúpede e que se colocava em posição bípede apenas para se alimentar.

Como indicado anteriormente, era intenção do museu que o modelo da preguiça gigante e os elementos existentes ao seu redor pudessem revelar informações como tipo de alimentação, locomoção, ambiente, dentre outros conceitos, o que pôde ser percebido tanto por meio da fala do responsável pelo museu, quanto do conteúdo das imagens e dos textos presentes. Desse modo, é possível afirmar que, no que se referem à intenção, muitos dos aspectos relacionados às características biológicas, ecológicas e do contexto geológico inseridas no eixo conceitual foram alcançadas pelos jovens. 
Já do ponto de vista do eixo processual, a exposição tem a intenção de ser um espaço de contemplação e de transmissão de informações. Por meio dos objetos, imagens e texto e segundo os dados obtidos na entrevista ao responsável, a exposição é potencialmente promotora de questionamentos e de curiosidade pelo tema, e pode estimular debates e levantamento de dúvidas sobre as informações oferecidas.

Percebemos que os jovens, no seu conjunto, observam o objeto e o conjunto expositivo e mais intensamente quatro deles levantaram questões sobre a representação do animal e do ambiente na imagem do painel. Questionaram, durante a visita, sobre como os pesquisadores conseguem reproduzir os animais e seu ambiente, se nunca viram esses animais. Podemos ver tal fato no exemplo da jovem Elisa, quando questiona "Como os cientistas sabem, só por meio dos fósseis, como era o ambiente daquela época" ? enquanto observava o painel pintado com o ambiente em que viveu a preguiça gigante e outros animais.

Ao mesmo tempo em que levantam questões importantes acerca do objeto pedagógico e do conjunto expositivo, os jovens elaboraram, em suas discussões, respostas pertinentes e consistentes sobre as suas próprias questões. Como exemplo, ainda durante a vista, responderam a pergunta citada no parágrafo anterior e concluíram que os pesquisadores do museu estudaram o fóssil encontrado e, por meio dele, fizeram associações com o ambiente até inferirem algumas pistas para a produção do painel. Nesse momento, os jovens estabeleceram relações entre as informações oferecidas pela exposição e seus conhecimentos anteriores, tendo sido o painel o mobilizador dessas articulações. Esse fato revela que as intenções do museu vão ao encontro das interações dos jovens no âmbito do eixo processual, na 
Ana Maria Senac Figueroa

OS OBJETOS NOS MUSEUS DE CIÊNCIAS:

o papel dos modelos pedagógicos na aprendizagem

medida em que levantam questionamentos e dúvidas e sugerem respostas às mesmas.

Por outro lado, outras questões com relação ao eixo processual de aprendizagem foram identificadas, como as discussões sobre a autenticidade do modelo. Ao serem estimulados para refletir sobre se o esqueleto da preguiça gigante era de verdade ou de mentira, durante a visita, os jovens, num primeiro momento expressam ser o objeto "verdadeiro". No entanto, ao longo da visita e observando outros espaços para além daquele estudado por nós, um dos jovens identificou ser o modelo do esqueleto da preguiça gigante um substituto. Essa mudança foi promovida pelo fato de João ter percebido emendas no esqueleto de baleia existente na exposição.

Van-Präet (2003) ressalta que, no caso dos museus de história natural, é conveniente valorizar melhor para os visitantes que nada é "realmente natural" entre os espécimes expostos, sendo os objetos, na verdade, produto de conhecimentos. A seu ver, oferecer informações sobre a autenticidade dos objetos permite enriquecer e prolongar a emoção, além de fornecer um precioso momento para o visitante entrar em contato com o processo de produção da ciência. Van-Präet (2003) ressalta ainda que analisar o uso de modelos e substitutos, em história natural, remete à própria natureza das coleções nas disciplinas que a compõem e ao estatuto dos objetos apresentados nas exposições.

A questão da autenticidade dos modelos é um tema central para os museus e está presente nas ideias que os jovens possuem sobre os objetos existentes nessa instituição. Em nossos dados, verificamos que os jovens abordaram essa temática mesmo antes da visita, como fez Elisa. No entanto, a observação da 
preguiça não os auxiliou a perceber que esta se tratava de um modelo. Isso só foi possível no decorrer da visita, de forma casual, por apenas um dos jovens. Se tal informação tivesse sido fornecida de forma clara e intencional na exposição, poderia auxiliar na compreensão mais ampla sobre o uso dos modelos na ciência e na produção de exposições. E mais, poderia auxiliar a que o visitante não saísse dos museus com dúvidas com relação a esse tema, como aconteceu com nossos jovens.

Neste momento, julgamos necessário retomar a questão de pesquisa sobre a influência dos objetos pedagógicos na aprendizagem e apontamos a necessidade dos museus em explicitar aos visitantes o porquê da utilização dos modelos nas exposições. Se o uso do modelo é tão natural na ciência, segundo Van-Präet (2003), é porque ele faz parte do ambiente de pesquisa dos paleontólogos; de um lado, vários tipos de fossilização assemelham-se a modelos naturais; por outro, os modelos têm um interesse científico para os paleontólogos. Suas dimensões e volumetrias comportam uma parte de informação suficiente para inúmeros estudos. Esse aspecto, ressaltado pelo autor, reforça a importância do museu em abordar o porquê do uso dos modelos nas exposições nos museus.

Por um lado, verificou-se que o modelo da preguiça gigante estimulou o interesse e a motivação, além de diálogo e levantamento de questões por parte dos jovens pesquisados. No entanto, grande parte dos aspectos que compõem os eixos conceitual e processual de aprendizagem pôde ser percebida nos dados, quando os jovens se relacionavam com os demais elementos do conjunto expositivo. Assim sendo, objeto, texto e imagem se complementam para gerar as informações fornecidas pela exposição. Para esse fato, temos como exemplo a fala do jovem João, quando diz que não poderia aprender muito sobre a preguiça gigante só 
observando o modelo do seu esqueleto, demonstrando um grande interesse no painel exposto atrás do objeto e ressaltando a sua importância.

O exemplo da jovem Elisa vem ao encontro das pesquisas de Morrissey (2002), que ressalta que expressar os processos do pensamento e compartilhar as mudanças intelectuais com outras pessoas frente a um objeto pode promover uma oportunidade para adultos e crianças compreenderem como outras pessoas pensam, como lidam com as situações do mundo e o que valorizam. Dessa forma, aprendem novas maneiras de pensar sobre o mundo e sobre as pessoas.

As características do conjunto expositivo somadas àquelas do objeto pedagógico corroboram ainda com o que dizem Leinhardt e Crowley (2002) que as conversas dos visitantes durante a visita às exposições nos museus fazem dos objetos os principais responsáveis pela aprendizagem nesses espaços.

Do ponto de vista dos dois eixos da aprendizagem, percebemos, ainda, que o modelo pedagógico foi útil no que diz respeito à promoção de estímulos na maioria dos jovens. Esses estímulos foram capazes de fazer com que eles expressassem seus conhecimentos prévios, fizessem comparações com os modelos que produziram, bem como lessem os textos e observassem atentamente todo o conjunto expositivo, o que vem confirmar as expectativas e intenções do museu.

Para tal, vale lembrar Borun (2002), quando a autora diz que exposições em museus atuam como um catalisador para a estimulação de conversas entre grupos de visitantes e acrescenta, ainda, que os objetos estimulam conversas envolvendo observações, lembranças, associações e conexões ao conhecimento prévio entre os 
grupos de visitantes. Para ela, o museu é um espaço em que todos os envolvidos numa visita atuam como aprendizes.

Ainda, para Borun (2002), cinco níveis de comportamentos influenciam a aprendizagem diretamente, quais sejam: fazer uma pergunta, comentar ou explicar a exposição, ler o texto explicativo em voz alta e ler em silêncio. Esses comportamentos foram considerados por ela, de acordo com suas pesquisas, indicativos de desempenho de aprendizagem e usados em um de seus estudos. Assim, nossa pesquisa corrobora com a fala da autora, já que os níveis de comportamentos citados acima foram verificados com os jovens pesquisados, compondo aspectos das dimensões do eixo processual de aprendizagem.

É importante ressaltar que nem todos os aspectos relacionados ao eixo processual de aprendizagem foram identificados no processo de produção do modelo final após a visita. Atribuímos esse fato a dois fatores. O primeiro refere-se à metodologia da pesquisa, já que, durante as entrevistas, solicitamos que eles produzissem o esqueleto da preguiça gigante antes e após a visita, o que naturalmente os levou a focalizar mais na reprodução do mesmo em seus aspectos biológicos, com ênfase na estrutura do animal. Além disso, na elaboração de modelos em massa, a representação do contexto ao redor do objeto, ou seja, de todo o conjunto expositivo, pode ter sido prejudicado pela própria natureza do material de modelagem.

O segundo fator que pode explicar o fato de que os aspectos do eixo processual não terem sido tão evidenciados na produção do modelo final pelos jovens está diretamente relacionado à aprendizagem. Isto pode ser atribuído à ênfase na centralidade das características taxonômicas e de percepção dos 
elementos visíveis dos objetos biológicos quando observados por visitantes nos museus. Esse aspecto foi identificado na literatura (TUNNICLIFFE, 1995; GARCIA, 2006), sendo merecedor de mais estudos.

Os questionamentos não respondidos e as concepções errôneas e incompletas também foram percebidos no âmbito dessa pesquisa, o que nos faz repensar as ações sobre os objetos nos museus. Como exemplo, retomamos a fala da jovem Rita quando tenta explicar por que a preguiça gigante foi extinta: "Sabe $o$ que aconteceu com ela? Houve a seleção natural, a de Darwin, onde os bichos tinham que se adaptar ao meio. A partir dessa preguiça gigante é que se deu a origem da preguicinha normal, que nem aquele lance do pescoço da girafa". A jovem saiu do museu com a concepção errônea sobre a extinção da preguiça gigante e sobre a origem das preguiças de hoje. Esse dado reforça a necessidade de se estudar os processos de aprendizagem em museus e as reais potencialidades que os objetos promovem no que se refere à formação de conceitos (BIZERRA, 2009).

Para Morrissey (2002), encontros com objetos, sejam eles do ambiente natural ou cultural, inflamam a curiosidade, a imaginação, as memórias e as perguntas. Fornecem, também, uma oportunidade para o diálogo, a investigação e as conversas nas quais os indivíduos fazem profundas conexões, não somente com o mundo ao seu redor, mas com outros indivíduos que estão em frente ao objeto, com os conteúdos que permeiam o objeto e com os pensamentos e experiências de cada um. Assim, essas conexões ou interações entre os indivíduos de um determinado grupo, na presença de objetos, são a base para a aprendizagem e o núcleo do conceito de museu como sendo lugares onde o conhecimento é construído, discutido, refletido e transmitido a futuras gerações. 
Focalizando as interações citadas acima, e as maneiras como os objetos influenciam a aprendizagem, os museus podem melhor entender e facilitar a experiência do visitante nesses espaços de educação não formal (MORRISSEY, 2002). A autora relata, ainda, que os objetos podem nos levar para uma "viagem" do mundo comum do dia-a-dia para um mundo de desafios e mudanças e, a partir dessa "viagem", voltar para casa uma pessoa diferente daquela que chegou ao museu. Para ela, os objetos nos levam do familiar e conhecido para lugares secretos e distantes, onde ideias são modificadas e para onde várias formas de interpretações nos servem de guia ou orientações.

Em nossa pesquisa, percebemos que, em sua maioria, as intenções do modelo pedagógico foram compreendidas pelos jovens visitantes. Evidenciamos esta conclusão a partir dos elementos que compõem os eixos das dimensões da aprendizagem analisados.

As interações com os objetos nos museus promovem a possibilidade de realizar observação, descrição, de expressar conhecimento prévio, de promover discussão, criação e testagem de hipóteses. Elas ainda promovem a imaginação e a elaboração de questões. No entanto, no que se refere à formação correta de conceitos científicos, pensar a forma de apresentar os objetos, os textos e as imagens nos museus é fundamental. Para tal, o conjunto expositivo que compõe a exposição em que o modelo do esqueleto da preguiça gigante se insere foi adequado para a produção do conhecimento e para as aprendizagens dos jovens, visto que promove uma apresentação complementar ao objeto escolhido. 
É importante finalizar nosso estudo assumindo que muitos ainda são os desafios a serem vencidos para caracterizar a potencialidade dos modelos nos museus, especialmente nos museus de ciências.

Consideramos que esta tese tem como mérito trazer à tona algumas reflexões acerca da influência dos modelos pedagógicos na aprendizagem, especialmente nos espaços de educação não formal, sem a pretensão, entretanto, de esgotá-las. Ressaltamos, principalmente, a possibilidade de realização de mais investigações sobre as intenções dos objetos pedagógicos e das interações dos visitantes em outros espaços e com outros públicos.

Aprender a entender os objetos pedagógicos e como eles interagem com relação à aprendizagem dos jovens foi um desafio instigante e, ao mesmo tempo, demandou um grande esforço, pois ainda há poucas publicações específicas do tema da potencialidade dos objetos pedagógicos como a delineamos nessa pesquisa.

Acreditamos, ainda, que as discussões acerca do tema estudado transcendem o objeto do museu em si mesmo, fato que possibilita maior valorização do caráter social das instituições museais e permite que as relações de ensino e de aprendizagem ocorram nesses espaços também para a promoção da formação de cidadãos. Que os nossos jovens participem ativamente de suas aprendizagens, questionem, discutam e saiam de uma posição passiva para uma posição ativa e interativa ao se relacionarem com os objetos de conhecimento. 
REFERÊNCIAS BIBLIOGRÁFICAS 


\section{REFERÊNCIAS BIBLIOGRÁFICAS}

ALBERTI, Samuel J. J. M. Objects and the museum. ISIS, v. 96, p. 559-571, 2005.

ALLEN, S. Looking for Learning in Visitor Talk: A Methodological Exploration. In: LEINHARDT, G.; CROWLEY, K.; KNUTSON, K. (eds.). Learning Conversations in Museums. Mahwah: Lawrence Erlbaum, 2002. p. 259-303.

ALMEIDA, Adriana Mortara. Desafios da relação museu-escola. Revista Comunicação e Educação da USP, v. 3, n. 10, set./dez. 1997.

ALVES-MAZOTTI, A J. O Método nas Ciências Sociais. In: ALVES-MAZZOTTI, A. J.; GEWANDSZNAJDER, F. O Método nas Ciências Naturais e Sociais: pesquisa quantitativa e qualitativa. São Paulo: Pioneira, 2002.

BEETLESTONE, J. G.; JOHNSON, C. H.; QUIN, M.; WHITE, H. The science center movement: contexts, practice, next challenges. Public Understanding of Science, n. 7, p. 5-26, 1998.

BELLAIGUE, M.; MENU, M. Object-document? Ou: le Voir et le Savoir. In: SYMPOSIUM OBJECT-DOCUMENT. Beijing, China, 1994. ICOFOM Studies Series, 1994, v. 23, p. 143-145.

BIZERRA, A. F. Atividade de Aprendizagem em Museus de Ciências. Tese [Doutorado] - Faculdade de Educação da Universidade de São Paulo, 2009.

BORUM, Minda. Object-Based Learning and Family Groups. In: Gaea Leinhardt, Kevin Crowley y Karen Knutson, (eds.) Learning Conversations in Museums. New Jersey: Lawrence Erlbaum Associates, Publishers, 2002.

BORUN, M.; CHAMBERS, M. B.; DRITSAS, J.; JOHNSON, J. I. Enhancing Family Learning Through Exhibits. Curator: The Museum Journal, v. 40, p. 279-295, 1997.

BURCAW, G. Introduction to museum work. Nashville (TN): AASLH Press, 1983.

CAREY, S. Conceptual change in childhood. Cambridge (MA): MIT Press, 1985.

CARR, David. Aliance against compromise. Museum News, v. 79, n. 2, p. 29-31, 6263, March/April 2000.

CAZELLI, S. et al. Educação e comunicação em museus de ciência: aspectos históricos, pesquisa e prática. In: GOUVÊA, G., MARANDINO, M., LEAL, M. C. [Orgs.]. Educação e Museu: A Construção Social do Caráter Educativo dos Museus de Ciências. Rio de Janeiro: Access, 2003. p. 83-106. 
CAZELLI, S. et al. Tendências Pedagógicas das Exposições de um Museu de Ciência. In: ENCONTRO NACIONAL DE PESQUISA EM EDUCAÇÃO EM CIÊNCIAS, 2., 1999. Atas do Valinhos, São Paulo, set. 1999.

CAZELLI, S.; GOUVÊA, G.; FRANCO, C.; SOUSA, C. N. Padrões de Interação e Aprendizagem Compartilhada na Exposição Laboratório de Astronomia. Revista Brasileira de Estudos Pedagógicos, Brasília, v. 78, n. 188-190, p. 413-471, jan./dez. 1997.

COLINVAUX, Dominique. Museus de ciências e psicologia: interatividade, experimentação e contexto. História, Ciências, Saúde, Manguinhos, v. 12, suplemento, p. 79-91, 2005.

DAUSTER, T. Relativização e Educação: Usos da Antropologia na Educação. In: ENCONTRO ANUAL DA ANPOCS, GT de Educação e Sociedade, 13., 1989. Resumos... Caxambu: 1989.

DEAN, D. Museum Exhibition: Theory and Practice. London Routledge, 1994.

DELOCHE, Bernard. Le muse virtuel. Paris: PUF, 2001, 265 p. In: VAN-PRÄET, Michel. A educação no Museu, divulgar "Saberes Verdadeiros" com "Coisas Falsas? In: GOUVÊA, G; MARANDINO, M.; LEAL, M. C. (org.) Educação e Museu: a construção do caráter educativo dos museus de ciências. Rio de Janeiro: FAPERJ: Access, 2003.

DEWEY, J. Psychology and social practice. Psychological review, Washington, $\mathrm{n}$. $7,1900$.

DIERKING, L. D. Lições sem limite: como o aprendizado por livre escolha vem transformando a educação em ciência e tecnologia. História, Ciências, Saúde, Manguinhos, v. 12 (suplemento), p. 145-60, 2005.

DIERKING, L. The role of context in children's learning from objects and experiences. In: PARIS, S. G. (Ed.) Perspectives on Object-Centered Learning in Museums. Mahwah, NJ: Lawrence Erlbaum Associates, Inc., 3-18, 2002.

DRIVER, R.; EASLEY, J. Pupils and paradigms: A review of literature related to concept development in adolescent science students. Studies in Science Education, v. 12, p. 7-15, 1978.

DUIT, R.; GLYNN, S. Mental modelling. In: WELFORD, G.; OSBORNE, J.; SCOTT, P. (Eds.) Research in Science Education in Europe. London: Falmer, 1996.

FALCÃO, D. Padrões de Interação e Aprendizagem em Museus de Ciência. 1999. Tese (Mestrado em Educação, Gestão e Difusão em Biociências) Departamento de Bioquímica Médica do Instituto de Ciências Biomédicas da UFRJ, Rio de Janeiro, 1999.

FALCÃO, D. A Interatividade nos Museus de Ciências. In: REUNIÃO DA RED-POP, 6., 1999. Anais... Rio de Janeiro: Museu de Astronomia e Ciências Afins/UNESCO, jun. 1999. 
FALCÃO, D.; ALVES, F.; COLINVAUX, D. Museus de Ciências, Aprendizagem e Modelos Mentais; Identificando Relações In: GOUVÊA, G.; MARANDINO, M.; LEAL, M. C. [Orgs.] Educação e Museu: A Construção Social do Caráter Educativo dos Museus de Ciências. Rio de Janeiro: FAPERJ/Access Editora. 2003. P. 185-206.

FALCÃO, D.; COLINVAUX, D.; KRAPAS, S.; QUEIROZ, G.; ALVES, F.; CAZELI, S.; VALENTE, E. A model-based approach to science exhibition evaluation: A case study in a Brazilian astronomy museum. International Journal of Science Education, England, v. 26, n. 8, 2004.

FALK, J. Free-choice Science Learning: Framing the Discussion. In: FALK, J. (ed.). Free-Choice Science Education: How we Learn Science Outside the School. Teachers College, Columbia University, 2001.p. 3-20.

FALK, J. H. The contribution of free-choice learning to public understanding of science. Interciencia, v. 27, p. 62-65, 2002.

FALK, J. H.; DIERKING, L. D. Learning from museums visitors experiences and the making of meaning. Walnut Creek (CA): Altamira Press, 2000.

FALK, J. H.; DIERKING, L. D. Lessons Without Limit: how free-choice learning is transforming education. Walnut Creek (CA): Altamira Press, 2002.

FALK, J. H.; DIERKING, L. D. Public institutions for personal learning: establishing a research agenda. Washington, DC: American Association of Museums, 1995.

FALK, J. H.; DIERKING, L. D. The Museum Experience. Washington, DC: Whalesbak Books, 1992.

FALK, J. The director's cut: Toward an improved understanding of learning from museums. Science Education, v. 88, n. 1, 2004.

FALK, John. Museums as Institutions for Personal Learning. Daedalus, v. 128, n. 3, 1999.

FIGUEROA, Ana Maria Senac. O uso sistemático de analogias: estudo de um modelo de ensino para o conceito de incompatibilidade sanguínea. 139p. 2004. Dissertação (Mestrado em Tecnologia) - Centro Federal de Educação Tecnológica de Minas Gerais, Belo Horizonte, 2004.

GARCIA, Viviane A. R. O processo de aprendizagem no zôo de Sorocaba: Análise da atividade educativa visita orientada a partir dos objetos biológicos. $224 \mathrm{p}$. 2006. Dissertação (Mestrado em Educação) - Faculdade de Educação, Universidade São Paulo, São Paulo, 2006.

GARCIA, Viviane A. R. Objetos que ensinam. REUNIÓN DE LA RED DE POPULARIZACIÓN DE LA CIENCIA Y LA TECNOLOGÍA EN AMÉRICA LATINA Y EL CARIBE (RED POP - UNESCO), 10, 2007. Anais... San José: Red Pop, mayo 2007. 
GARDNER, Howard. The Unschooled Mind: How Children Think and How Schools Should Teach. New York: Basic Books, 1991.

GASPAR, A. Museus e Centros de Ciências: Conceituação e Proposta de um Referencial Teórico. 1993. Tese (Doutorado) - Faculdade de Educação da USP, São Paulo, 1993.

GENTNER, D.; STEVENS, A. L. Mental Models. Hillsdale (NJ): Lawrence Erlbaum, 1983.

GILBERT, J. K. The interface between Science Education and Technology Education. International Journal of Science Education, v. 14, n. 5, p. 563-578, 1992.

GILBERT, J.; BOULTER, C. Aprendendo ciências através de modelos e modelagem. In: COLINVAUX, D. (Org.). Modelos e educação em ciências. Rio de Janeiro: Ravil, 1998.

GILBERT, J.; PRIEST, M. Models and discourse: a primary school science class visit to a museum. Science Education, v. 81, n. 6, p. 749-762, 1997.

HEIN, George. Learning in the Museum. London: Routledge. 1998.

HEIN, George. The Constructivist Museum. Journal of Education in Museums, v. $16,1995$.

HEIN, H. The Museum in Transition: A Philosophical Perspective. Washington: Smithsonian Institution, 2000.

HOOPER-GREENHILL, Eilean. Education, communication and interpretation: towards a critical pedagogy in museums. In: HOOPER-GREENHILL, E. (Org.). The Educational role of The Museum. London: Routledge, 1994a. p. 3-25.

HOOPER-GREENHILL, Eilean. Education, communications and interpretations: towards a critical pedagogy in museums. In: HOOPER-GREENHILL, E. (Org.). The Educational Role of the Museum. $2^{\text {nd }} \mathrm{ed}$. London: Routledge, 1999. 346p.

HOOPER-GREENHILL, Eilean. Learning in Art Museums: Strategies of Interpretation, in Testing the Water. Liverpool, Liverpool University Press, 2000.

HOOPER-GREENHILL, Eilean. Museum learners as active postmodernists: contextualizing constructivism. In: HOOPER-GREENHILL, E. (Org.). The Educational role of The Museum. Routledge, London, 1994b. p. 67-72.

IANINI, A. M. N.; MARANDINO, M.; BIZERRA, A.; CONTIER, D. Pesquisa em divulgação científica: um levantamento de referenciais teóricos nacionais. In: ENCONTRO NACIONAL DE PESQUISA EM EDUCAÇÃO EM CIÊNCIAS, 6., 2007. Caderno de resumos. Florianópolis: VI ENPEC, 2007.

KAPRAS, S. et al. Modelos: uma análise de sentidos na literatura de pesquisa em ensino de ciências. Revista Investigação no Ensino de Ciências, 1997. Disponível 
em: <http://www.if.ufrgs.br/ienci/artigos/Artigo_ID33/v2_n3_a1997.pdf>. Acesso em: 12 out. 2008.

LEINHARDT, G. Talking to oneself: Diaries of museum visits. In: LEINHARDT G., CROWLEY, K.; KNUTSON, K. (Eds.). Learning conversations in museums. Mahwah, NJ, Lawrence Erlbaum Associates, 2002.

LEINHARDT, G.; CROWLEY, K. Objects of learning, objects of talk: changing minds in museums. In: PARIS, S. (ed). Multiple perspectives on children's objectcentered learning. Mahwah, NJ: Lawrence Erlbaum Associates, 2002. Disponível em: <http://mlc.Irdc.pitt.edu/leinhardtcrowley.pdf>. Acesso em: maio 2011.

LEINHARDT, G.; CROWLEY, K.; KNUTSON, K. (Eds.). Learning conversations in museums. Mahwah, NJ: Lawrence Erlbaum, 2002.

LESSA, G.; CARTELLE, C.; FARIA, H. D.; GONÇALVES, P. R. Novos Achados de Mamíferos Carnívoros do Pleistoceno Final: Holoceno em Grutas Calcárias do Estado da Bahia. Acta Geológica Leopoldensia, v. 21, n. 46/47, p. 157-169,1998.

LOUREIRO, M. L. N. M. Fragmentos, modelos, imagens: processos de musealização nos domínios da ciência. Datagramazero, Revista de Ciência da Informação, v. 8, n. 2, 2007. Disponível em: <http://www.dgz.org.br/abr07/ F_I_art.htm>. Acesso em: 17 abr. 2009.

LOURENÇO, M. Museus de Ciência e Técnica: que objectos? 2000. Dissertação (Mestrado em Museologia e Patrimônio) - Departamento de Antropologia, Faculdade de Ciências Sociais e Humanas, Universidade Nova de Lisboa, Lisboa, 2000.

MARANDINO, M. A pesquisa educacional e a produção de saberes nos museus de ciências. História, Ciência, Saúde, Manguinhos, v. 12, (suplemento), p. 161-181, 2005.

MARANDINO, M. et al. A abordagem qualitativa nas pesquisas em educação em museus. ENCONTRO NACIONAL DE PESQUISA EM EDUCAÇÃO EM CIÊNCIAS, 7., 2009. Anais... Florianópolis, 2009.

MARANDINO, M. Interfaces na relação museu-escola. Cad. Cat. Ens. Fís., v. 18, n. 1, abr. 2001.

MARANDINO, M. Museus de Ciências, Coleções e Educação: relações necessárias. Revista Museologia e Patrimônio, v. 2, n. 2, 2009.

MARANDINO, M. O conhecimento biológico nas exposições de museus de ciências: análise do processo de construção do discurso expositivo. 2001. 434f. Tese (Doutorado) - Faculdade de Educação da USP, São Paulo, 2001.

MARANDINO, M. Perspectivas da pesquisa educacional em museus de ciências. In: SANTOS, F. M. T; GRECA, I. M. (Orgs.). A pesquisa em ensino de ciências no Brasil e suas metodologias. ljuí: UNIJUÍ, 2006. p. 89-122. 
MARANDINO, M.; GOUVÊA, G.; AMARAL, D. P. A Ciência, o brincar e os espaços não-formais de educação. REUNIÃO ANUAL DA ANPED, GT DE DIDÁTICA, 21., 1998. Atas... Caxambu: ANPED, 1998.

MARTINS, H. H. T. S. Metodologia Qualitativa de Pesquisa. Educação e Pesquisa, São Paulo, v. 30, n. 2, maio/ago 2004.

MINAYO, Maria Cecília de Souza. O desafio do conhecimento científico: pesquisa qualitativa em saúde. 2. ed. São Paulo/Rio de Janeiro: Hucitec-Abrasco, 1993.

MORRISSEY, K. Pathways Among Objects and Museum Visitors. In: PARIS, S. (eds.) Perspectives on Object-Centered Learning in Museums. Mahwah: Lawrence Erlbaum Associates. 2002. p. 285-299.

MORTIMER, E. F. Construtivismo, Mudança conceitual e ensino de ciências: Para onde vamos?. Investigação em Ensino de Ciências, v.1, n.·1, abril de 1996.

MORTIMER, E. F.; Linguagem e Formação de Conceitos no Ensino de Ciências, ed. UFMG: Belo Horizonte, 2000.

MORTON, Alan. Curatorial challenges: contexts, controversies and things. Here and now. Contemporary science and technology in museums and science centres. Londres: Science Museum, 1997.

MOYA, M. C. H. Cómo Hacer un Museo de Ciencias. Mexico: Ediciones Científicas Universitarias, 1998.

MURRIELLO et al. Challenges of an exhibit on nanoscience and nanotechnology. Journal of Science Communication, v. 5, 2006.

NAGEM, R. L.; CARVALHAES, D. O.; DIAS, J. A. Y. Uma proposta de metodologia de ensino com analogias. Revista Portuguesa de Educação, v. 2, n. 14, 2001.

NASCIMENTO, S. S. O desafio de construção de uma nova prática educativa para os museu. In: FIGUEIREDO, B.; VIDAL, D. (org). Museus: dos gabinetes de curiosidades ao Museu Moderno. Belo Horizonte: Argumentum, CNPq. 2005. p. 221-239.

NORMAN, D. Some observations on Mental Models. In: GENTNER, Dedre; STEVENS, Albert L. Mental Models. New York: Bolt Beranek and Newman Inc. Lawrence Erlbaum associates, Publishers Hillsdale, 1983.

NORMAN, D. Things that make us smart: Defending Human Attributes in the Age of the Machine. Cambridge: Perseus Books, 1993.

NORMAN, D. Twelve Issues for cognitive science. Cognitive science, v. 4, p. 1-32, 1980.

PARIS, S. (Ed.). Perspectives on object-centered learning in museums. London: Lawrence Erlbaum Associates, 2002. 
PARIS, S.; ASH, D. Reciprocal Theory Building Inside and Outside Museums. Curator, Lanham, v. 43, n. 3, p. 199-210, jul. 2000.

PEARCE, Susan M. Museums, Objects and Collections: A Cultural Study. Washington, D.C.: Smithsonian Institution Press, 1992.

PEREIRA, J. S.; SIMAN, L. M. C.; COSTA, C. M.; NASCIMENTO, S. S. Escola e Museus: diálogos e práticas. Belo Horizonte: Secretaria de Estado de Cultura/Superintendência de Museus; PUC-Minas/Cefor, 2007.

PIAGET, J. Seis estudos de psicologia. Rio de Janeiro: Forense-Universitária, 1980.

PINTÓ, R.; ALIBERAS, J.; GÓMEZ, R. Tres enfoques de la investigación sobre concepciones alternativas. Enseñanza de las Ciencias, v. 14, n. 2, 1996.

PUCHNER, L.; RAPOPORT, R.; GASKINS, S. Learning in Children's Museums: Is It Really Happening? Curator, Lanham, v. 44, n. 3, p. 237-259, jul. 2001.

REBELLO, L. O perfil educativo dos museus de ciência da cidade do Rio de Janeiro. 2001. Dissertação (Mestrado) - Universidade Federal Fluminense, 2001.

ROWE, S. The role of objects in Active, Distributed Meaning-Making. In: PARIS, Scott G. Perspectives on object-centered learning in museums. London: Lawrence Erlbaum Associates, Inc., 2002.

RUIZ, M. C. Investigación cualitativa em museos de ciências. A propósito de uma exposición sobre Albert Einstein. Museolúdica, Facultad de Ciencias, Universidad Nacional de Colômbia, v. 8, n. 14-15, 2005.

SANTOS, B. de S. Um discurso sobre as Ciências na transição para uma ciência pós-Moderna. Estudos Avançados, v. 2, n. 2, maio-ago. 1988.

SILVERSTONE, Roger. The medium is the museum: on object logics in times and spaces. In: DURANT, John (ed.) Museums and the public understanding of science. Londres: Science Museum, 1992.

STUDART, D. C. The perceptions and behaviour of children and their families in child-orientated museum exhibitions. Thesis $(\mathrm{PhD})$ - Department of Museum and Heritage Studies, University College, London, 2000.

StUdART, D. C.; ALMEIDA, A. M.; VALENTE, M. E. A. Pesquisa de Público em Museus: desenvolvimento e perspectivas. In: GOUVÊA, G; MARANDINO, M; LEAL, M. C.. (Org.). Educação e Museu: a construção social do caráter educativo dos museus de ciência. Rio de Janeiro: Access, 2003.

TRIVINÖS, A. N. S. Introdução à pesquisa em ciências sociais: a pesquisaqualitativa em educação: São Paulo: Atlas, 1987, p. 116-174. 
TUNNICLIFFE, S. D. A comparison of conversations of primary school groups at animated, preserved and live animal specimens. Journal of Biological Education, v. 30, n. 3, p. 1-12, 1996.

TUNNICLIFFE, S. D. Conversations within primary school parties visiting animal specimens in a museum and zoo. Journal of Biological Education, v. 30, n. 2, p. 130-141, 1996.

TUNNICLIFFE, S. D. Live Animals as Exhibits. Journal of the International Association of Zoo Educators, 12ํㅡ IZE Congress, Los Angeles, p. 34-40, 1995.

VALENTE, M. E.; CAZELLI, S.; ALVES, F. Museos, ciência e educação: novos desafíos. História, Ciência, Saúde, Manguinhos, v. 12, 2005. (Museus e Ciências. Suplemento).

VAN-PRÄET, M.; POUCET, B. Les Musées, lieux de contre-éducation et de partenariat avec l'école. Education et Pédagogie, n. 16, p. 1-7, 1992.

VAN-PRÄET, Michel. A educação no Museu, divulgar "Saberes Verdadeiros" com "Coisas Falsas"? In: GOUVÊA, G.; MARANDINO, M.; LEAL, M. C. (org.) Educação e Museu: a construção do caráter educativo dos museus de ciências. Rio de Janeiro: FAPERJ, Access, 2003.

WITCOMB, Andrea. The end of the Mausoleum: museums in the age of electronic communication. Museums and the Web 97. Selected papers. Pittsburgh: Archive Museum Informatics, 1997. 
APÊNDICES 


\section{APÊNDICE A - ROTEIRO DA ENTREVISTA COM O RESPONSÁVEL PELA CONFECÇÃO E EXPOSIÇÃO DO ESQUELETO DA PREGUIÇA GIGANTE}

DOUTORADO EM EDUCAÇÃO

LINHA DE PESQUISA: ENSINO DE CIÊNCIAS E MATEMÁTICA

ALUNA: ANA MARIA SENAC FIGUEROA

ORIENTADORA: $\operatorname{Prof}^{\mathrm{a}}{ }^{\mathrm{D}} \mathrm{r}^{\mathrm{a}} \mathrm{M} A R T H A$ MARANDINO

1. NOME DA INSTITUIÇÃO:

2. NOME DO OBJETO PESQUISADO:

3. FORMAÇÃO:

4. CARGo Que ocupa no museu:

5. FOI VOCÊ QUE IDEALIZOU ESTE OBJETO?

6. O QUE O LEVOU A CRIAR E CONSTRUIR ESSE OBJETO?

7. POR QUE ESSE OBJETO ESTÁ INSERIDO NESTA EXPOSIÇÃO?

8. O QUE ELE REPRESENTA PARA ESSA EXPOSIÇÃO?

9. O QUE VOCÊS PRETENDEM QUE ESSE OBJETO TRANSMITA AO PÚBLICO?

10. QUE MENSAGEM?

11. QUe CONCEITOS CIENTíFICOS?

12. QUAIS FORAM AS ETAPAS PARA A INSERÇÃO DESSE OBJETO NA EXPOSIÇÃO?

13. PESQUISA-CONSERVAÇÃO-DOCUMENTAÇÃO-EXPOSIÇÃO-EdUCAÇÃO

14. POR QUE ESSE TEMA FOI ESCOLHIDO? 
Ana Maria Senac Figueroa

OS OBJETOS NOS MUSEUS DE CIÊNCIAS:

o papel dos modelos pedagógicos na aprendizagem

15. PRÁ QUE TIPO DE PÚBLICO?

16. QUAIS FORAM OS MATERIAIS UTILIZADOS PARA A CONSTRUÇÃO DESSE OBJETO?

17. DE QUE TRATA A EXPOSIÇÃO? QUAL É O SEU TEMA?

18. POR QUE ESTE TEMA FOI ESCOLHIDO?

19. COMO FOI ESCOLHIDO O ESPAÇO EXPOSITIVO? QUAIS SÃO AS CARACTERÍSTICAS DESTE ESPAÇO?

20. Que tiPOS DE LINGUAGENS DE APOIO FORAM PENSADAS PARA ESSE OBJETO (TEXTOS, ETIQUETAS, PAINÉIS, ILUSTRAÇÕES, RECURSOS GRÁFICOS, ELETRÔNICOS ETC.)?

21. COMO FOI ELABORADO O DISCURSO EXPOSITIVO? QUAIS AS CARACTERÍSTICAS DOS TEXTOS ELABORADOS PARA ESSE OBJETO?

22. QUAL SERIA A PROPOSTA CONCEITUAL DA EXPOSIÇÃO?

23. COMO ESTA PROPOSTA FOI ELABORADA?

24. Foram REALIZADAS PESQUISAS PRÉVIAS SOBRE A TEMÁTICA DA EXPOSIÇÃO? DE QUE TIPO? REALIZOU-SE LEVANTAMENTO BIBLIOGRÁFICO? FORAM FEITAS CONSULTAS A ESPECIALISTAS?

25. COMO FORAM ESCOLHIDOS OS CONTEÚDOS E CONCEITOS ABORDADOS NA EXPOSIÇÃO? POR QUÊ?

26. COMO SE dÁ A RELAÇÃO ENTRE AS PESQUISAS EXISTENTES SOBRE O CONHECIMENTO E A SUA APRESENTAÇÃO NA EXPOSIÇÃO?

27. ESTÃO PRESENTES NA EXPOSIÇÃO TEMAS OU CONCEITOS CIENTíFICOS ATUAIS? POR QUÊ?

28. VOCÊ CONSIDERA A EXPOSIÇÃO ATUAL, DO PONTO DE VISTA CIENTÍFICO? POR QUÊ?

29. FORAM PERCEBIDAS DIFICULDADES NA APRESENTAÇÃO DE ALGUM DOS TEMAS ABORDADOS NA EXPOSIÇÃO? POR QUÊ?

30. EM RELAÇÃO AO PONTO DE VISTA MUSEOGRÁFICO, COMO VOCÊ PERCEBE A ATUALIDADE DESTE OBJETO NA EXPOSIÇÃO?

31. EM SUA OPINIÃO, O PÚBLICO COMPREENDE A PROPOSTA CONCEITUAL QUE ESSE OBJETO QUER TRANSMITIR? 
Ana Maria Senac Figueroa

OS OBJETOS NOS MUSEUS DE CIÊNCIAS:

o papel dos modelos pedagógicos na aprendizagem

32. VoCÊ TEM ALGUM TIPO DE AVALIAÇÃO DO PÚBLICO COM RELAÇÃO A ESSE OBJETO? QUAIS SÃO ELES?

33. QUAIS SÃO, EM SUA OPINIÃO, OS PONTOS POSITIVOS, OS ELEMENTOS FORTES DESSE OBJETO EM ESPECIAL? POR QUÊ?

34. EM QUE ASPECTOS QUE VOCÊ O CONSIDERA FRÁGIL? POR QUÊ?

35. VOCÊ PROPORIA ALGUM TIPO DE MODIFICAÇÃO NA EXPOSIÇÃO? POR QUÊ?

36. EM SUA OPINIÃO, O PÚBLICO APRENDE OS CONCEITOS TRATADOS NA EXPOSIÇÃO? POR QUÊ? 


\section{APÊNDICE B - ENTREVISTA COM OS JOVENS ANTES DA VISITA AO Museu de Ciências Naturais DA PUC-MINAS}

1. Você já esteve em um museu de ciências naturais? $\square$ sim $\square$ não

Se sim, responda as questões 2, 3, 4, 5 e 6. Se não, vá diretamente para a pergunta 7:

2. Escreva o(s) nome(s) do(s) museu(s) de ciências naturais visitado(s):

3. Do que você gostou no(s) museu(s)? Por quê?

4. Do que você não gostou no(s) museu(s)? Por quê? 
Ana Maria Senac Figueroa

OS OBJETOS NOS MUSEUS DE CIÊNCIAS:

o papel dos modelos pedagógicos na aprendizagem

5. O que você aprendeu no(s) museu(s) visitado(s)? Justifique a sua resposta.

Que objetos da(s) exposição(s) que você já visitou chamaram mais a sua atenção? Cite pelo menos 03 objetos. Explique por que eles chamaram a sua atenção.

7. Nós vamos visitar o museu da PUC-MINAS. Você já o conhece? $\square$ sim não

a. Se não, o que você espera encontrar? Que tipo de objetos você acha que existe nas exposições desse museu? 
Ana Maria Senac Figueroa

OS OBJETOS NOS MUSEUS DE CIÊNCIAS:

o papel dos modelos pedagógicos na aprendizagem

b. Se você já o conhece, que objeto the chamou mais a atenção? Justifique.

8. Você considera que todos os objetos existentes no museu da PUC-MINAS são de verdade? Justifique a sua resposta.

9. Para você, qual a importância de visitar um museu de ciências naturais, como o da PUC-MINAS? Justifique a sua resposta. 


\section{APÊNDICE C - CONSTRUINDO O MODELO DO ESQUELETO DA PREGUIÇA GIGANTE - PRÉ-VISITA}

INICIAIS DO NOME:

Série: $3^{\circ}$ ano do Ensino Médio

\section{Responda:}

Você já viu uma foto ou desenho de uma preguiça gigante? $\square \operatorname{sim} \square$ não Escreva, nas linhas em branco, como você acredita ser a preguiça gigante:

Escreva, em poucas linhas, o que você sabe sobre a importância que desse animal para o planeta, há 11 mil anos.

Descreva o ambiente em que viva a preguiça gigante há 11 mil anos. 
Ana Maria Senac Figueroa

OS OBJETOS NOS MUSEUS DE CIÊNCIAS:

o papel dos modelos pedagógicos na aprendizagem

Procedimento:

Material: massinha de modelar

Desenvolvimento da atividade: agora, você vai construir um modelo de como você acredita ser uma preguiça gigante.

2.1. Faça, no espaço abaixo, um desenho do que você acredita ser a preguiça gigante, antes de iniciar a construção do modelo:

2.2. Cole aqui a foto do modelo da preguiça gigante que você construiu com a massinha de modelar: 


\section{APÊNDICE D - QUESTÕES UTILIZADAS PELA PESQUISADORA DURANTE A VISITA AO MUSEU, COM OS ALUNOS FRENTE AO OBJETO ESCOLHIDO - O ESQUELETO DA PREGUIÇA GIGANTE}

\section{PLACAS}

1. Esse esqueleto é de verdade ou de mentira?

2. O que vocês acham que estão aprendendo em frente ao esqueleto da preguiça gigante?

3. Esse animal foi bípede ou quadrúpede?

4. Leiam o texto que está ao lado do esqueleto.

5. O que diz o texto?

6. Por que você acha que colocaram esse esqueleto no museu?

7. Você acha que se esse esqueleto estivesse num outro lugar ele teria os mesmos propósitos? 


\section{APÊNDICE E - ENTREVISTA PÓS-VISITA AO MUSEU DA PUC-MINAS COM OS JOVENS}

CONSTRUINDO MODELOS APÓS A VISITA AO MUSEU

Iniciais do seu Nome:

Série: $3^{\circ}$ ano do Ensino Médio

Responda:

Você gostou do museu da PUC-Minas? Justifique a sua resposta.

O que você aprendeu sobre a preguiça gigante quando esteve em frente ao esqueleto dela? 
Ana Maria Senac Figueroa

OS OBJETOS NOS MUSEUS DE CIÊNCIAS:

o papel dos modelos pedagógicos na aprendizagem

Agora, você já sabe que o esqueleto da preguiça é uma réplica, um modelo. Você acha que, se no museu estivesse o fóssil original, você teria aprendido mais sobre ele? Justifique a sua resposta.

Descreva o que você, a partir do modelo, descobriu sobre os hábitos alimentares da preguiça gigante, o ambiente em que ela viveu, a importância que ela teve para a formação do ambiente nos dias de hoje.

Agora, após a visita ao museu, reconstrua o modelo de acordo com o que você se lembra do esqueleto da preguiça gigante. Se precisar, Ihe mostraremos uma foto do esqueleto tal qual ele se apresenta no museu. 
Ana Maria Senac Figueroa

OS OBJETOS NOS MUSEUS DE CIÊNCIAS:

o papel dos modelos pedagógicos na aprendizagem

Cole aqui a foto do seu modelo após a visita ao museu. 